\title{
Potato soil-borne diseases. A review
}

\author{
Marie Fiers • Véronique Edel-Hermann • \\ Catherine Chatot • Yves Le Hingrat • \\ Claude Alabouvette $\cdot$ Christian Steinberg
}

Accepted: 15 October 2010 / Published online: 24 June 2011

(C) INRA and Springer Science+Business Media B.V. 2011

\begin{abstract}
Potato crop is the fourth main food crop in the world and it will certainly feed a big part of the global population in the next years. The economical outlets for this crop are great; however, numerous diseases either soil- or airborne can cause huge losses in the production. Worldwide, about 40 soil-borne diseases affect potato and cause severe damages especially on tubers, the economically most important part of the plant. The occurrence and development of soilborne diseases depend on very diverse factors affecting either the pathogen or the plant. Favorable conditions for potato diseases development are frequently the same as the conditions needed for potato growth: temperature between $10^{\circ} \mathrm{C}$ and $25^{\circ} \mathrm{C}$, high humidity, medium $\mathrm{pH}$, etc. Adapted cultural practices such as a rotation longer than 4 years, appropriate fertilization and water management, an adapted delay between
\end{abstract}

M. Fiers $\cdot$ V. Edel-Hermann $\cdot$ C. Alabouvette $\cdot$ C. Steinberg $(\square)$ INRA, Université de Bourgogne UMR 1229 Microbiologie du Sol et de l'Environnement, CMSE,

17 rue Sully, BP 86510, 21065 Dijon cedex, France

e-mail: christian.steinberg@dijon.inra.fr

V. Edel-Hermann

e-mail: veronique.edel@dijon.inra.fr

C. Alabouvette

e-mail: c.ala@agrene.fr

M. Fiers $\cdot$ C. Chatot

Germicopa R\&D, Kerguivarch,

29520 Châteauneuf du Faou, France

C. Chatot

e-mail: catherine.chatot@germicopa.fr

M. Fiers

Bretagne Plants, Roudouhir,

29460 Hanvec, France

e-mail: mariefiers@hotmail.com

Y. Le Hingrat

Bretagne Plants, FNPPPT, Roudouhir,

29460 Hanvec, France

e-mail: yves.lehingrat@fnpppt.fr haulm killing and harvest, and dry and cool conditions for tuber storage are good ways to control potato diseases. In most cases, potato pathogens develop specific survival forms, dissemination ways and host penetration methods. The genetic variability of the pathogens implies the use of adapted diagnostic and control methods. Decision support systems developed to predict yield losses allow choosing good control methods such as the use of healthy seeds, adapted pesticides, cultural practices, and biological control agents for each potato disease. The complexity of the interactions between a pathogen and its host, influenced by biotic and abiotic factors of the environment, make the control of the diseases often very difficult. However, deep knowledge of pathosystems allows setting up integrated pest management systems allowing the production of healthy and good quality potatoes.

Keywords Cultural practices - Decision support system . Pathogen ecology · Pedologic and climatic factors · Plant microorganism interaction $\cdot$ Soil $\cdot$ Soil suppressiveness

\section{Contents}

Introduction. . . . . . . . . . . . . . . . .

I. Effects of abiotic factors on the occurrence and development of soil-borne potato diseases . . . . . 10

I. 1. Soil temperature . . . . . . . . . . . . 10

I. 2. Soil moisture . . . . . . . . . . . . . 13

I. 3. Soil texture . . . . . . . . . . . . . . . . 14

I. 4. Soil $\mathrm{pH} \ldots \ldots \ldots \ldots \ldots \ldots \ldots \ldots \ldots \ldots$. . . . . . . . . . . . .

I. 5. Soil organic matter . . . . . . . . . . . . 17

II. Effects of biotic factors on the occurrence and development of soil-borne potato diseases . . . . . 18

II. 1. Autecology of pathogens . . . . . . . . . . . . 18 1. 1. Inoculum sources, survival and dissemination pathways ........................18 1. 2. Relationship between inoculum density and disease severity . . . . . . . . . . . . . 22 
1. 3. Mechanisms of infection ............ 22

1. 4. Genetic variability . . . . . . . . . . . . . 28

1. 5. Diagnosis and detection methods . . . . . 28

II. 2. Interactions between microorganisms, organisms and pathogens . . . . . . . . . . . 30

II. 3. Interactions between plants and pathogens . . . 34

III. Effects of cultural practices on the occurrence and development of soil-borne potato diseases . . . . . 35

III. 1. Rotations . . . . . . . . . . . . . . . . . . . . 36

III. 2. Fertilization and amendments . . . . . . . 36

III. 3. Tillage management . . . . . . . . . . . . . . 41

III. 4. Planting, haulm destruction, lifting and harvesting

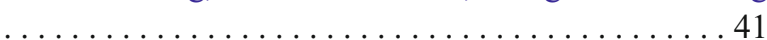

III. 5. Pesticides . . . . . . . . . . . . . . . . . . . . 42

III. 6. Organic farming versus conventional agriculture

. . . . . . . . . . . . . . . . . . . . . . 42

III. 7. Handling and storage . . . . . . . . . . . . 43

IV. Disease management . . . . . . . . . . . . . 43

IV. 1. Risk assessment and decision support systems . .

. . . . . . . . . . . . . . . . . . . . . . . . 44 44

IV. 2. Control methods . . . . . . . . . . . . . . 47

Conclusions . . . . . . . . . . . . . . . . . . 50

References ........................ 52

\section{Introduction}

Potato crop, the world's number one non-grain food commodity, is the fourth main food crop in the world after maize, rice and wheat, with 325 million tons produced in 2007. Potatoes are grown in more than 100 countries, mainly in Asia (135 million tons) and Europe (130 million tons; FAO 2008). They have good gustative and nutritional qualities and can be grown under various climates. This is the reason why Food and Agriculture Organization (FAO) has declared the year 2008 the international year of the potato. Indeed, potato can help fulfill the first United Nations Organization's (UNO) millennium development goal that aims at eradicating extreme poverty and hunger in the world. However, potato (Solanum tuberosum) crop can suffer more than 40 pests and diseases caused by insects, nematodes, viruses, bacteria, and fungi. Those pathogens are air- or soil-borne and cause damages on all parts of the plant. In this review, we will focus on soil-borne fungi, bacteria, and nematodes (Table 1, Fig. 1).

Indeed, diseases caused by viruses or viroïds provoke generally foliar symptoms: leaf distortion, mosaic, crinkling, leaf and vein necroses, dwarfing. and leaf rolling. Only some viruses - tobacco rattle virus (TRV), potato mop-top virus, potato virus $\mathrm{Y}$, and tobacco necrosis virus-can cause damages on tubers such as blemishes or rots in tuber flesh (Table 1). They will be briefly mentioned in Table 1 as well as the vectors (aphids, fungi, or nematodes) involved in their transmission but they will not be detailed in this review.

Soil-borne diseases affecting potato crop can be divided into two groups depending on symptoms: symptoms damaging tubers and those damaging other parts of the plant (Gudmestad et al. 2007).

Diseases affecting stems or roots affect the crop development and may lead to a reduction of the yield (Table 1). Stem lesions can be watery and may develop into the stem pith with (stem rot) or without (blackleg, white mold) the formation of sclerotia. Other lesions can appear like more discrete light brown lesions but nevertheless affecting the yield of the crop (skin spot, stem canker). Some soil-borne pathogens sometimes cause aerial symptoms like necroses or chloroses (Phoma leaf spot, Verticillium wilt) occasionally associated with wilting and rolling (bacterial ring rot). Finally, root lesions, mainly caused by nematodes feeding on the roots, lead to necroses or rots. Nematodes feeding sites are good entry points for other soil microorganisms.

Among diseases affecting tubers, symptoms can be divided into three categories: galls, blemishes, and rots (Table 1). Galls consist in outgrowth and tuber deformation. The most frequent galls are provoked by powdery scab, wart, Common Scab, root-knot nematode, and false rootknot nematode. Blemishes affect only the tuber skin but they are now economically important since consumers' habits have changed and tubers are washed before selling. Blemishes can appear on the tuber surface as spots called black dot, black scurf, skin spot or powdery scab, or as areas of atypical appearance presenting a more or less pronounced scabby (common or netted scab) or silver (silver scurf) aspect. Rots, which affect the tuber flesh more deeply, include different types such as dry rots, soft rots (charcoal rot, leak, bacterial soft rot, black leg, and stem rot), flesh discoloration (pink rot) or vascular ring discoloration (ring rot, brown rot, Verticillium wilt, and Fusarium dry rots). Dry rot diseases also damage stored potatoes.

Potato is becoming a more and more important foodstuff in the world, it is therefore essential to control diseases which cause direct yield losses and decrease of farmer's incomes due to downgrading the quality of affected tubers. Therefore, knowledge about the pathogens as well as factors influencing disease severity is needed to setup efficient control strategies. Before reviewing the different causes of occurrence and development of the main soil-borne potato diseases, it is important to recall the concepts of soil inoculum potential and soil suppressiveness which describe the complex interactions between the soil, the pathogens, and the plant. While the former evaluates what the actual indigenous pathogenic inoculums could do in the rhizosphere towards the host plants if all conditions were favorable to its pathogenic activity, the second 


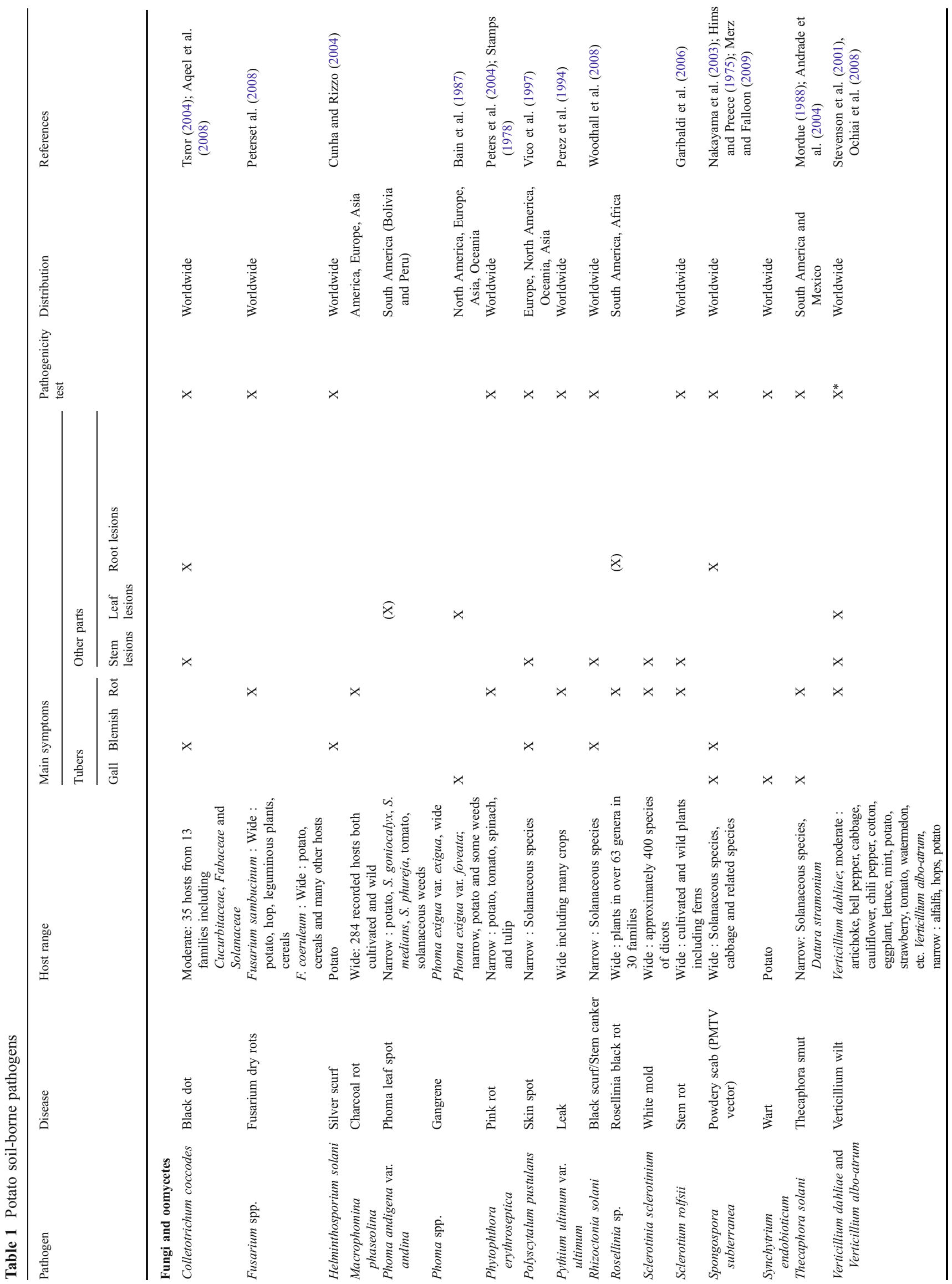




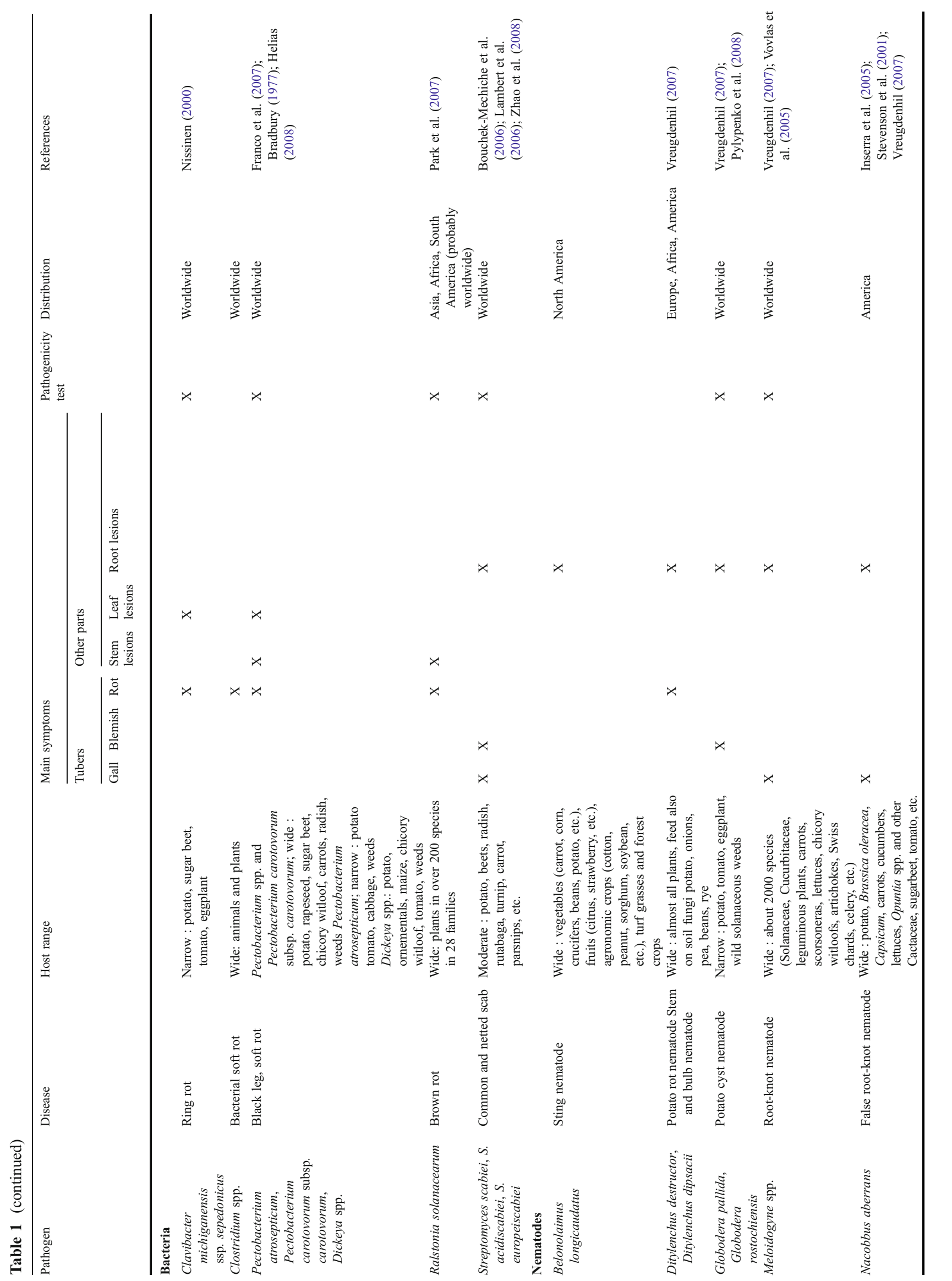




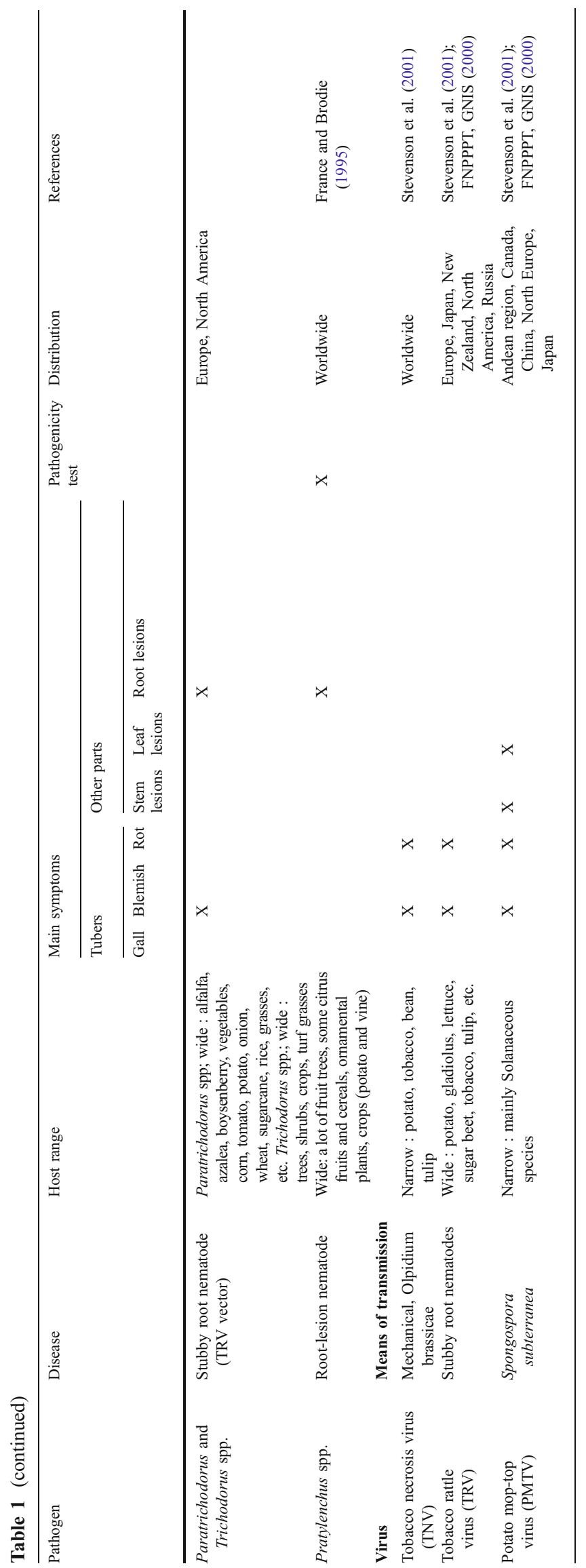

evaluates in which ways the environmental conditions may limit in situ the expression of this pathogenic activity, including the saprotrophe development, if required by the inoculum (Alabouvette et al. 2006).

Plant diseases result from the compatible interactions between a susceptible host plant and a pathogen. These direct interactions are important but should not outshadow the key role of environmental factors, which influence these interactions and thereby disease incidence or severity. In contrast to aerial diseases, the soilborne diseases are induced by pathogens which are embedded in the soil matrix. Thus, the soil interferes in many ways in the relationships between and among microorganisms, pathogens, and host plant. It can even modify the interactions among microorganisms themselves. In some soils, disease incidence or severity commonly remains low in spite of the presence of the pathogen, a susceptible host plant and favorable climatic conditions. They are called disease-suppressive soils (Messiha et al. 2007; Steinberg et al. 2007). Soil suppressiveness to diseases depends on the pathogen itself-its inoculum density and its intrinsic aggressiveness - and also on different soil factors, including both biotic and abiotic components.

In the first part of this paper, the influence of abiotic factors on disease severity will be reviewed. Then the characteristics of the inoculum and its relationships with the rest of the microbiota will be considered. Finally, risk assessment models, decision support systems, and control strategies based on collected data will be discussed.

\section{Effects of abiotic factors on the occurrence and development of soil-borne potato diseases}

Soil abiotic components such as texture, organic matter content, $\mathrm{pH}$, as well as temperature and moisture greatly affect the behavior of the pathogens and determine disease incidence or severity.

\subsection{Soil temperature}

Temperature and moisture of the soil are obviously greatly dependent on the climatic conditions, but also on some cultural practices such as irrigation. Temperature is of major importance in disease development since it determines pathogen growth rate (Baljeet et al. 2005), kind of symptoms (Bouchek-Mechiche et al. 2000), and geographical distribution of the diseases. Most of the potato pathogens can grow at soil temperatures between $10^{\circ} \mathrm{C}$ and $25^{\circ} \mathrm{C}$, the optimal potato growth temperatures (Table 2). However, gangrene, black scurf, and powdery scab are favored by mean temper- 
Fig. 1 Symptoms caused by some potato soil-borne diseases, a tobacco rattle virus (TRV, transmitted by nematodes), b root-knot nematode (Meloidogyne incognita), c common or netted scab (Streptomyces scabies), d black scurf (Rhizoctonia solani)
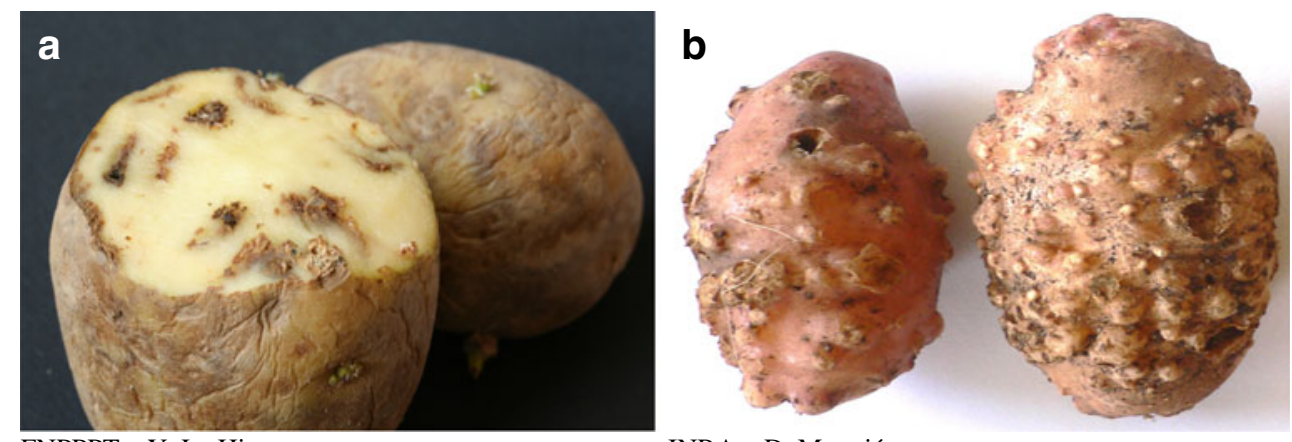

FNPPPT - Y. Le Hingrat INRA - D. Mugniéry

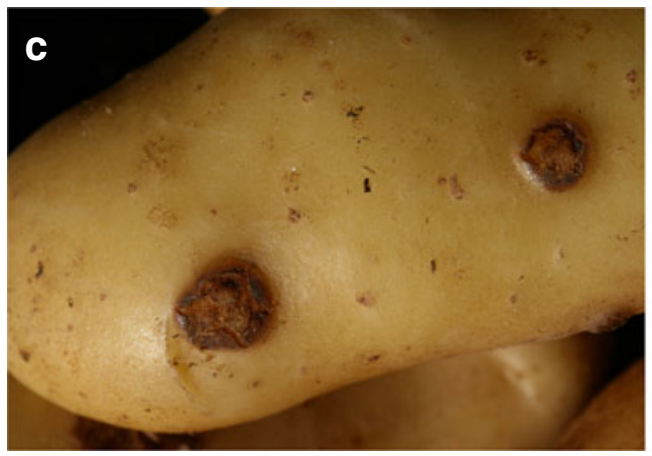

FNPPPT - Y. Le Hingrat

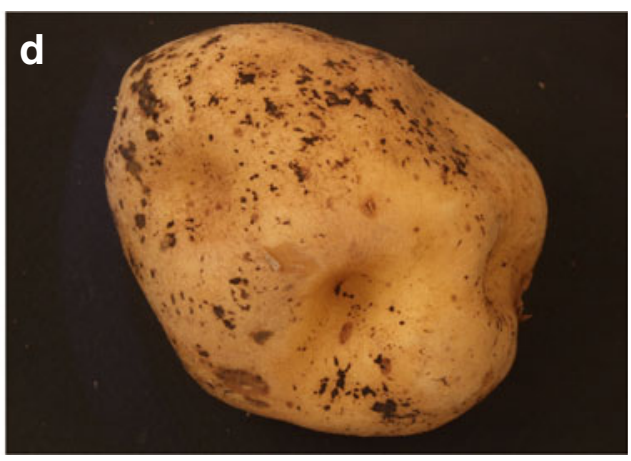

FNPPPT - Y. Le Hingrat atures below $15^{\circ} \mathrm{C}$ (Baker 1970; Gindrat 1984; Harrison 1997); on the contrary, black dot, black leg, stem rot, and charcoal rot are favored by temperatures above $27^{\circ} \mathrm{C}$. Similarly, sting and root-knot nematodes reproduce better between $25^{\circ} \mathrm{C}$ and $30-35^{\circ} \mathrm{C}$ depending on the origin of the populations.

\subsection{Soil moisture}

Soil moisture which depends on the climate and cultural practice is also determined by the soil texture (see below). In the literature dealing with interactions between soil moisture and potato diseases, many different terms are used to characterize the soil water content.

Soil moisture content, moisture-weight percentage, and water-holding capacity are used to evaluate the volume of water contained in soil. It is generally expressed as a percentage of the soil dry weight. Other publications refer to water activity which is a dimensionless quantity (between 0 and 1) describing the amount of free water in soil for biochemical reactions. Water activity, which depends on soil texture, is related to moisture content in a non-linear relationship known as a moisture sorption isotherm curve.

High soil moisture due to abundant rainfall, poor drainage, heavy soils, or irrigation, influences disease development and the opening of the lenticels which are further entry points for soil-borne pathogens into the tuber (Helias 2008). Several diseases, especially bacterial diseases, are enhanced by high moisture content (Table 2), but few diseases are favored by low levels of moisture. This is the case for black dot, some dry rots induced by Fusarium spp., stem rot, wart, common scab, and sting and root-knot nematodes. High soil moisture generally has indirect effects which might favor disease severity. This is the case of flooding that provokes oxygen depletion and $\mathrm{CO}_{2}$ enrichment resulting in an increase of Spongospora subterranea (powdery scab) development (Harrison 1997). In some cases, the influence of soil moisture on disease severity is not clearly demonstrated. Depending on the studies, black scurf, stem canker, silver scurf (Helminthosporium solani), and Thecaphora smut (Thecaphora solani) are either positively or negatively correlated with soil moisture (Adams et al. 1987; Hide and Firmager 1989; Sepulveda et al. 2000; El Bakali and Martin 2006; Wale et al. 2008). Conversely, high relative humidity during storage of tubers has always a negative impact (Table 2).

\subsection{Soil texture}

The soil texture describes the relative percentage of sand, loam, and clay contents. Most of fungal diseases are enhanced in light sandy soils (Table 3). Conversely, it is generally accepted that clay soils favor bacterial activity (Marshall 1975; Alabouvette et al. 1996) explaining that clay or heavy soils are conducive to bacterial soil-borne diseases (ring rot, soft rot, brown rot, and netted scab). Concerning nematodes, no general rule can be drawn up as some species are more prevalent in heavy soils (root-knot 


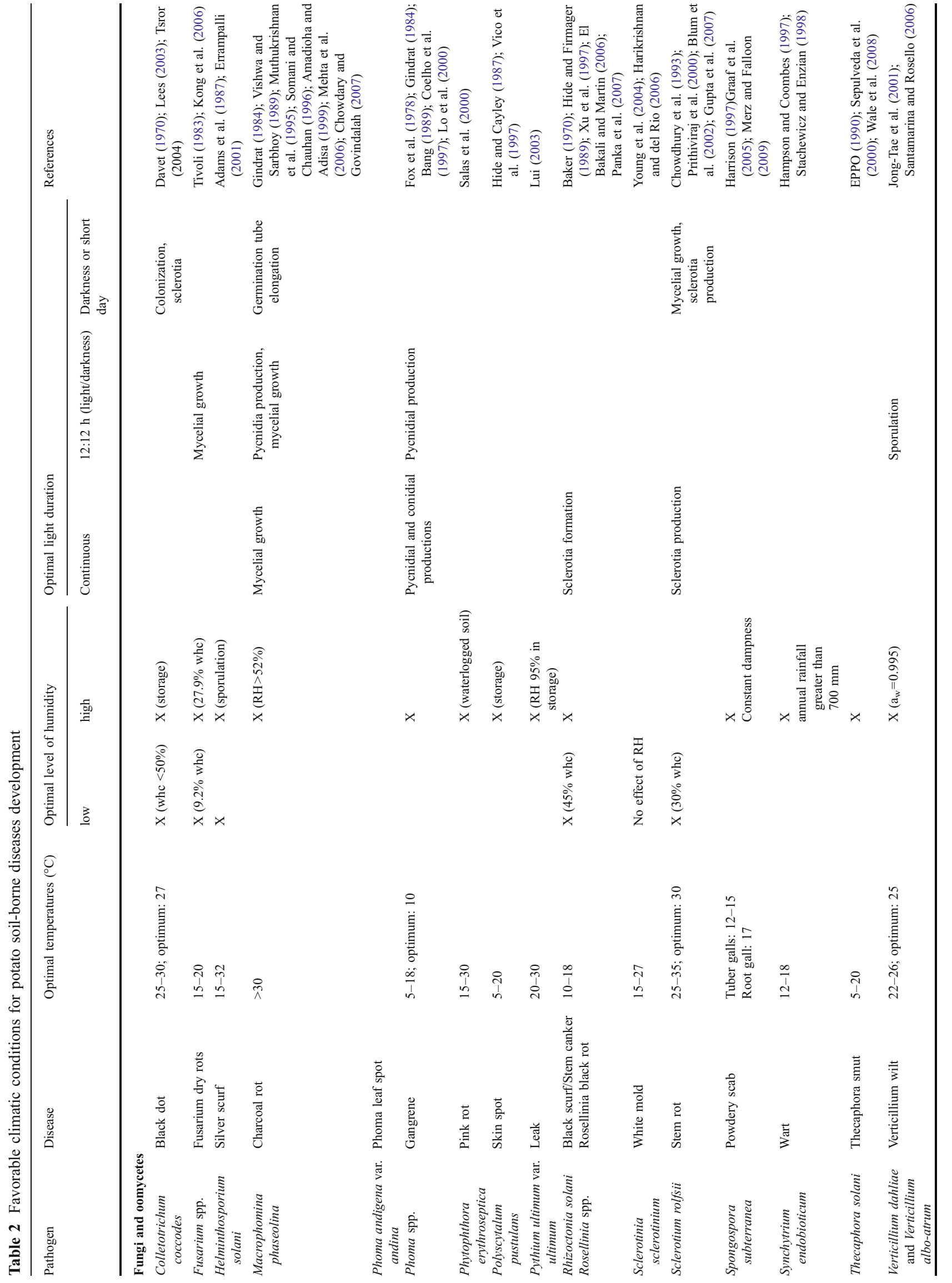




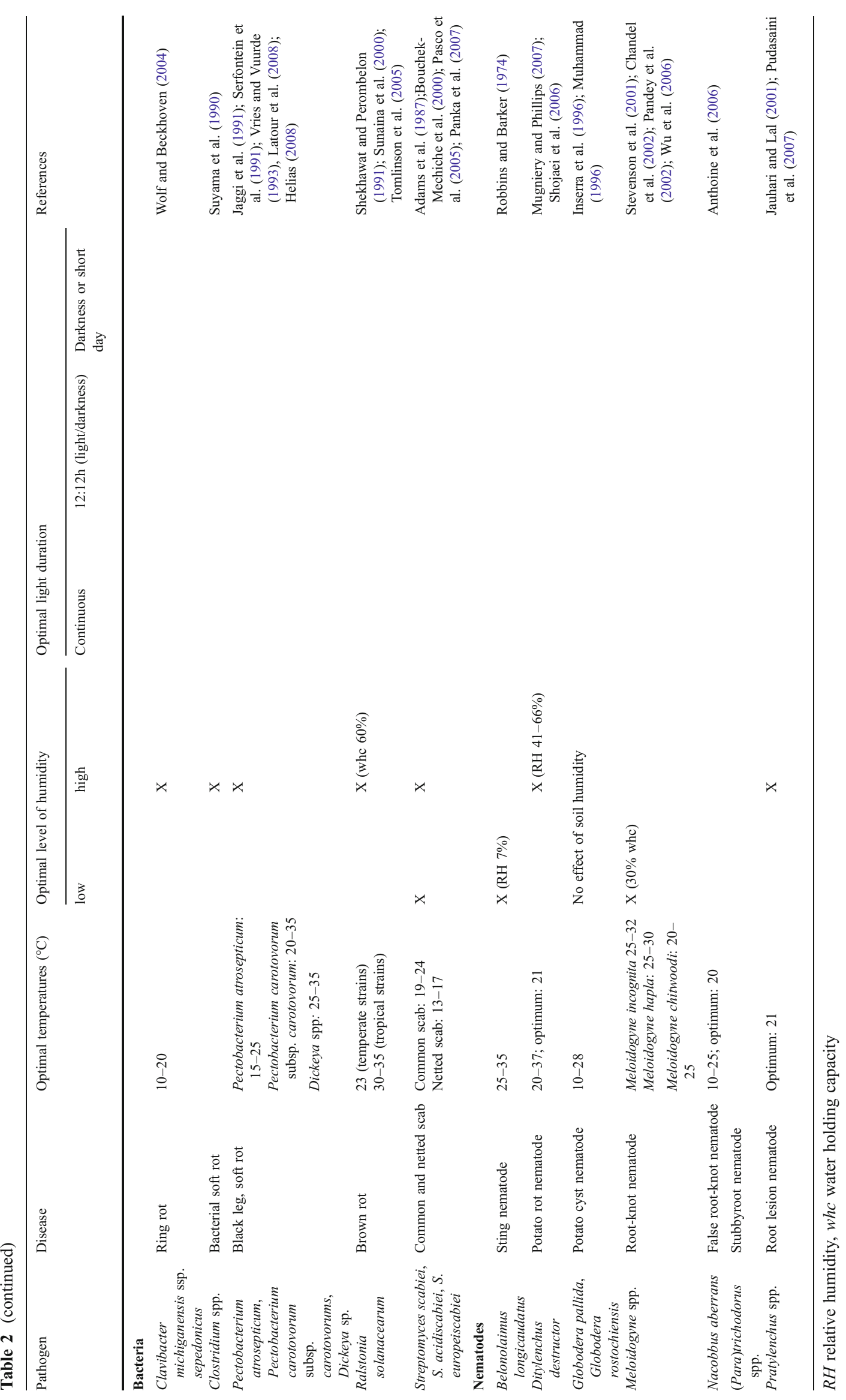




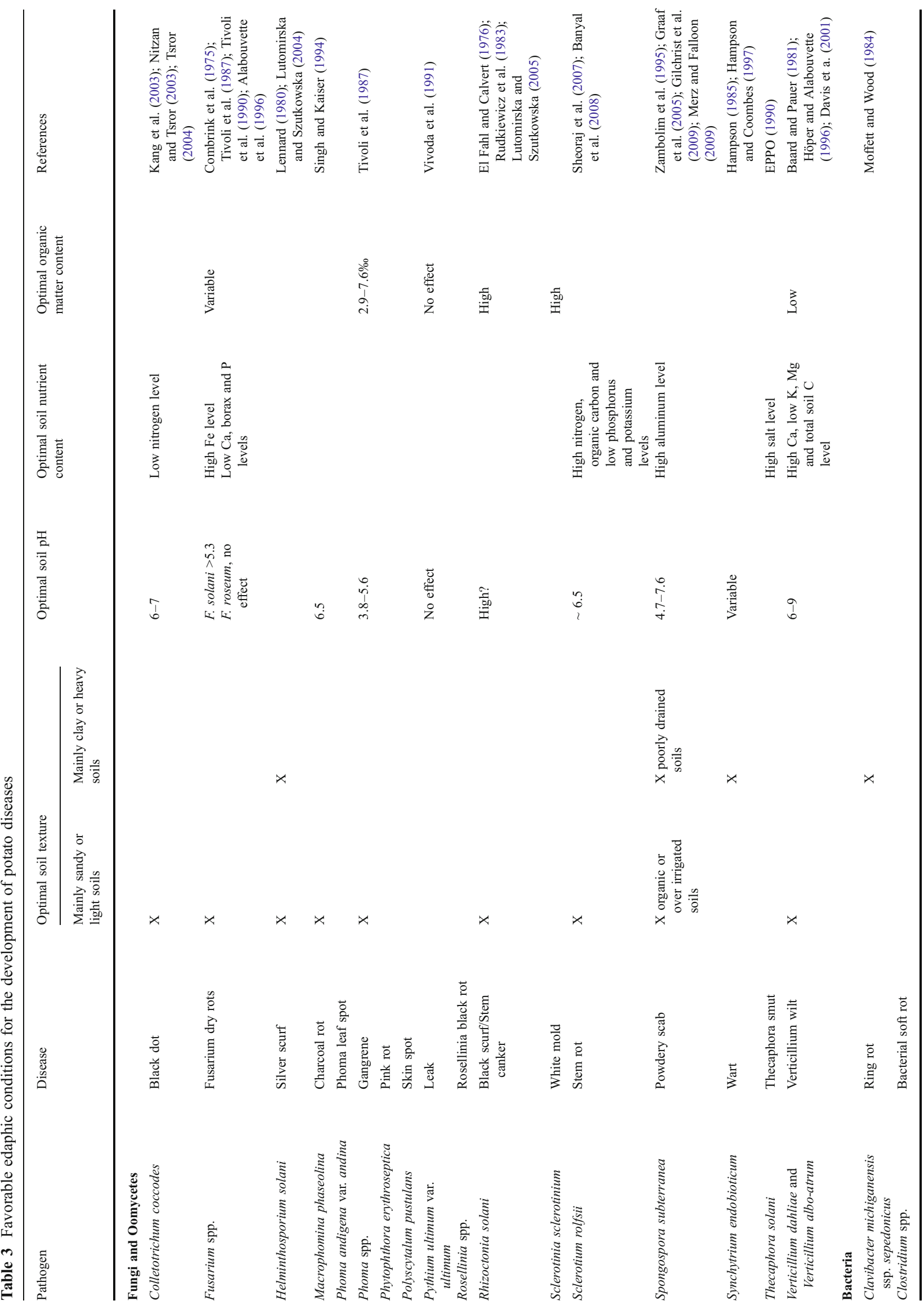




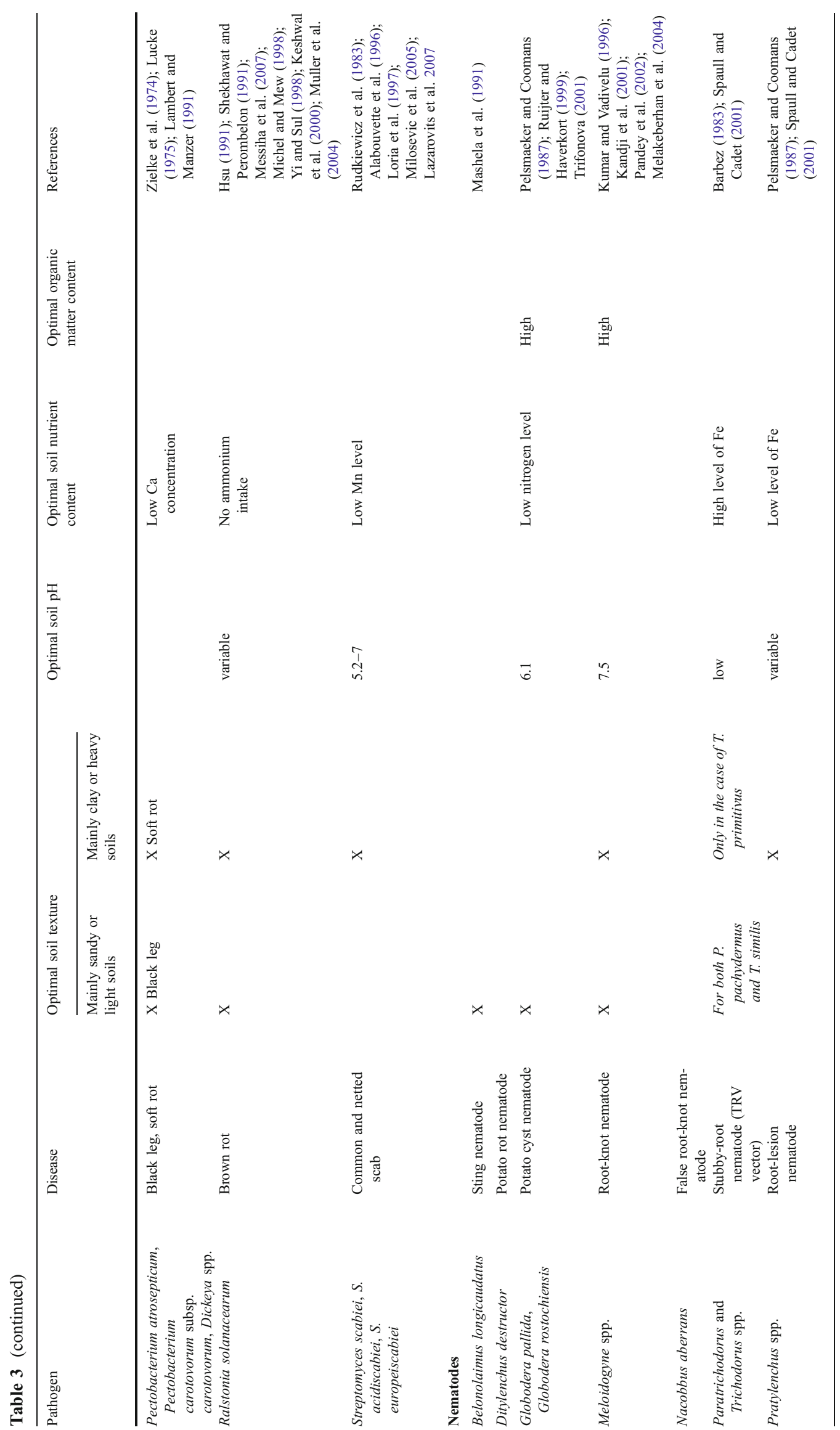


nematodes) and other species in light soils (sting nematodes). Soil texture also influences soil structure, through the distribution of different pore sizes, determining the actual living space for bacteria, fungi, and predators. It also influences the water activity; water retained in pores of narrow diameter being less available for organisms that water present in large pores.

\subsection{Soil $\mathrm{pH}$}

Disease development is also influenced by soil $\mathrm{pH}$ linked to soil nutrient availability (Table 3 ). Soils with extreme $\mathrm{pH}$ values are often highly suppressive to several plant diseases (Höper and Alabouvette 1996). However, pH fluctuations resulting from amendments influence pathogens and disease development. Decreasing $\mathrm{pH}$ increases the availability of phosphorus, nitrogen, and aluminum ions and decreases potato cyst nematode, brown rot, and common scab damages, respectively (Mulder et al. 1997; Michel and Mew 1998; Ruijter and Haverkort 1999; Mizuno et al. 2003). On the contrary, addition of urea in soil induces a very large increase in $\mathrm{pH}$ and a good control of Synchitrium endobioticum, the fungal pathogen causing wart (Hampson 1985).

\subsection{Soil organic matter}

Soil organic matter is both the substrate for and the result of microbial activity. In addition, together with clay, organic matter affects soil structure and thus moisture content and aeration. The quantity of organic matter in a soil has an effect on the appearance and the development of diseases but its quality is also an important point which has been too poorly addressed (Alabouvette et al. 1996).

Most physico-chemical factors are not independent from one to the others, which makes experiments and data interpretation very difficult. Soil texture can affect humidity, soil amendments impact on $\mathrm{pH}$, and all those factors influence availability of chemical elements. Thus, the pathogenic inoculum present either in the soil or on the tuber surface has to find the optimal climatic and edaphic conditions to develop.

\section{Effects of biotic factors on the occurrence and development of soil-borne potato diseases}

\subsection{Autecology of pathogens}

\subsubsection{Inoculum sources, survival and dissemination pathways}

The survival of soil-borne pathogens during periods without potato crop depends on their ability to resist to unfavorable conditions. Most of them survive in soil under the form of resistant structures able to directly infect the new host crop. Some pathogens can also survive as saprophytes on host crop residues or on alternative hosts during winter. Finally, inoculum can also be introduced into the field by the seeds; it is called seed- or tuber-borne inoculum. Inoculum sources are diverse and for many diseases several inoculum sources can play a role (Table 4). Soil-borne fungi produce different conservation structures. Fusarium spp. forms chlamydospores resistant to adverse conditions, Rhizoctonia solani, Verticillium spp., Sclerotinia sclerotinium overwinter as sclerotia. Bacteria can survive over winter with favorable moisture, temperature, and soil type (Ficke et al. 1973; Bradbury 1977; Loria et al. 2008). Nematodes can survive and persist in soil as protective cysts surrounding the eggs (Globodera spp.) or as juveniles in host roots (Meloidogyne spp.; Qian et al. 1996; Wharton and Worland 2001).

In the absence of resistant structures and of efficient saprophytic abilities, some pathogens need alternative hosts to survive in absence of potatoes. These alternative hosts frequently belong to the Solanaceous family and act as a long-term reservoir of the pathogen (Chang et al. 1992; Tomlinson et al. 2005).

Fungal dissemination occurs frequently as spores (conidiospores, chlamydospores, pycnidiospores, sporangiospores, oospores, and zoospores) or mycelium transported by water (rain, irrigation, and flow in soil), by soil adhering to farm equipment or introduced by contaminated seed tubers (Zambolim et al. 1995; Stevenson et al. 2001; Bae et al. 2007). Moreover, some pathogens liberate mobile dissemination forms such as zoosporanges. Zoospores of Phytophthora erythroseptica, S. subterranean, and $S$. endobioticum are responsible for short-distance dissemination of these pathogens (Wharton et al. 2007; Merz and Falloon 2009). Adult nematodes such as Pratylenchus penetrans are able to migrate on quite long distances better than do larvae (Pudasaini et al. 2007).

\subsubsection{Relationship between inoculum density and disease severity}

Although there is not always a clear and linear relationship, the severity of the disease generally increases with an increasing level of inoculum (Table 4). Sometimes, a minimum inoculum threshold is needed to initiate the disease development. This is the case, for instance, for potato cyst nematodes (Samaliev et al. 1998). Conversely, the disease severity of black dot does not increase any more beyond a maximum threshold of inoculum density (Nitzan et al. 2008). In fact as stated above, the relationship between inoculum density and disease severity greatly depends on the environmental factors which determine the level of soil suppressiveness. 


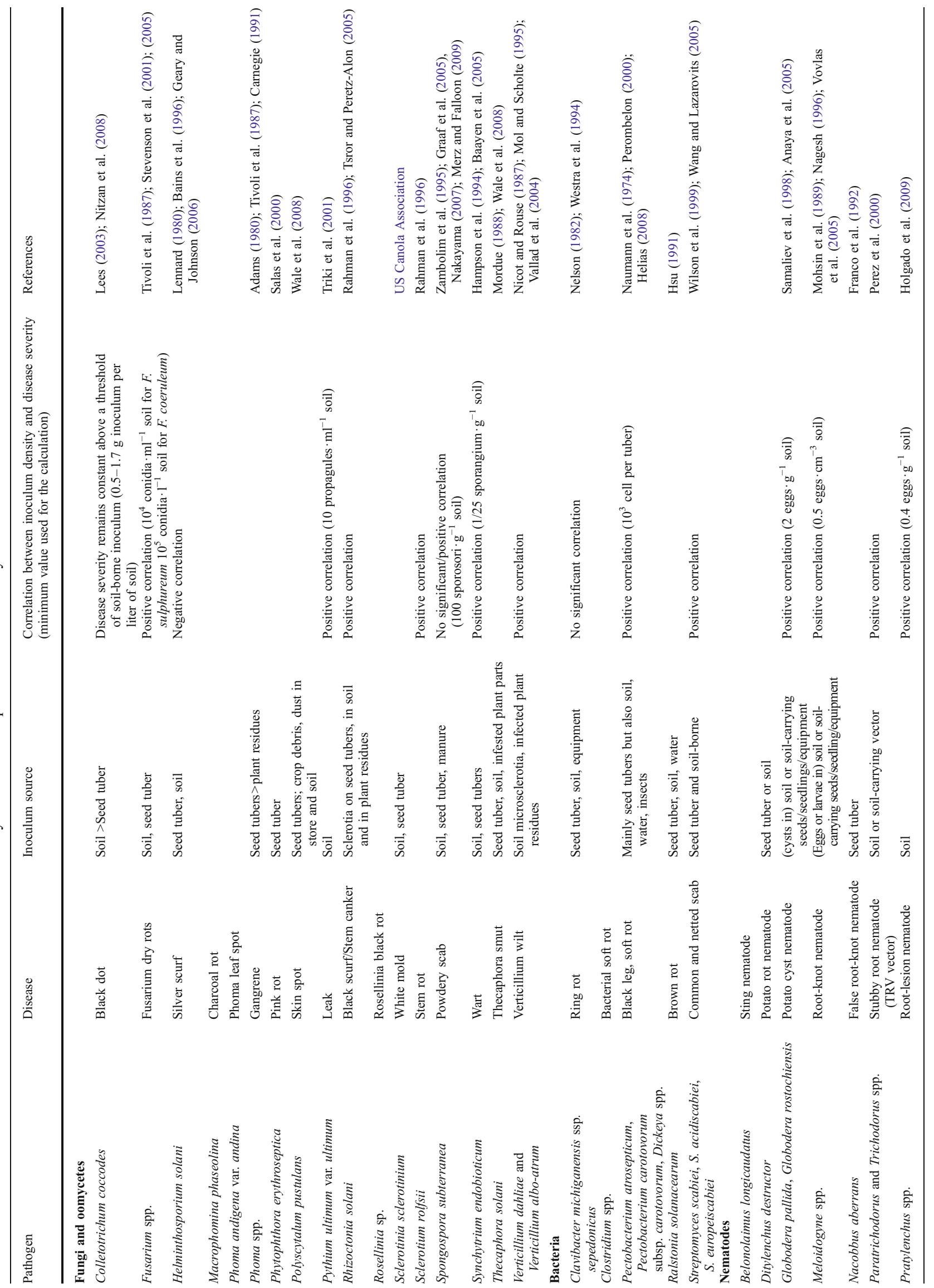




\subsubsection{Mechanisms of infection}

Potato plants are essentially composed of cellulose, a very solid polymer and tubers are enveloped in a protective covering called periderm made of a suberin biopolymer providing the primary barrier against diseases, insects, dehydratation, and physical intrusions (Lulai 2001). Soilborne pathogens of potato have various ways to penetrate the host plant and break physical barriers. They enter the roots, young sprouts, underground stems, stolons, or tubers. Some pathogens cannot infect intact tuber periderm or lenticels and penetrate through wounds (Stevenson et al. 2001; Taylor et al. 2004) whereas other pathogens can penetrate either directly by mechanical and/or enzymatic degradation of the host's cells or through natural openings (stomata, lenticels, eyes) (Table 5).

Once they have penetrated the host, pathogens colonize plant tissues. Fungi grow through the parenchyma of the cortex and often reach the vascular vessels. T. solani, $S$. endobioticum, and Streptomyces spp. penetration provokes hypertrophy of the colonized tissues resulting in galls. They grow in the plant, induce cell death, and feed on them saprophytically. They secrete phytotoxins - for example thaxtomin produced by Streptomyces spp.-inducing the formation of several layers of suberized corky cells, creating a large lesion firmly integrated within the tuber skin (Stevenson et al. 2001; Mulder et al. 2008; Perez and Torres 2008). Compared to common scab development, powdery scab pustules formation is a relatively short process, at the end of which a single wound cork layer remains that covers the entire lesion. After hardening off, this layer can be easily removed from the lesion without any damage of the underlying tissues (Delleman et al. 2005). Colletotrichum coccodes, H. solani, Polyscytalum pustulans, $R$. solani, S. subterranea, and Streptomyces spp. are responsible for several superficial alterations called blemishes. Colonization by those pathogens is usually limited to superficial layers of tuber periderm (Harrison 1997; Stevenson et al. 2001; Cunha and Rizzo 2004; Lehtonen et al. 2008; Loria et al. 2008) but they can colonize other parts of the plant until they reach vascular system. Streptomyces spp. responsible for netted scab blemishes has pathogenic mechanisms that are assumed to not implicate thaxtomin but rather a necrotic protein (Bouchek-Mechiche et al. 2006).

Fungi and bacteria-causing rots produce a wide range of hydrolytic enzymes such as cellulases, pectinases, xylanases, and proteases (Olivieri et al. 2004). They are responsible for tissue maceration and cell death, after which the microorganisms have access to the nutritional resources of the dead plant tissues (Amadioha 1997; Aveskamp et al. 2008). Pectobacterium spp. develop an original pathogenic strategy based on quorum sensing, which utilizes freely diffusible chemical signal molecules allowing pathogenic bacteria to synchronize the production of virulence factors and make the pathogenic attack more efficient (Liu et al. 2008). Finally, nematodes attacking potatoes can be classified into two categories: ectoparasites and endoparasites. Ectoparasites nematodes (Belonolaimus longicaudatus, Paratrichodorus spp., and Trichodorus spp.) are mobile and feed on potato roots in the area of cell division and elongation without penetrating the root (Stevenson et al. 2001; Mugniéry 2007). The endoparasitic nematodes of potato, $D$. destructor and $P$. penetrans are migrating endoparasites; they feed from cell to cell within the host, whereas Globodera spp., Meloidogyne spp., and N. aberrans are sedentary endoparasites, they induce specialized feeding sites in plant roots. $D$. destructor and $P$. penetrans penetrate underground parts of the plant, feed on the cortical cells, and migrate into the roots, destroying cell after cell. Globodera pallida, Globodera rostochiensis, Meloidogyne spp., and N. aberrans develop feeding cavities in host root, causing galls (Mugniéry 2007).

\subsubsection{Genetic variability}

A soil-borne disease can be caused by several species of pathogens belonging to a single genus, by one species, or even by a subgroup of a species. Each species or subspecies is adapted to particular conditions or variety. Knowledge of the genetic diversity of pathogens is useful for precise diagnosis and control of potato diseases.

Since Erwinia has been renamed and divided into two different genera, Pectobacterium and Dickeya (Helias 2008), bacterial soft rot previously attributed to Erwinia carotovora, Erwinia atroseptica, and Erwinia chrysanthemi is in fact one disease caused by several species belonging to different genera (Table 5). Pectobacterium spp. and Dickeya spp. are frequently associated with bacteria of the genus Clostridium which includes very numerous Gram-positive anaerobic bacteria. Clostridium puniceum is one of the few well-characterized pectolytic clostridia isolated from rotting potato tubers (Stevenson et al. 2001; Prescott et al. 2003).

Within a same species, the pathogen may belong to different groups with various genetic, pathogenic, and physiological traits leading to the characterization of races, biovars and, recently, genomovars - strains which are phylogenetically differentiable, but are phenotypically indistinguishable - phylotypes and sequevars - one or several strains with a given sequence (Nouri et al. 2009). Fungi without sexual reproductive stage related to the potato disease cycle, such as Colletotrichum spp., Fusarium spp., or Verticillium spp., are classified in vegetative compatibility groups (VCGs). Within a VCG, hyphae belonging to different isolates can anastomose and form stable heterokaryons, whereas hyphae from isolates belonging to 


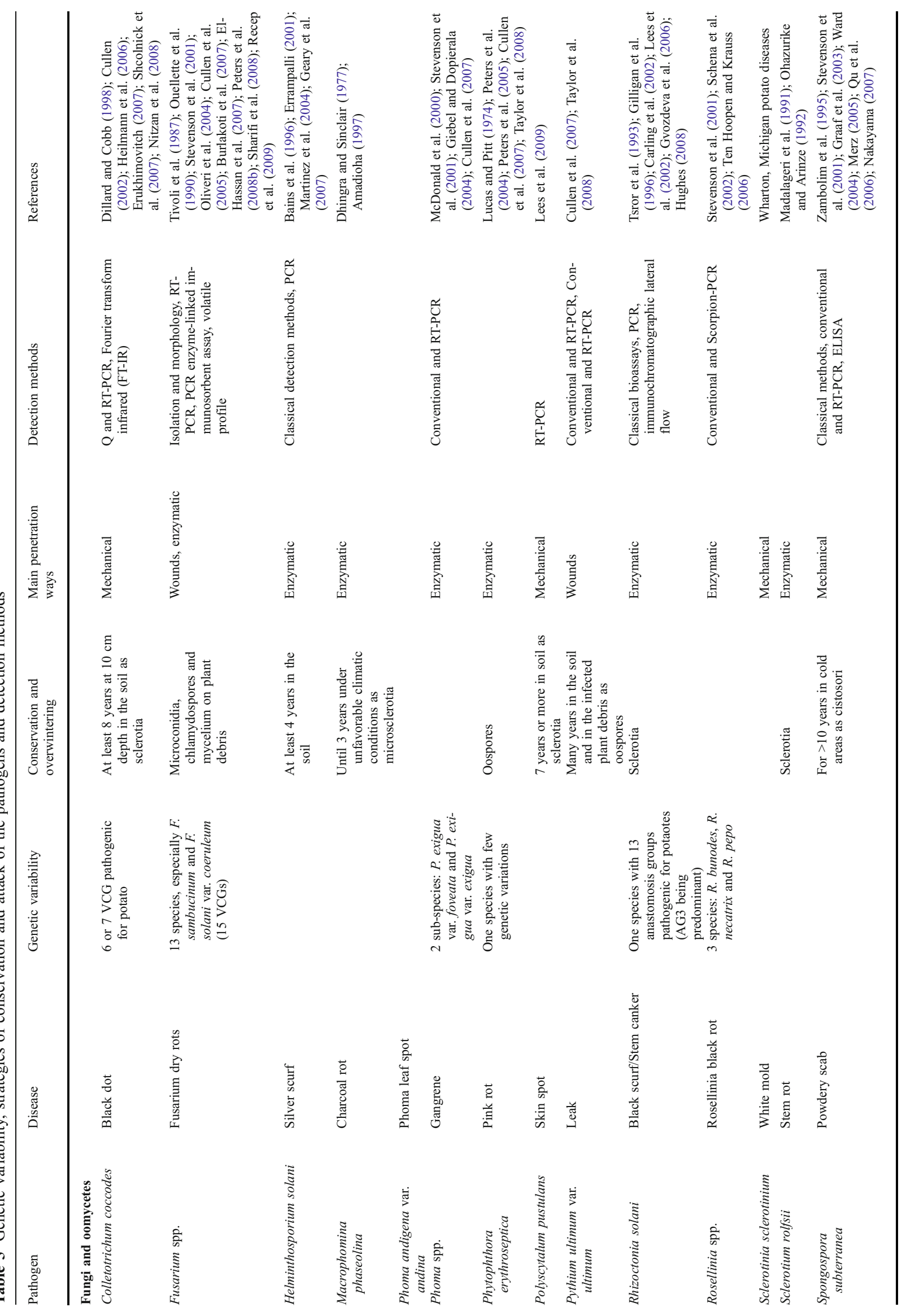




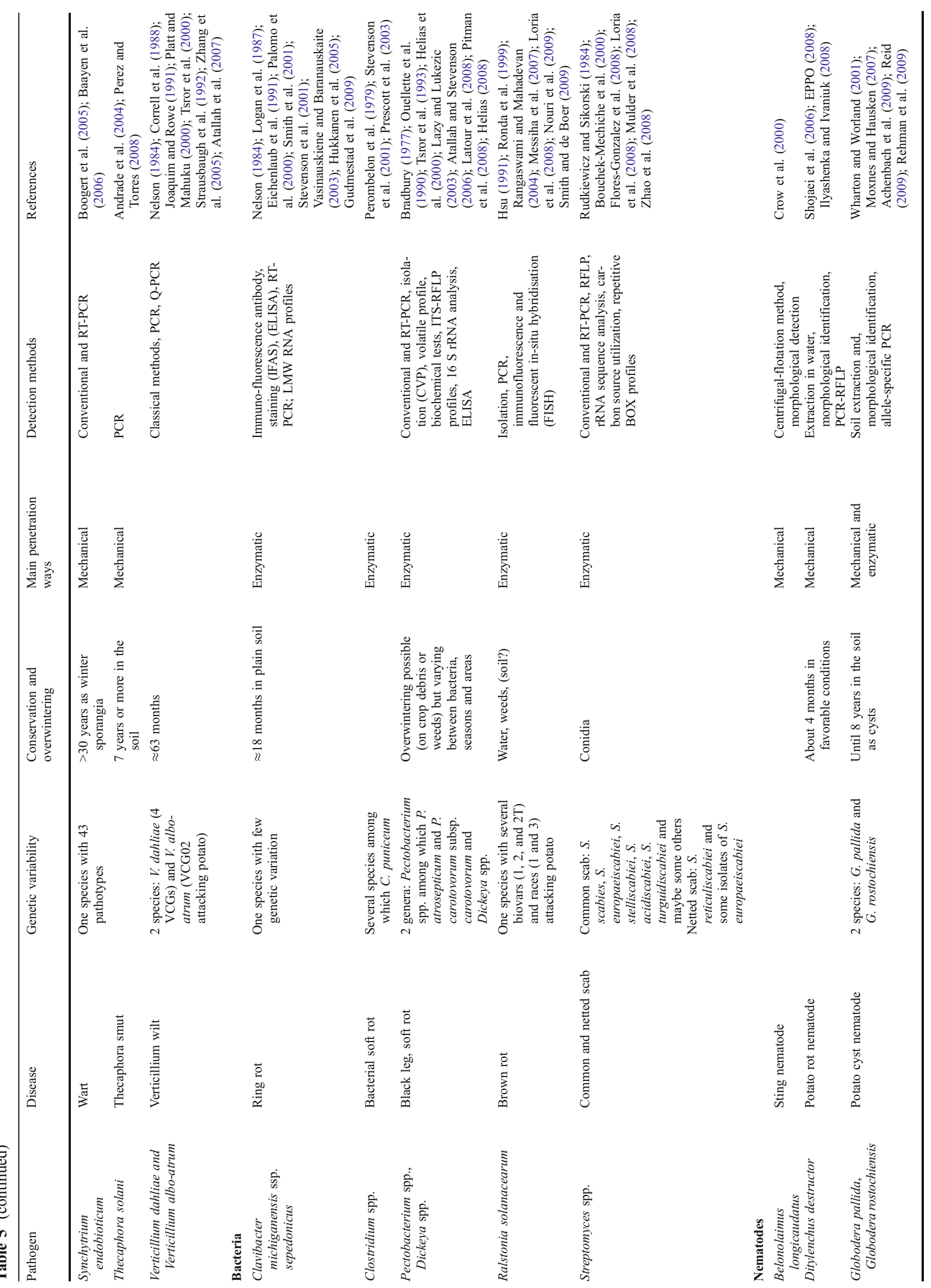




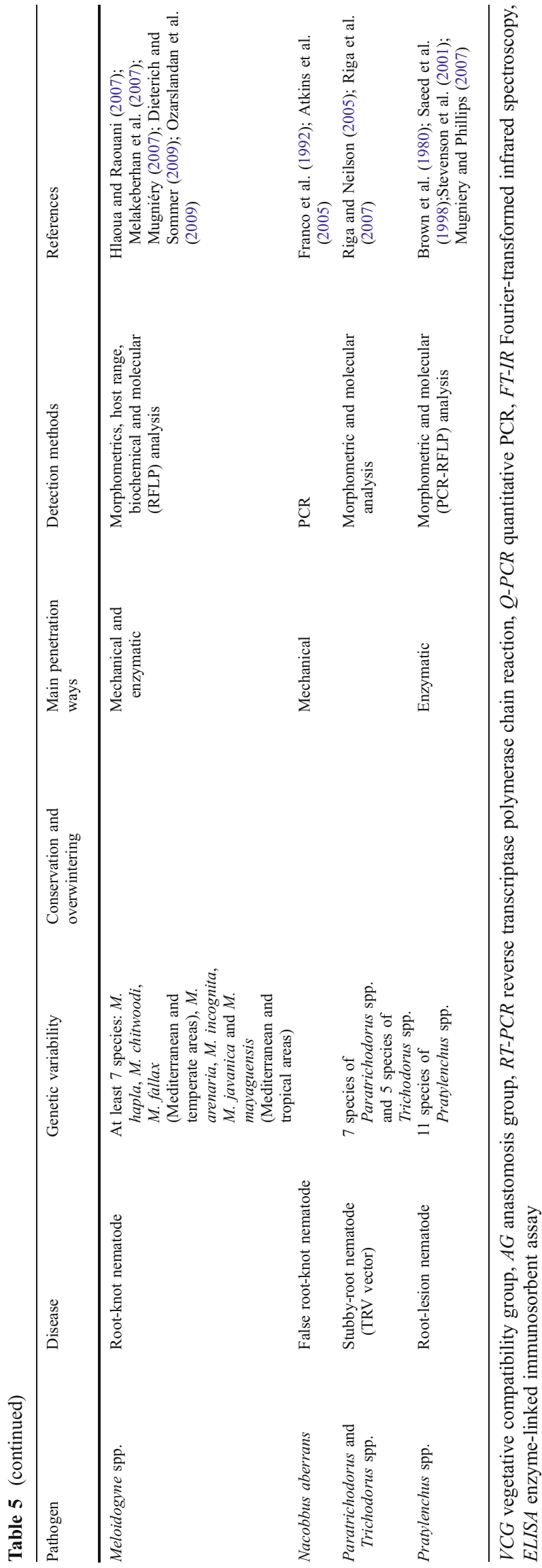

different VCGs cannot. This mechanism is the only known mechanism of genetic exchange between individuals of asexual fungi (Hiemstra and Rataj-Guranowska 2003). Hyphal anastomosis is also used to categorize the isolates of $R$. solani into anastomosis groups (AG). Presently, 13 AGs have been described, several of which being divided into subgroups. Individual AGs are not strictly associated with a specific host but rather with a family of hosts which can be in turn narrow or very broad, for example $A G 1$ with rice mainly and AG 8 with various cereals. AG 3 isolates, and more specifically isolates from the AG 3 PT subgroup, are often associated with potato diseases (Fiers et al. in press; Kuninaga et al. 2000; Carling et al. 2002). However it was shown, in Great Britain and France, that AG 2-1 and AG 5 can cause disease in potato crops but with a much lower incidence than AG 3 PT (Campion et al. 2003; Woodhall et al. 2007).

As a result of the genetic evolution of pathogens, new pathotypes are regularly discovered. Conversely, some populations such as $P$. erythroseptica and Clavibacter michiganensis subsp. sepedonicus vary slightly in pathogenicity and in genetic diversity suggesting a relatively recent introduction of a small founding population of the pathogen (Smith et al. 2001; Peters et al. 2005). Genetic evolution can be achieved by vertical or horizontal gene transfer. Meloidogyne populations originally did not possess the cell wall-degrading enzymes required to invade host roots. Although the mechanism of horizontal gene transfer remains largely elusive, it has been speculated that a gene coding for a cell wall-degrading enzyme was horizontally transferred from a rhizobial bacterium to the nematode and was kept in the genome of the nematode by strong selection pressures representing important initial steps facilitating the invasion of plants by nematodes (Dieterich and Sommer 2009). By genetic evolution, pathogens can adapt to the different environmental conditions they are submitted to. This enables them to skirt control measures and continuously forced farmers to use new control methods.

\subsubsection{Diagnosis and detection methods}

Rapid detection of plant parasitic pathogens enables to set up adapted control measures and avoid disease expansion and yield losses, even if the infestation level is low. Classical detection methods begin with visual observation and characterization of symptoms followed by identification using morphologic traits for nematodes (Crow et al. 2000; Riga and Neilson 2005; Melakeberhan et al. 2007; Mugniéry 2007) or isolation on selective media for fungi and bacteria. Carbon source utilization, sugar degradation, and production of specific enzymes allow the biochemical identification of bacteria (Flores-Gonzalez et al. 2008; Pitman et al. 2008). However, these classical methods are often not accurate enough to distinguish between different 
strains or pathovars of the same species. Molecular biology based-diagnosis and detection methods are expected to complement classical diagnosis. The most developed detection methods are based on polymerase chain reaction (PCR), which amplifies DNA regions specific of the pathogen of interest (Table 5). The quantitative reverse transcriptase PCR is currently among the most powerful methods for the diagnosis of pathogens in complex environments. Indeed, it enables to quantify the ARN of the pathogen present in a sample. Fingerprinting methodsrestriction fragment length polymorphism or amplified fragment length polymorphism - are used for intraspecific identification of pathovars or races of bacteria, fungi, or nematodes (Abeln et al. 2002; Cullen et al. 2007; FloresGonzalez et al. 2008; Pitman et al. 2008). Fluorescent in situ hybridisation or stable low molecular weight DNA profiles were developed to detect $R$. solanacearum and $C$. michiganensis var. sepedonicum, respectively (Ronda et al. 1999; Palomo et al. 2000). Immunological techniques such as immunochromatographical lateral flow, enzyme-linked immunosorbent assay and immunofluorescence are based on the recognition of specific markers at the surface of pathogenic cells to detect and identify the pathogens (Ronda et al. 1999; Merz 2005; Hughes 2008). Fungal pathogens display typical infrared spectra that differ from the spectra of substrate material such as potato; they can be early and rapidly detected by Fourier transform infrared microscopically based technique (Erukhimovitch 2007). Finally, monitoring of normal and disease-induced volatile profiles in stored potatoes or of the light reflected from plant in fields are valuable techniques to detect stress and thus potential pathogenic infections (Ouellette et al. 1990; Heath et al. 2000).

\subsection{Interactions between microorganisms, organisms,} and pathogens

Potato pathogens are not the only microorganisms living in the potato surroundings. A huge microbial biomass is associated and interacts with potatoes. About $10^{7}$ bacteria colony forming units per gram of soil live in the potato rhizosphere and potato geocaulosphere which is the volume of soil surrounding the tubers (Lazarovits et al. 2007). The structure of microbial and nematode communities in the geocaulosphere varies according to the plant age and other factors related to cultivar, nutritional status, biotic and abiotic stresses, etc. (Al-Hazmi et al. 1993; Krechel et al. 2002; Ferreira et al. 2008; Desgarennes et al. 2009; Manici and Caputo 2009).

Earthworms and nematodes favor pathogen mobility by transporting them through the soil (Jensen 1978; Table 6). Nematodes enhance potato diseases because they act as vectors of the pathogens. They also enhance the diseases either by facilitating the development of other pathogensacting as mechanical wound agents and providers of necrotic tissues for pathogen penetration or nutritionor by benefiting of their attacks as opportunistic microorganisms (Jensen 1978).

The microbial or faunal interactions in the geocaulosphere are involved in disease suppressiveness of the soil. Two classical types of suppressiveness of soil are known. General suppression is related to the global activity of the whole microbial biomass in the soil. In contrast, specific suppression is due to the specific activity of certain individuals or groups of microorganisms (Alabouvette et al. 1996; Weller et al. 2002). For instance, Serratia plymuthica, Pseudomonas spp., Bacillus spp., Streptomyces spp., and Trichoderma spp. (Kumar and Khare 1990; Kamensky et al. 2002; Krechel et al. 2002) are able to decrease the severity of several potato diseases (Table 6). They can be considered as biological control agents. Some biological control agents can act directly against fungal pathogens by enzymatic degradation of their cell walls (Kamensky et al. 2002; Li et al. 2002), by parasitism - as it seems to be the case against numerous nematodes(Nunez-Camargo et al. 2003; Papert et al. 2004), by antibiotics production (Grosch et al. 2005), by siderophore secretion that reduces the availability of iron needed by plant pathogens (Bharadwaj et al. 2008) or by interfering with communication between pathogens, i.e., by degrading molecules involved in the "quorum sensing" mechanisms of Pectobacterium spp. (Dong et al. 2004). Indirectly, biological control agents can lead to the plant strengthening and a better resistance to pathogen attacks by producing plant growth hormone or by inducing the production of plant defense molecules such as phytoalexins and PR proteins (Stevenson et al. 2001; Larkin 2008). Mycorrhizal fungi also have a beneficial effect; inoculation with arbuscular mycorhizal fungus suppressed tuber dry rot and reduced stem canker and black scurf (Bharadwaj et al. 2008).

\subsection{Interactions between plants and pathogens}

The major method to control potato diseases is to find resistant cultivars to a majority of pathogens especially since the use of chemicals is limited (INRA and Cemagref 2005; Paillotin 2008). Different levels of resistance towards most of the soil-borne potato diseases have been observed among potato cultivars. Wild species of Solanum provide excellent sources of disease resistance genes that may be introgress into $S$. tuberosum genome by interspecific crossing (Jansky and Rouse 2003; Table 7) and international structures such as the International Potato Center in Peru are aiming at preserving the genetic diversity of native potatoes. Varieties of potato which contain color pigments are more and more utilized in current breeding programs 


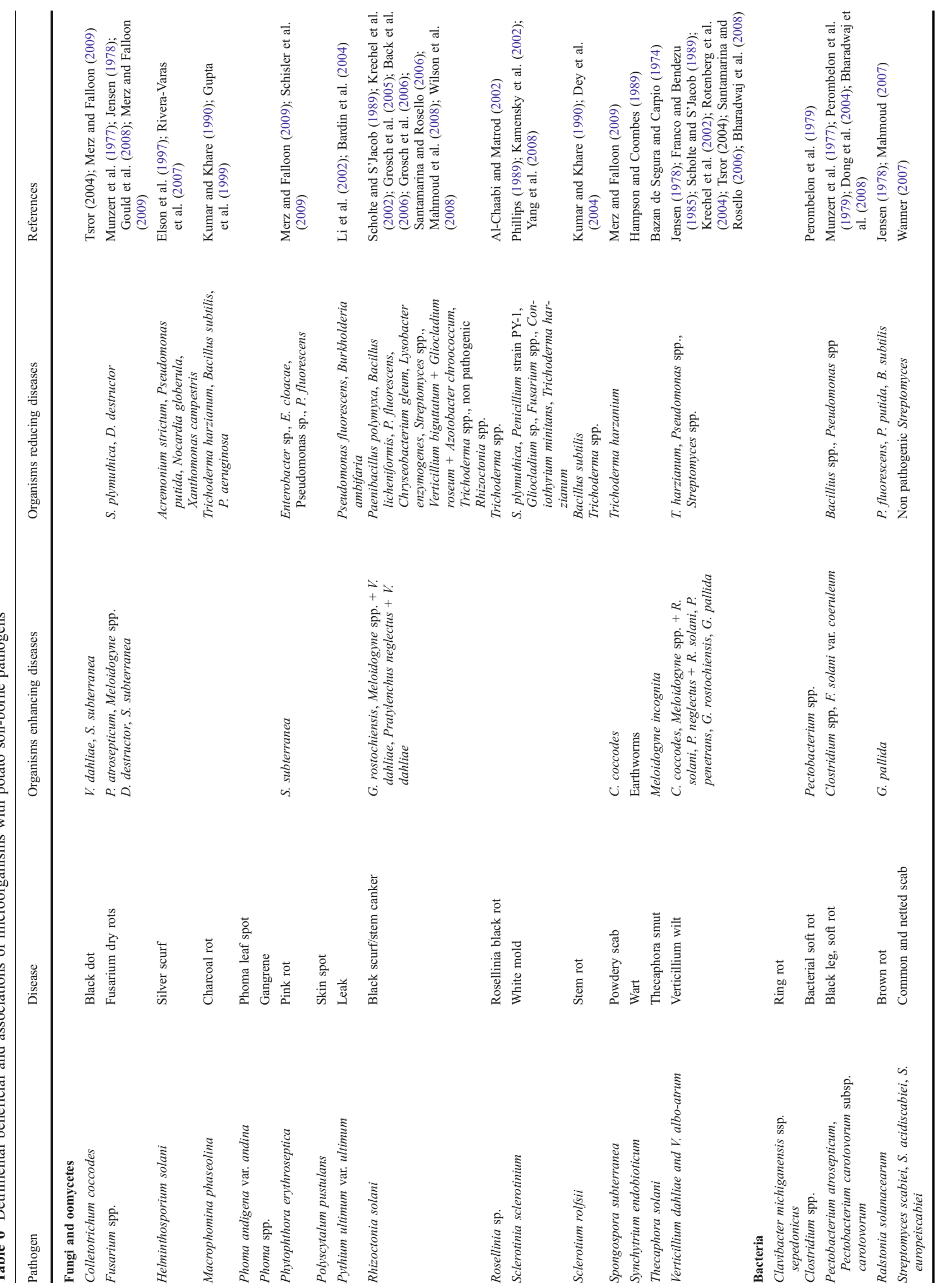


because cultivars producing anthocyanins can provide better resistance to soft rot or other diseases compared to white/yellow flesh cultivars (Wegener and Jansen 2007). Cultivars resistant to several diseases were obtained, but simultaneous resistance to all pathogens is very difficult to achieve. Moreover, for some diseases, new genotypes of pathogen appear regularly and overcome plant defense turning the former resistant cultivars into susceptible ones. Hence the levels and durability of field resistance are often highly depending on numerous abiotic and biotic factors still neither well-known or controlled.

Resistant potato cultivars counteract pathogenic attacks by plant defense reactions that generally lead to the production of suberin and antimicrobial agents, activation of defense genes and trigger hypersensitive cell death (Levine et al. 1994) delaying the pathogen development in plant tissues until a wound periderm could form. Susceptible cultivars produce non-uniform deposits of suberin making them less performing against pathogens (Finetti Sialer 1990; Ray and Hammerschmidt 1998). The anti-microbial agents produced by potatoes can be glycoalkaloids ( $\alpha$-chaconin and $\alpha$-solanine), phenolic compounds and phytoalexins, antimicrobial compounds produced by the plant after pathogen attacks (Okopnyi et al. 1983; Lyon 1989; Ray and Hammerschmidt 1998; Zagoskina et al. 2006; Baker et al. 2008; Lerat et al. 2009). Plants also produce inhibitors of virulence factors (Kim et al. 2006). Another plant defense reaction called systemic acquired resistance (SAR) spreads a signal through the surrounding cells. It allows plants to become highly resistant to subsequent infection by the original pathogen but also by a wide variety of other pathogens. For example, foliar SAR-inducing applications of (benzo $(1,2,3)$ thiadiazole-7-carbothioic acid S-methyl ester-BTH and harpin) reduce the numbers of root lesion nematodes (Pratylenchus spp.) and root knot nematodes (Meloidogyne chitwoodi; Collins et al. 2006).

\section{Effects of cultural practices on the occurrence and development of soil-borne potato diseases}

Each technical choice made by farmers concerning the way of growing potatoes plays a predominant role on the quantitative and qualitative yield. All cultural practices may impact disease development.

\subsection{Rotations}

The most traditional way to control diseases is to use crop rotations including a nonhost plant that can "sanitize" the soil (Alabouvette et al. 1996). Several studies show good results when potatoes are grown only once every 3 or 4 years and, as the other practices, it should be thought in a systemic approach (Table 8). The 
Table 7 Some wild potato cultivars harboring resistance towards pathogens

\begin{tabular}{lll}
\hline Cultivar & Resistance & References \\
\hline Solanum vernei & Spongospora subterranea & Merz and Falloon (2009) \\
Solanum acaule & Clavibacter michiganensis var. sepedonicus & Laurila et al. (2003) \\
Solanum commersonii & Ralstonia solanacearum & Kim-Lee et al. (2005) \\
Solanum bulbocastanum & Meloidogyne chitwoodi & Nitzan et al. (2009) \\
Snowder (Solanum tuberosum x Solanum & Pythium ultimum and Phytophthora & Salas et al. (2003); Thompson et al. \\
berthaultii) & erythroseptica & (2007) \\
Solanum brevideus & Pectobacterium spp. & Ahn et al. (2001) \\
\hline
\end{tabular}

beneficial effect of crop rotation depends on the host range of the pathogen and its ability to survive in soil in the absence of its host plant thanks to dormant structures such as sclerotia or chlamydospores. Crop rotation must avoid including alternative hosts for the pathogen (Peters et al. 2004). Susceptible weeds - such as hairy nightshade (Solanum sarrachoides) - have to be eliminated as they enable the pathogen to survive during the absence of the main host (Boydston et al. 2008). Crop rotation can also fail to control highly specialized pathogens, such as Globodera spp., $S$. endobioticum, or $S$. subterranea. These organisms are able to survive for long periods, either saprophytically or as dormant structures, in soil, and a very low inoculum density is sufficient to induce disease (Samaliev et al. 1998; Merz and Falloon 2009). Rotations with potatoes can include very diverse crops (Table 8). If some of those crops have beneficial effects towards potato crop, other might favor pathogen development and should not enter the rotation, or at least not as the crop preceding the potatoes.

\subsection{Fertilization and amendments}

Supplying plants with micronutrients and macronutrients can be achieved with organic or inorganic fertilizers, either through soil application, foliar spray, or seed treatment (Davis et al. 1994; Panique et al. 1997; Malakouti 2008). Adapted fertilization and amendment allow strong and healthy crops, which are less susceptible to pathogens (Khomyakov and Kostin 1981). Fertilization may also indirectly favor diseases by enhancing foliar development that maintains high level of humidity needed for example for the growth of Pectobacterium spp. (Rousselle et al. 1996). Amendments contribute to control diseases by modifying soil properties, especially $\mathrm{pH}$ (see Section 2.2) and microbial activities. That could result in specific suppression caused by the stimulated specific antagonistic populations or in general suppression caused by increased microbial activities or both (Lazarovits et al. 2001; Steinberg et al. 2007; Termorshuizen et al. 2006).

For some diseases, such as stem rot, organic fertilizers are more efficient than mineral ones in terms of disease suppression (Amitava and Maiti 2006; Table 8). Among organic fertlizers, composts are known to have the capacity to suppress diseases, depending on their degree of maturity (organic matter content and microbial activities). The causal agents of disease suppression brought into the soil by compost amendment are complexes of bacterial and fungal populations, which invade the pile during the curing stage, although some residual activity is probably related to fungistatic compounds occurring in the composts (Raviv 2008).

\subsection{Tillage management}

Potato cultivation traditionally involves intensive soil tillage throughout the cropping period. Mechanical tillage, ridging, and harvesting entail intensive soil disturbance and modify the environmental conditions especially the microbial characteristics of soil, both on quantitative and qualitative aspects (FAO 2008; Vian 2009). As an example, plowing contributes to redistribute vertically the inoculum, which increases the probability of infection (Taylor 2005). Over the last decades, there is a trend to replace plowing by techniques without soil inversion, i.e., no tillage or superficial tillage. It seems that this strategy could lead to some efficient disease suppression by stimulating microbial activity but conversely may limit the nutrient uptake by the plant (Klikocka 2001; Peters et al. 2004; Vian 2009). Therefore, a combination of both biotic and abiotic factors should be clearly balanced (Table 8). Indeed, rotation and conservation tillage practices can improve disease suppression by enhancing the antibiosis abilities of endophytic and root zone bacteria (Peters et al. 2003). On the other side, the plant growth and the macronutrient $(\mathrm{N}, \mathrm{P}, \mathrm{K}, \mathrm{Ca}$, and $\mathrm{Mg}$ ) contents in potato plant respond positively to a deeper soil caused by plowing (Boligowa and Glen 2003; Nunes et al. 2006).

\subsection{Planting, haulm destruction, lifting, and harvesting}

Planting, dehaulming, lifting, and harvesting are decisive for disease expression (Table 8). For example, low planting density increases the yield per plant because the foliage has more space to grow. Also, sparse plants are less exposed to 


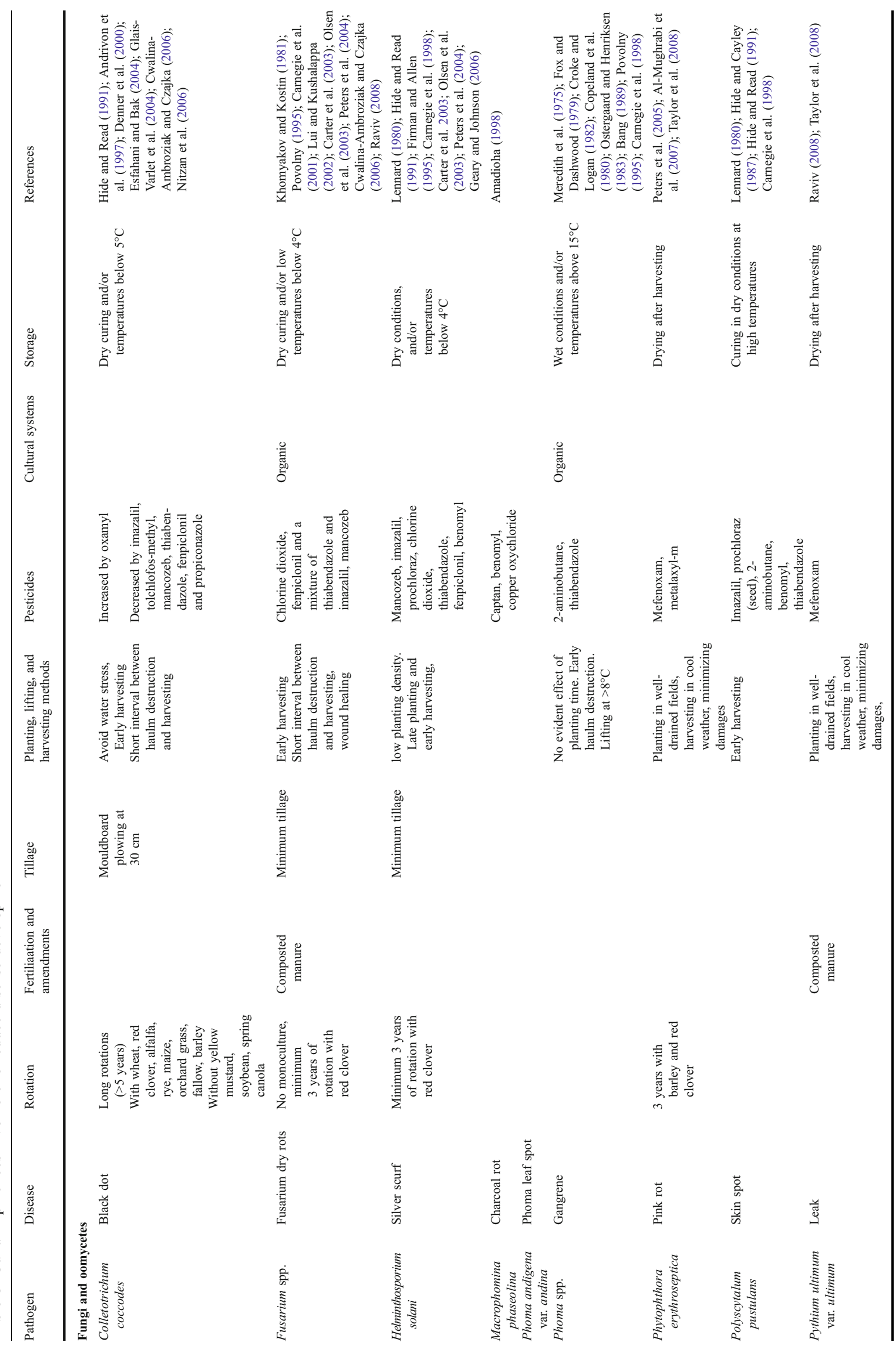




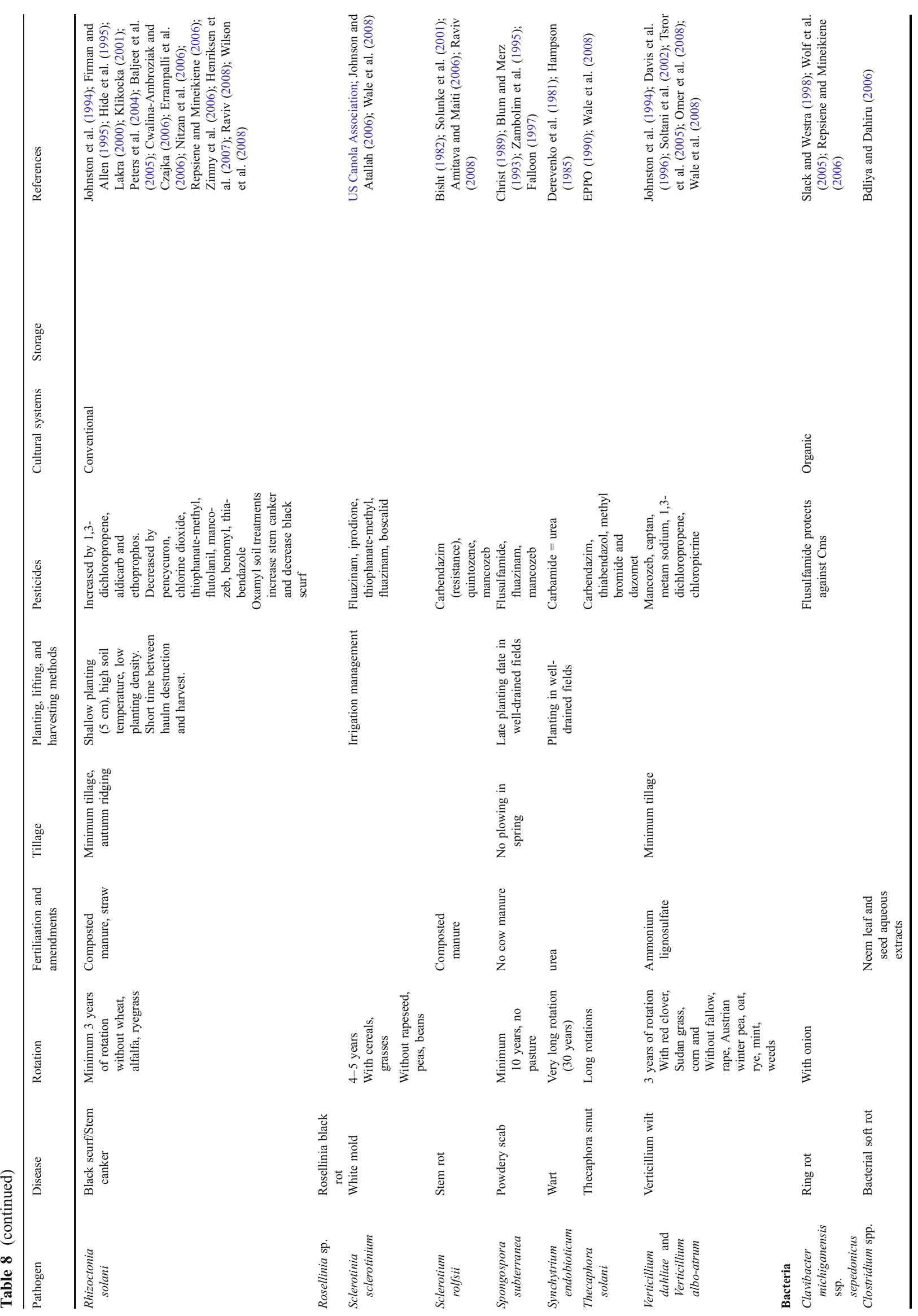




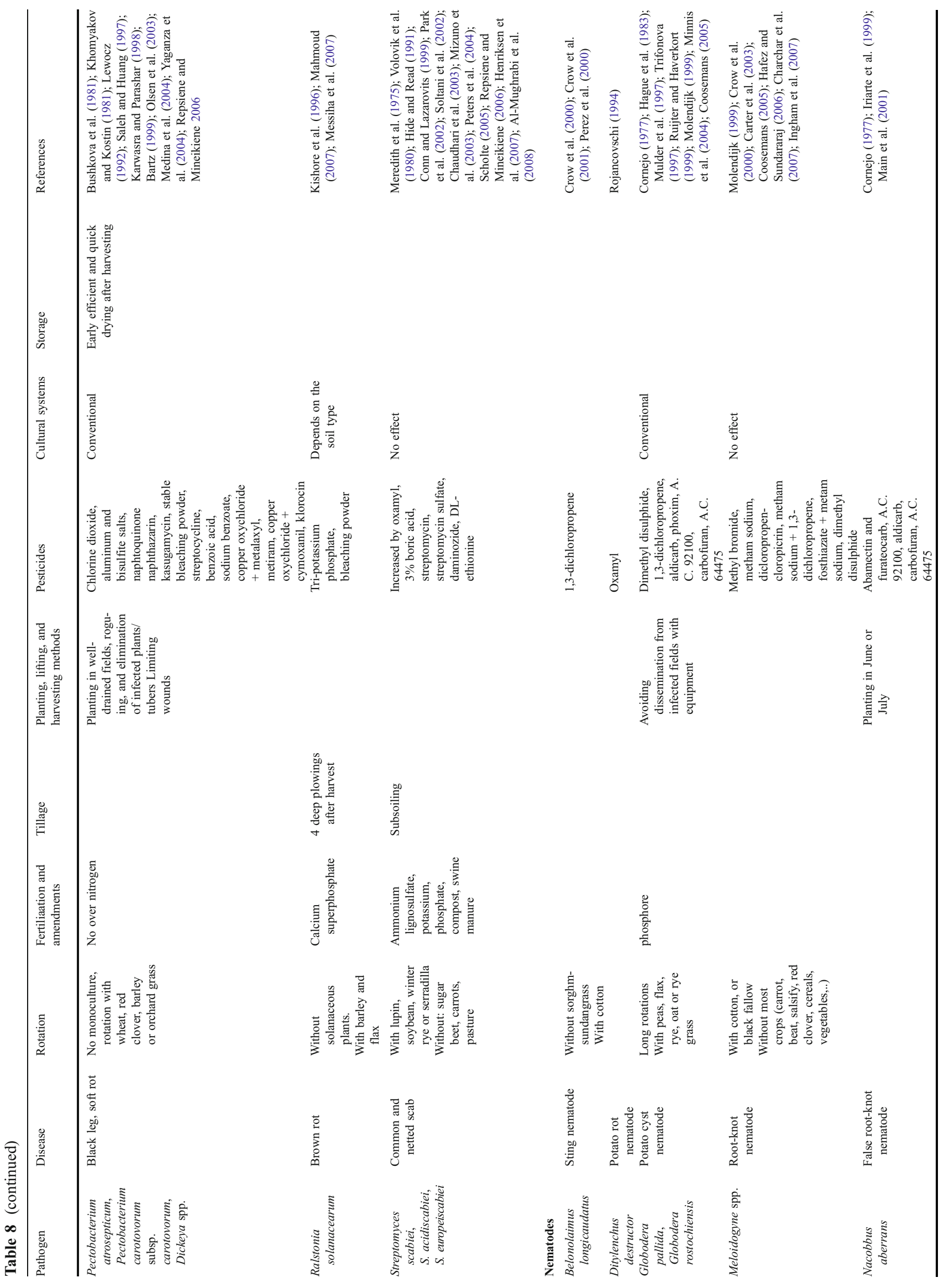




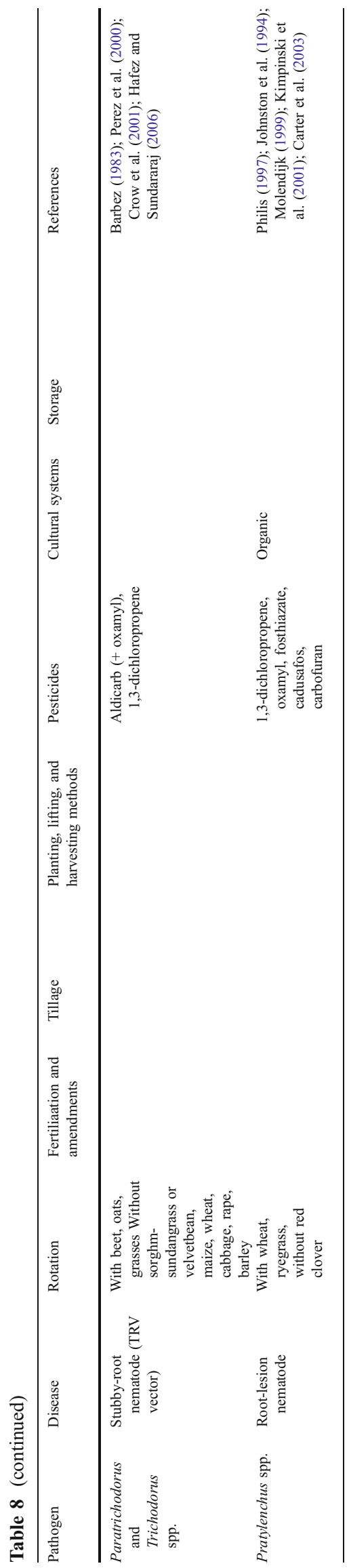

the attacks of pathogens than plants at high densities (Milic et al. 2006). Diseases can be reduced by adjusting planting, dehaulming, and harvesting dates and cultivation of early tuberizing cultivars combined with pre-harvesting desiccation of haulms and treatment of seed tubers with chemicals (Sikka and Singh 1976). Black scurf development on tubers has a positive correlation with the curing period (time between haulm destruction and harvest) because infection on tubers continues in the soil even after haulm destruction (Lakra 2000).

\subsection{Pesticides}

Pesticides are commonly used to control various pathogens altering potato tubers. They can be applied as soil fumigant (fumigants such as carbamates are not allowed in some European countries), sprayed or powdered directly on seed tubers after harvest or applied as granular (Hide et al. 1995; Tsror et al. 2000; Errampalli et al. 2006). The chemicals have to be carefully chosen, since pathogens can adapt and become resistant (Table 8). Thiabendazole-resistance was detected in Fusarium avenaceum, F. culmorum, F. equiseti, and $F$. sporotrichioides (Fusarium dry rot; Ocamb et al. 2007), in P. pustulans (skin spot; Carnegie et al. 2008) and in H. solani (silver scurf). Mefenoxam-resistance is known for P. erythroseptica (pink rot) populations (Taylor et al. 2006) and numerous treatments of carbendazim select resistant mutants of Sclerotium rolfsii (stem rot; Solunke et al. 2001). Moreover, the use of numerous chemicals is nowadays regulated and many of them are no longer permitted in Europe.

\subsection{Organic farming versus conventional agriculture}

Organic farming relies on agricultural techniques that exclude the use of chemical pesticides and recommend organic fertilization. As a result, the soil and tuber environment is quite different from the one caused by conventional practices and may induce disease suppression (Table 8). To reduce disease incidence or severity, the best adapted cultural system depends on the pathogen to control and varies strongly according to the soil type (Messiha et al. 2007). It has been reported that farmers who switch from conventional to organic system faced critical pest or disease problems during a transition period of about 5 years but managed to control soil-borne diseases on the long-term (Bruggen and Termorshuizen 2003). However, organic farmers generally faced more sanitary problems than conventional farmers.

\subsection{Handling and storage}

Inappropriate manipulation of tubers at harvest or during storage can provoke wounds that increase diseases such as 
black dot, Fusarium dry rots, silver scurf, gangrene, leak, pink rot, black leg, and soft rot (Meredith et al. 1975; Hide 1994; Vanvuurde and Devries 1994; Salas et al. 2000; Marcinkowska et al. 2005; Peters et al. 2008a, b; Table 8). Significant measures of managing potato diseases include: avoiding mechanical damage to potatoes during harvesting, shipping and sorting, curing the harmed parts thereby preventing infection and disease onset, avoiding manipulation of cold potato since potato tubers are more sensitive to injuries when cold, avoiding the exposure of table potato to light, and continuously providing stored potatoes with fresh air (Milosevic and Alovic 2006; Scheid 2006). Most of the storage diseases decrease when the tubers are cured in dry conditions and stored at temperature close to $4{ }^{\circ} \mathrm{C}$ or $5^{\circ} \mathrm{C}$, except gangrene (Table 8). Once again, for storage as for production, a balance between biotic and abiotic conditions should be carefully setup to preserve yield and quality. Indeed, despite they have less infection when stored in a dry atmosphere, tubers show greater weight losses than when they are stored in a humid atmosphere (Lennard 1980).

\section{Disease management}

\subsection{Risk assessment and decision support systems}

Disease occurrence and development influenced by abiotic and biotic factors are difficult to predict. However, their prediction would be very useful to assess disease risk and consequently the potential yield loss and to choose the best disease control strategy. Current methods to evaluate yield losses are based on predictive models which commonly assign a value or score to each risk factor, such as cultivar resistance, inoculum density, cultural practices, and environmental factors. The maximum score that can be assigned to each factor depends on the relative importance of the factor in determining the disease. For example, cultivar resistance is considered to be a major determinant of powdery scab severity, so this factor has a higher score than the zinc content of soil, which is thought to be less important (Burgess and Wale 1994). Assessment of the risk for each factor and for each disease is performed by bioassays in fields or in growth chambers under controlled conditions. They are generally laborious, time consuming, and costly.

Tolerant cultivars are a particular risk factor in potato production as they can maintain and increase the inoculum level in fields (Merz and Falloon 2009). A tolerance threshold of the crop has to be determined. It takes into account the relationship between inoculum density and disease incidence or severity according to cultivar resistance (Table 4).

A score can also be attributed to each cultural practice in the equation of the model since they have various impacts on yield losses. For example, incidence and severity of Verticillium wilt decrease with long rotations (Johnston et al. 1994), but mint as a previous crop increases Verticillium wilt (Omer et al. 2008). Consequently, in the equation of the model, rotation length will be negatively correlated to yield losses whereas mint as previous crop will be positively correlated to yield losses due to Verticillium wilt.

On the same pattern, some predictable environmental factors such as nutrient contents and soil $\mathrm{pH}$ can be scored. However, abiotic environmental factors are difficult to predict. For example, at planting time, rainfall and temperature conditions occurring at the critical growth phase of the disease are almost impossible to foresee. As climatic conditions cannot be predicted at middle term, models of risk assessment are less reliable. However, no factor alone has a dramatic effect on the disease; and the beneficial reduction of a disease is usually achieved by the sum of optimized factors (Harrison 1997).

Mathematical modeling including all the data related to the environmental factors and to the results concerning
Fig. 2 Input and output parameters of yield loss calculation models

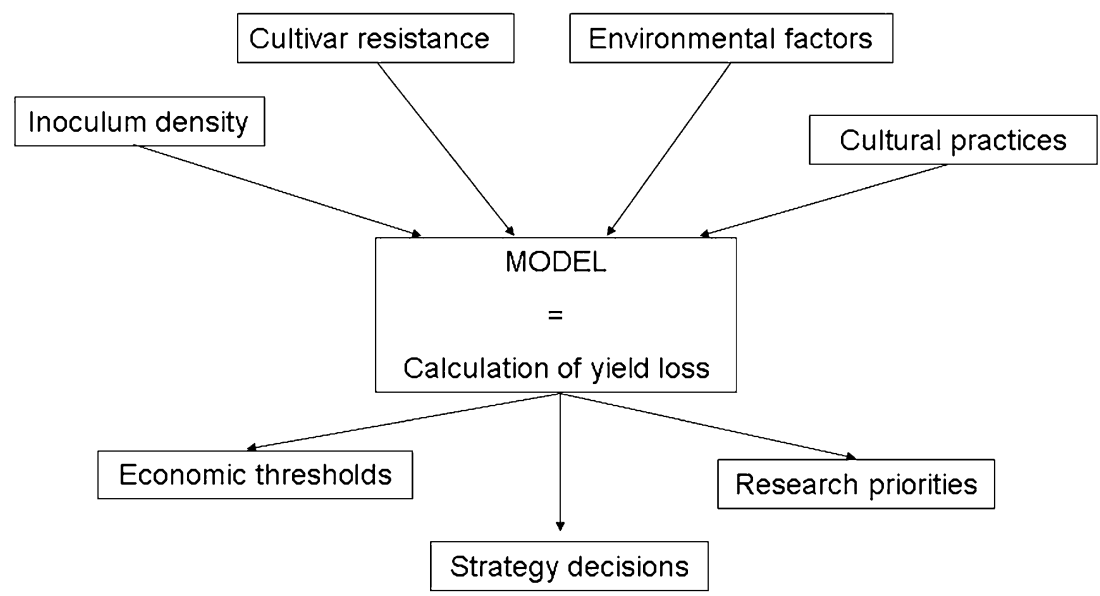


plant resistance appeared to be helpful to evaluate risk, to overcome the scaling gap between bioassays in growth chamber and field application and to simulate scenario based on crop management (Janvier et al. 2007).

Calculation of yield losses enables to identify a damage threshold and to determine the time at which disease control must be initiated. Indeed, yield loss threshold and economic threshold are different. Economic threshold is frequently higher than yield loss threshold; because up to a certain point, losing yield is less penalizing for farmers than spending money to avoid it. Calculation of economic thresholds beyond which control of diseases is profitable takes into account a damage function drift to potato yield, pathogen population density, and crop selling prices. For example, application of control measures is found to be beneficial at an initial density of $G$. rostochiensis higher than eight eggs and larvae per gram of soil, while the damage threshold is at two eggs per gram of soil (Samaliev and Andreev 1998). Economic thresholds allow taking short-term strategic decisions such as choice of the cultivar, cultural practices, timing of crop establishment, seed treatment, planting density, etc. and long-term strategic decisions such as define research priorities, design the breeding programs, or develop integrated pest management strategies (Savary et al. 2006) (Fig. 2). Predicting models are used by farmers as decision support systems (DSS) and generally provide a theoretical yield to be obtained at the end of the cropping period, a monitoring of pest populations and comments and advices in order to increase the theoretical yield as much as possible (Been et al. 2005; Jorg et al. 2006). Some DSS are able to send real time alerts to farmers when several risk factors are combined and when control measures have to be taken immediately (Dubois and Duvauchelle 2004). DSS are environmental and farmer friendly as they enable to increase economical yields by applying the right chemical doses at the right time and when disease pressure requires it, in order to reduce unnecessary environmental pollutions and treatment cost.

\subsection{Control methods}

Ways to control diseases are evolving since the use of chemicals is supposed to be reduced. In many cases, the most efficient long-term strategy is to use resistant cultivars when available. Otherwise, management strategies consist either in exclusion, avoiding contact between plant and pathogens, or by pest eradication, and leading to complete elimination or partial reduction of pathogen populations.

For the potato crop which is multiplied vegetatively, exclusion methods begin with the use of healthy tubers. Many soil-borne pathogens can be carried on by seed tubers and the use of certified seed potatoes is a major way to control or restrict the movement of pathogens of potato crops (Andrade et al. 2008). Seed certification programs aim at warranting seed tuber quality to potato producers and favor the diffusion of genetic progress. The certified seed production process may be $8-10$ years long. Strict rules established by the national regulation institutions (i.e., National Potato Council in USA or Groupement National Interprofessionnel des Semences-Service Officiel de Contrôle in France) have to be respected and the seeds are regularly inspected for bacterial, viral, and fungal diseases, as well as varietal purity and identity. Each country is free to apply more or less severe rules. Certification systems have been developed in most of the seed producing countries to cover the production of certified seed potatoes free from pathogens and pests (McDonald 1995; Grousset and Smith 1998; Sahajdak and Uznanska 2003). An international project of commercial and phytosanitary minimal guidelines (CEE-ONU S-1) is in progress. It is intended to serve as a minimal base consensus between the various standards established at "regional" levels (EU, NATTO, etc.; UNECE 2010).

Eradication strategies aim at eliminating an established pathogen from plant propagation material or production sites. Eradication methods involve the use of pesticides, adapted cultural practices or biological control. Application of fungicides and nematicides are protecting strategies (see Section 4.5 and Table 8) whose application time and doses can be advised by DSS. However, pesticides are sometimes inefficient against pathogens, such as Pectobacterium carotovorum (Latour et al. 2008), or their use is limited by environmental regulations. Consequently, alternative methods based on adapted cultural practices have to be recommended (see Section 4 and Tables 3 and 8). Some crops either susceptible or resistant may serve as baiting crop, for example, resistant potato cultivars cropped just before the main potato crop decreased black scurf (Scholte 2000). Likewise, alfalfa can be used to avoid TRV transmitted by stubby root nematode, as this crop is a host for stubby root nematode but immune to TRV (Stevenson et al. 2001). Cultivar precocity can be used to avoid some diseases. Since black dot and charcoal rot damages occur late in the growing season, early cultivars are generally recommended to control these diseases (Stevenson et al. 2001). When a disease is established in a production site, its spread must be avoided as much as possible. All diseased plants have to be eliminated or burned and tools should be properly disinfected before use in another field (Salas et al. 2000; Latour et al. 2008).

Natural interactions of plants and microorganisms with the pathogens are used as biological control to protect potato crops. There is a continuum from a conducive soil to a suppressive one (Alabouvette et al. 1996) what means that in each soil, almost each pathogen can be potentially controlled by other microorganisms either by a specific 
antagonism or by competition with total microbial biomass (see Section 3.2 and Table 6). Appropriate agricultural practices, thanks to the DSS, should stimulate this potential to enhance or to maintain the soil suppressiveness to potato diseases.

Another approach consists in applying biocontrol agents. However, the choice of a biological control agent must take into account the potential risks to human health. Even if Serratia grimesii and Burkholderia cepacia decrease dry rot and black scurf and stem canker, respectively, they can cause human infections and are not recommended for biological control (Table 6; Grosch et al. 2005; Gould et al. 2008). Moreover, indirect control such as strengthening of potato plants by mycorhization increases tuber yield and allow an integrated management of potato cyst nematode and root-knot nematode (Sankaranarayanan and Sundarababu 2001; Ryan et al. 2003). Biological control may also include the use of natural toxic compounds for pathogenic agents. Fumigation of essential oils is studied to control dry rot, gangrene, black scurf, and stem canker (Bang 2007). Fish emulsion and crushed crab shell are used against Verticillium dahliae, Verticillium albo-atrum, and S. endobioticum, respectively (Hampson and Coombes 1995; Abbasi et al. 2006). Soil can be disinfected from pathogens by biofumigation or solar heating or both. For example, Brassica crops used in crop rotations and as green manure have been associated with reductions in soil-borne pests and pathogens. These reductions have been attributed to the production of volatile sulfur compounds through the process of biofumigation and to changes in soil microbial community structure (Janvier et al. 2007). Composting is also a sanitizing method which combines temperature, time, and toxic compounds to control potato diseases. The composts the most frequently used on potato crop are organic wastes (sludge, manure, tea, etc.) that have undergone long, thermophilic and, aerobic decomposition. The most effective compost composition and combinations of temperature and time have to be determined for each pathogen. As it decreases the pathogenic population and/or favors microbial enrichment of the soil, compost has generally a positive or neutral effect on disease suppression and only rarely a disease stimulating effect (Termorshuizen et al. 2006). Sanitization is also performed on tubers before planting by hot water (Janvier et al. 2007) or during storage with chemical treatments at high temperatures (Secor et al. 1988). However, heating may damage tubers resulting in fewer sprouts. Biocontrol can also be performed by disrupting pathogens molecular pathways. P. carotovorum quorum-sensing mechanism is controlled by a quorum-quenching strategy aiming at interrupting the quorum-sensing by using compounds or organisms able to cause interferences in the bacterial signal (Latour et al. 2008). Finally, it is also possible to enhance plant defense reactions against soil-borne pathogens by foliar spraying with different inducers such as salicylic acid, di-potassium hydrogen phosphate, and tripotassium phosphate (Mahmoud 2007).

The different methods that were presented above are not items that have to be taken at random. Their combination generally gives better results than each of the method applied alone.

Decision support systems developed to predict yield losses allow choosing good control methods such as the use of healthy seeds, adapted pesticides, cultural practices, and biological control agents for each potato diseases.

\section{Conclusions}

If a disease results from the interaction between the plant and a pathogen, its severity is influenced by soil abiotic and biotic factors affecting the plant, the pathogen, or both (Alabouvette et al. 1996). Biotic and abiotic factors are not independent, the abiotic factors modulating the biotic ones. They act both on the disease epidemiology, that means the environmental conditions which make the plant growing and the pathogen, present or latent on the crop, causing or not the disease. Moreover, some unfavorable factors for a given disease can be favorable to another. The multifaceted interactions between plants, pathogens and their environment make disease management complex since controlling every factor occurring in the disease development is quite impossible. Potato producers have to aim at limiting contact between plant and pathogens by using for example healthy seeds. Moreover, pathosystems are continuously changing since the pathogens genetically adapt to their hosts or to the environmental conditions implemented by human activities or not. In a system whose parameters vary continuously, the control strategies have to be adapted to each situation at every time.

This review aimed at being as exhaustive as possible about the factors impacting the occurrence and development of the soil-borne potato diseases. Such a work putting in relation numerous potato diseases and comparing their development conditions, the ecology of the causal pathogens and their abiotic and biotic interactions responds to a clear demand from both scientists, extension services, breeders, and farmers. Studies dealing with potato diseases frequently consider only one or few diseases at the same time. Thus, this review constitutes by itself a decision support system since the optimal factors limiting disease development are listed. Nevertheless, the data collected here deal more with diseases known in developed counties and those which cause severe economical losses. Knowledge about minor diseases such as Phoma leaf spot, Rosellinia black rot, and Thecaphora smut are extremely rare, probably because these diseases occur in very isolated areas. Phoma leaf spot was 
recorded only in Bolivia and Peru, Rosellinia black rot was described in South America and Africa, and Thecaphora smut in South America and Mexico.

Moreover, soil-borne diseases are difficult to study because soil is a complex environment in which numerous interactions occur and where detection of pathogens is not easily performed. However, researches on those diseases could be beneficial at long-term in case they would spread throughout the world. It would have been rather complex to consider airborne diseases in addition to soil-borne diseases of potato. However, air-borne diseases such as late blight caused by Phytophthora infestans and early blight caused by Alternaria solani are responsible for huge economical losses and have to be considered with as much attention as soil-borne diseases. Finally, since few years, importance of potato tuber quality raised in developed countries where tubers are washed before selling. Indeed, washing tuber makes visible some superficial blemishes that were previously hidden by adhering soil. Consumer's habits changing, blemished tubers cannot be sold anymore and the losses take seriously damaging proportions for potato market.

The previous considerations acknowledge the fact that the plant disease problem can be reduced in short term thanks to solid knowledge in epidemiology and pathogens ecology; but in longer term, control strategies must be adapted with the constant evolution of pathosystems.

Acknowledgements Marie Fiers was financially supported by a $\mathrm{PhD}$ funding from the National Association of Technical Research (ANRT) (CIFRE $\left.n^{\circ} 1085 / 2006\right)$. This work was part of a Program of Collaborative Research (PRC) between Bretagne Plants and Germicopa, subsidized by the Regional Council of Brittany.

\section{References}

Abbasi PA, Conn KL, Lazarovits G (2006) Effect of fish emulsion used as a preplanting soil amendment on Verticillium wilt, scab, and tuber yield of potato. Canadian Journal of Plant PathologyRevue Canadienne De Phytopathologie 28:509-518

Abeln ECA, Stax AM, de Gruyter J, van der Aa HA (2002) Genetic differentiation of Phoma exigua varieties by means of AFLP fingerprints. Mycol Res 106:419-427. doi:10.1017/ s0953756202005804

Achenbach U, Paulo J, Ilarionova E, Lubeck J, Strahwald J, Tacke E, Hofferbert HR, Gebhardt C (2009) Using SNP markers to dissect linkage disequilibrium at a major quantitative trait locus for resistance to the potato cyst nematode Globodera pallida on potato chromosome V. Theor Appl Genet 118:619-629. doi:10.1007/s00122-008-0925-x

Adams MJ (1980) The role of seed tuber and stem inoculum in the development of gangrene in potatoes. Ann Appl Biol 96:17-28

Adams MJ, Read PJ, Lapwood DH, Cayley GR, Hide GA (1987) The effect of irrigation on powdery scab and other tuber diseases of potatoes. Ann Appl Biol 110:287-294
Ahn YK, Kang JC, Kim HY, Lee SD, Park HG (2001) Resistance to blackleg and tuber soft rot in interspecific somatic hybrids between S. brevidens and S. tuberosum ('Superior', 'Dejima', and dihaploid of 'Superior'). J Korean Soc Horticultural Sci 42:430-434

Al-Chaabi S, Matrod L (2002) Laboratory study to evaluate efficacy of different Trichoderma spp. isolates on some soil-borne pathogenic fungi. Arab J Plant Prot 20:77-83

Al-Hazmi AS, Ibrahim AAM, Abdul-Raziq AT (1993) Distribution, frequency and population density of nematodes associated with potato in Saudi Arabia. Afro Asian J Nematology 3:107-111

Al-Mughrabi KI, Bertheleme C, Livingston T, Burgoyne A, Poirier R, Vikram A (2008) Aerobic compost tea, compost and a combination of both reduce the severity of common scab (Streptomyces scabiei) on potato tubers. J Plant Sci 3:168-175

Al-Mughrabi KI, Peters RD, Platt HW, Moreau G, Vikram A, Poirier R, MacDonald I (2007) In-furrow applications of metalaxyl and phosphite for control of pink rot (Phytophthora erythroseptica) of potato in new brunswick. Can Plant Dis 91:1305-1309. doi:10.1094/pdis-91-10-1305

Alabouvette C, Hoeper H, Lemanceau P, Steinberg C (1996) Soil suppressiveness to diseases induced by soilborne plant pathogens. Soil Biochem 9:371-413

Alabouvette C, Raaijmakers J, De Boer W, Notz R, Défago G, Steinberg C, Lemanceau P (2006) Concepts and methods to assess the phytosanitary quality of soils. In: Bloem J, Hopkins DW, Benedetti A (eds) Plant-microbe interactions and soil quality handbook. CABI Publishing, Wallingford, pp 257-270

Amadioha AC (1997) Interaction of hydrolytic enzymes produced by Rhizoctonia bataticola during rot development. Acta Phytopathologica et Entomologica Hungarica 32:79-87

Amadioha AC (1998) Control of post harvest tuber rot of potato incited by Rhizoctonia bataticola. Arch Phytopathol Plant Prot 31:225-231

Amadioha AC, Adisa VA (1999) Microbial deterioration of potato tubers (Solanum tuberosum L.) in Nigeria. Afr J Root Tuber Crops 3:40-43

Amitava B, Maiti MK (2006) Role of host nutrition and varieties on the development of stem rot of potato. Ann Plant Prot Sci 14:479-480

Anaya GB, Perez NJ, Rodriguez D, Crozzoli R, Greco N (2005) Response of genetically improved potato clones to the cyst nematode, Globodera rostochiensis, and response of a resistant clone to the nematode in microplots. Nematropica 35:145-154

Andrade O, Munoz G, Galdames R, Duran P, Honorato R (2004) Characterization, in vitro culture, and molecular analysis of Thecaphora solani, the causal agent of potato smut. Phytopathology 94:875-882

Andrade SN, Contreras MA, Castro UI (2008) Effect of using certified and uncertified potato seeds on the yield and sanitary conditions of a potato crop. Agro Sur 36:63-66

Andrivon D, Ramage K, Guerin C, Lucas JM, Jouan B (1997) Distribution and fungicide sensitivity of Colletotrichum coccodes in French potato-producing areas. Plant Pathol 46:722-728

Anthoine G, Buisson A, Gauthier JP, Mugniery D (2006) Aspects of the biology of Nacobbus aberrans (Thorn 1935) Thorne and Allen 1944 (Nematoda: Pratylenchidae): 2-capacities of development on hosts under in vivo and in vitro conditions. Bull OEPP 36:365-372

Aqeel AM, Pasche JS, Gudmestad NC (2008) Variability in morphology and aggressiveness among North American vegetative compatibility groups of Colletotrichum coccodes. Phytopathology 98:901-909. doi:10.1094/phyto-98-8-0901

Atallah ZK, Bae J, Jansky SH, Rouse DI, Stevenson WR (2007) Multiplex real-time quantitative PCR to detect and quantify Verticillium dahliae colonization in potato lines that differ in 
response to Verticillium wilt. Phytopathology 97:865-872. doi:10.1094/phyto-97-7-0865

Atallah ZK, Stevenson WR (2006) A methodology to detect and quantify five pathogens causing potato tuber decay using realtime quantitative polymerase chain reaction. Phytopathology 96:1037-1045. doi:10.1094/phyto-96-1037

Atkins SD, Manzanilla-Lopez RH, Franco J, Peteira B, Kerry BR (2005) A molecular diagnostic method for detecting Nacobbus in soil and in potato tubers. Nematology 7:193-202

Aveskamp MM, De Gruyter J, Crous PW (2008) Biology and recent developments in the systematics of Phoma, a complex genus of major quarantine significance. Fungal Divers 31:1-18

Baard SW, Pauer GDC (1981) Effect of alternate drying and wetting of the soil fertilizer amendment and $\mathrm{pH}$ on the survival of micro sclerotia of Verticillium dahliae. Phytophylactica 13:165-168

Baayen RP, Bonthuis H, Withagen JCM, Wander JGN, Lamers JL, Meffert JP, Cochius G, van Leeuwen GCM, Hendriks H, Heerink BGJ, van den Boogert PHJF, van de Griend P, Bosch RA (2005) Resistance of potato cultivars to Synchytrium endobioticum in field and laboratory tests, risk of secondary infection, and implications for phytosanitary regulations. Bull OEPP 35:9-23

Baayen RP, Cochius G, Hendriks H, Meffert JP, Bakker J, Bekker M, van den Boogert P, Stachewicz H, van Leeuwen GCM (2006) History of potato wart disease in Europe-a proposal for harmonisation in defining pathotypes. Eur J Plant Pathol 116:21-31. doi:10.1007/s10658-006-9039-y

Back M, Haydock P, Jenkinson P (2006) Interactions between the potato cyst nematode Globodera rostochiensis and diseases caused by Rhizoctonia solani AG3 in potatoes under field conditions. Eur J Plant Pathol 114:215-223. doi:10.1007/ s10658-005-5281-y

Bae J, Atallah ZK, Jansky SH, Rouse DI, Stevenson WR (2007) Colonization dynamics and spatial progression of Verticillium dahliae in individual stems of two potato cultivars with differing responses to potato early dying. Plant Dis 91:1137-1141. doi:10.1094/pdis-91-9-1137

Bain RA, Lennard JH, Wastie RL (1987) The influence of cultivar and isolate on the development of gangrene (Phoma exigua var. foveata) in potato tubers. Ann Appl Biol 111:535-540

Bains PS, Bisht VS, Benard DA (1996) Soil survival and thiabendazole sensitivity of Helminthosporium solani isolates from Alberta. Can Potato Res 39:23-29

Baker KF (1970) Types of Rhizoctonia solani diseases and their occurence. In: Parmeter JRJ (ed) Rhizoctonia solani, biology and pathology symposium. University of California Press, Los Angeles, pp 125-148

Baker CJ, Whitaker BD, Mock NM, Rice CP, Roberts DP Deahl KL Ueng PP Aver'yanov, AA (2008) Differential induction of redox sensitive extracellular phenolic amides in potato. Physiological and Molecular Plant Pathology 73:109-115. doi: 10.1016/j. pmpp.2009.03.003

Baljeet S, Lakra BS, Ram N, Mahender S (2005) Influence of depth of planting on development of black scurf of potato (Rhizoctonia solani). Ann Biol 21:241-244

Bang U (1989) Cultivating measures for potatoes (Solanum tuberosum L.) and climatic factors affecting the gangrene pathogen Phoma foveata Foister, Vaxtskyddsrapporter, Avhandlingar, p 33

Bang U (2007) Screening of natural plant volatiles to control the potato (Solanum tuberosum) pathogens Helminthosporium solani, Fusarium solani, Phoma foveata and Rhizoctonia solani. Potato Res 50:185-203. doi:10.1007/s11540-008-9044-y

Banyal DK, Mankotia V, Sugha SK (2008) Soil characteristics and their relation to the development of tomato collar rot caused by Sclerotium rolfsii. Indian Phytopathol 61:103-107

Barbez D (1983) The distribution of virus-vector nematodes in seed-potato fields in Flanders (Belgium) and its relation to some biotic and abiotic factors. Mededelingen van de Faculteit Landbouwwetenschappen Rijksuniversiteit Gent 48:401-415

Bardin SD, Huang HC, Moyer JR (2004) Control of Pythium damping-off of sugar beet by seed treatment with crop straw powders and a biocontrol agent. Biol Control 29:453-460. doi:10.1016/j.biocontrol.2003.09.001

Bartz JA (1999) Suppression of bacterial soft rot in potato fibers by application of kasugamycin. Am J Potato Res 76:127-136

Bazan de Segura C, Carpio Rd (1974) Potato gangrene on the central Peruvian coast. Informe Ministerio de Agricultura, p 27

Been TH, Schomaker CH,Molendijk LPG (2005) NemaDecide: a decision support system for the management of potato cyst nematodes. In: Haverkort AJ and Struik PC (eds) Potato in progress: science meets practice, Potato 2005, Emmeloord, NL, 5-7 Sept 2005, pp 143-155

Bdliya BS, Dahiru B (2006) Efficacy of some plant extracts on the control of potato tuber soft rot caused by Erwinia carotovora ssp carotovora. J Plant Prot Res 46:285-294

Bharadwaj DP, Lundquist PO, Alstrom S (2008) Arbuscular mycorrhizal fungal spore-associated bacteria affect mycorrhizal colonization, plant growth and potato pathogens. Soil Biol Biochem 40:2494-2501. doi:10.1016/j.soilbio.2008.06.012

Bisht NS (1982) Control of Sclerotium rot of potato. Indian Phytopathol 35:148-149

Blum B, Merz U (1993) Occurrence of Spongospora subterranea, the causal agent of powdery scab disease of potatoes, in selected potato-producing areas. Landwirtschaft Schweiz 6:333-339

Blum LEB, Prada A, Medeiros EAA, Amarante CVTd (2002) Temperature, light and culture medium affecting the production of sclerotia of Sclerotium rolfsii and Sclerotinia sclerotiorum. Revista de Ciencias Agroveterinarias 1:27-32

Boligowa E, Glen K (2003) Yielding and quality of potato tubers depending on the kind of organic fertilisation and tillage method. Electronic Journal of Polish Agricultural Universities, Agronomy $6: 1-7$

Boogert PHJFVd, Gent-Pelzer MPEv, Bonants PJM, Boer SHd, Wander JGN, Levesque CA, Leeuwen GCMv, Baayen RP (2005) Development of PCR-based detection methods for the quarantine phytopathogen Synchytrium endobioticum, causal agent of potato wart disease. Eur J Plant Pathol 113:47-57. doi:10.1007/s10658-005-0297-x

Bouchek-Mechiche K, Gardan L, Andrivon D, Normand P (2006) Streptomyces turgidiscabies and Streptomyces reticuliscabiei: one genomic species, two pathogenic groups. Int J Syst Evol Microbiol 56:2771-2776. doi:10.1099/ijs.0.63161-0

Bouchek-Mechiche K, Pasco C, Andrivon D, Jouan B (2000) Differences in host range, pathogenicity to potato cultivars and response to soil temperature among Streptomyces species causing common and netted scab in France. Plant Pathol 49:3-10

Boydston RA, Mojtahedi H, Crosslin JM, Brown CR, Anderson T (2008) Effect of hairy nightshade (Solanum sarrachoides) presence on potato nematodes, diseases, and insect pests. Weed Sci 56:151-154. doi:10.1614/ws-07-035.1

Bradbury JF (1977) Erwinia carotovora var. atroseptica. [Descriptions of Fungi and Bacteria], IMI Descriptions of Fungi and Bacteria, Sheet 551

Brown MJ, Riedel RM, Rowe RC (1980) Species of Pratylenchus associated with Solanum tuberosum cv Superior in Ohio. J Nematology 12:189-192

Bruggen $\mathrm{AHCv}$, Termorshuizen $\mathrm{AJ}$ (2003) Integrated approaches to root disease management in organic farming systems. Australas Plant Pathol 32:141-156. doi:10.1071/ap03029

Burgess PJ, Wale SJ (1994) Development of an integrated control strategy for powdery scab of potatoes. Brighton Crop Protection Conference. Pest Dis 1-3:301-306 
Burlakoti RR, Estrada R, Rivera VV, Boddeda A, Secor GA, Adhikari TB (2007) Real-time PCR quantification and mycotoxin production of Fusarium graminearum in wheat inoculated with isolates collected from potato, sugar beet, and wheat. Phytopathology 97:835-841. doi:10.1094/phyto-97-7-0835

Bushkova LN, Shuvalova GV, Derzhipil'skii LM (1981) Some aspects of protection of potato and root cruciferous crops against bacterioses. Trudy Vsesoyuznogo Nauchno-Issledovatel'skogo Instituta Zashchity Rastenii, 71-74

Campion C, Chatot C, Perraton B, Andrivon D (2003) Anastomosis groups, pathogenicity and sensitivity to fungicides of Rhizoctonia solani isolates collected on potato crops in France. Eur J Plant Pathol 109:983-992

Carling DE, Baird RE, Gitaitis RD, Brainard KA, Kuninaga S (2002) Characterization of AG-13, a newly reported anastomosis group of Rhizoctonia solani. Phytopathology 92:893-899. doi:UNSPP2002-0604-01R

Carnegie SF (1991) The role of soil, seed-potato tuber and haulm in the transmission of Phoma foveata from infected seed to daughter tubers. Plant Pathol 40:352-358

Carnegie SF, Cameron AM, Haddon P (2001) The effect of date of haulm destruction and harvest on the development of dry rot caused by Fusarium solani var. coeruleum on potato tubers. Ann Appl Biol 139:209-216

Carnegie SF, Cameron AM, Haddon P (2008) Effects of fungicide and rate of application on the development of isolates of Polyscytalum pustulans resistant to thiabendazole and on the control of skin spot. Potato Res 51:113-129. doi:10.1007/s11540-0089094-1

Carnegie SF, Cameron AM, Lindsay DA, Sharp E, Nevison IM (1998) The effect of treating seed potato tubers with benzimidazole, imidazole and phenylpyrrole fungicides on the control of rot and skin blemish diseases. Ann Appl Biol 133:343-363

Carter MR, Kunelius HT, Sanderson JB, Kimpinski J, Platt HW, Bolinder MA (2003) Productivity parameters and soil health dynamics under long-term 2-year potato rotations in Atlantic Canada. Soil Tillage Res 72:153-168. doi:10.1016/s0167-1987 (03)00085-0

Chandel ST, Gaur HS, Alam MM (2002) Effect of tillage and water management on the population behaviour of root-knot nematodes Meloidogyne triticoryzae in rice crop. Arch Phytopathol Plant Prot 35:195-200

Chang RJ, Ries SM, Pataky JK (1992) Local sources of Clavibacter michiganensis ssp. michiganensis in the development of bacterial canker on tomatoes. Phytopathology 82:553-560

Charchar JM, Vieira JV, Oliveira VR, Moita AW (2007) Effects of fumigant and nonfumigant nematicides to control Meloidogyne spp. on potato and carrot. Nematologia Bras 31:59-66

Chaudhari SM, Patel RN, Khurana SMP, Patel RL, Patel NH (2003) Management of common scab of potato. J Indian Potato Assoc 30:135-136

Chowdary NB, Govindaiah (2007) Influence of different abiotic conditions on the growth and sclerotial production of Macrophomina phaseolina. Indian J Sericulture 46:186-188

Chowdhury N, Dey TK, Khan AL (1993) Effect of culture media, light, temperature and $\mathrm{pH}$ on the mycelial growth and sclerotia formation of Sclerotium rolfsii Sacc. Bangladesh J Bot 22:149153

Christ BJ (1989) Effect of planting date and inoculum level on incidence and severity of powdery scab on potato. Potato Res 32:419-424

Coelho RMS, De Castro HA, Menezes M (1997) Sporulation of Phomopsia and Phoma on different culture media, temperature and luminosity conditions. Summa Phytopathologica 23:176-180

Collins HP, Navare DA, Riga E, Pierce FJ (2006) Effect of foliar applied plant elicitors on microbial and nematode populations in the root zone of potato. Commun Soil Sci Plant Anal 37:17471759. doi: $10.1080 / 00103620600710538$

Combrink NJJ, Prinsloo KP, Jandrell AC (1975) The effect of calcium, phosphate and boron on the keeping quality and quality determining tuber characteristics of potatoes. Agroplantae 7:81-84

Conn KL, Lazarovits G (1999) Impact of animal manures on Verticillium wilt, potato scab, and soil microbial populations. Canadian Journal of Plant Pathology-Revue Canadienne De Phytopathologie 21:81-92

Coosemans J (2005) Dimethyl disulphide (DMDS): a potential novel nematicide and soil disinfectant. Proceedings of the VIth International Symposium on Chemical and Non-Chemical Soil and Substrate Disinfestation, 57-63

Copeland RB, Logan C, Little G (1980) Fungicidal control of potato black scurf. Tests of Agrochemicals and Cultivars (A supplement to Annals of Applied Biology, Vol. 94) 1:36-37

Cornejo QW (1977) Chemical control of Nacobbus aberrans and Globodera spp. Nematropica 7:6

Correll JC, Gordon TR, McCain AH (1988) Vegetative compatibility and pathogenicity of Verticillium albo-atrum. Phytopathology 78:1017-1021

Croke F, Logan C (1982) The effect of humidity on potato gangrene development in naturally contaminated tubers. Plant Pathol 31:61-64

Crow WT, Weingartner DP, Dickson DW (2000) Effects of potatocotton cropping systems and nematicides on plant-parasitic nematodes and crop yields. J Nematology 32:297-302

Crow WT, Weingartner DP, Dickson DW, McSorley R (2001) Effect of sorghum-sudangrass and velvetbean cover crops on plantparasitic nematodes associated with potato production in Florida. J Nematology 33:285-288

Cullen DW (2002) Detection of Colletotrichum coccodes from soil and potato tubers by conventional and quantitative real-time PCR. Plant Pathol 51:281-292

Cullen DW, Toth IK, Boonham N, Walsh K, Barker I, Lees AK (2007) Development and validation of conventional and quantitative polymerase chain reaction assays for the detection of storage rot potato pathogens, Phytophthora erythroseptica, Pythium ultimum and Phoma foveata. J Phytopathol 155:309-315

Cullen DW, Toth IK, Pitkin Y, Boonham N, Walsh K, Barker I, Lees AK (2005) Use of quantitative molecular diagnostic assays to investigate Fusarium dry rot in potato stocks and soil. Phytopathology 95:1462-1471. doi:10.1094/phyto-95-1462

Cunha MG, Rizzo DM (2004) Occurrence and epidemiological aspects of potato silver scurf in California. Horticultura Bras 22:690-695. doi:10.1590/s0102-05362004000400005

Cwalina-Ambroziak B, Czajka W (2006) Chemical control as a factor decreasing the infestation of potato tubers by pathogenic fungi. Prog Plant Prot 46:660-663

Davet P (1970) Recherches dur le Colletotrichum coccodes (Wallr.) Hugues. La phase non parasitaire. Cah ORSTOM Ser Biol 12:83-96

Davis JR, Huisman OC, Everson DO, Schneider AT (2001) Verticillium wilt of potato: a model of key factors related to disease severity and tuber yield in southeastern Idaho. Am J Potato Res 78:291-300

Davis JR, Huisman OC, Westermann DT, Hafez SL, Everson DO, Sorensen LH, Schneider AT (1996) Effects of green manures on Verticillium wilt of potato. Phytopathology 86:444-453

Davis JR, Stark JC, Sorensen LH, Schneider AT (1994) Interactive effects of nitrogen and phosphorus on Verticillium wilt of Russet Burbank potato. Am Potato J 71:467-481

Delleman J, Mulder A, Peeten JMG, Shipper E, Turkensteen LJ (2005) Potato diseases. NIVAP Holland; Aardappelwereld magazine

Denner FDN, Millard CP, Wehner FC (2000) Effect of soil solarisation and mouldboard ploughing on black dot of potato, caused by Colletotrichum coccodes. Potato Res 43:195-201 
Derevenko AS, Saltykova LP, Yakovleva VI, Pasechnik PS (1981) An experiment on the elimination of potato wart. Zashchita Rastenii, 44

Desgarennes D, Sanchez-Nava P, Pena-Santiago R, Carrion G (2009) Nematode fauna associated with the rhizosphere of potato crop (Solanum tuberosum) grown in the region of Cofre de Perote, Veracruz, Mexico. Revista Mexicana De Biodiversidad 80:611-614

Dey TK, Saha AK, Rahman M, Ali MS (2004) Biocontrol potential of Trichoderma spp. against Sclerotium rolfsii causing stem and tuber rot of potato. Bangladesh J Plant Pathol 20:31-34

Dhingra OD, Sinclair JB (eds) (1977) An annotated bibliography of Macrophomina phaseolina 1905-1975, Viçosa

Dieterich C, Sommer RJ (2009) How to become a parasite-lessons from the genomes of nematodes. Trends Genet 25:203-209. doi:10.1016/j.tig.2009.03.006

Dillard HR, Cobb AC (1998) Survival of Colletotrichum coccodes in infected tomato tissue and in soil. Plant Dis 82:235-238

Dong YH, Zhang XF, Xu JL, Zhang LH (2004) Insecticidal Bacillus thuringiensis silences Erwinia carotovora virulence by a new form of microbial antagonism, signal interference. Appl Environ Microbiol 70:954-960

Dubois L, Duvauchelle S (2004) Integrated control of potato late blight: MILPV, a new French decision support system. Phytoma 575:11-13

Eichenlaub R, Bermpohl A, Meletzus D (1991) Genetic and physiological aspects of the pathogenic interaction of Clavibacter michiganense subsp. michiganense with the host plant. Adv Mol Genet Plant Microbe Interact 1(10):99-102

El-Hassan KI, El-Saman MG, Mosa AA, Mostafa MH (2007) Variation among Fusarium spp. the causal of potato tuber dry rot in their pathogenicity and mycotoxins production. Egypt J Phytopathol 35:53-68

El Bakali AM, Martin MP (2006) Black scurf of potato. Mycologist 20:130-132

El Fahl AM, Calvert EL (1976) The effect of soil treatment with sulphur and lime on the incidence of potato diseases with special reference to blight. Rec Agric Res 24:7-12

Elson MK, Schisler DA, Bothast RJ (1997) Selection of microorganisms for biological control of silver scurf (Helminthosporium solani) of potato tubers. Plant Dis 81:647-652

EPPO (1990) Thecaphora solani. EPPO Bulletin, pp 1-3

EPPO (2008) Ditylenchus destructor and Ditylenchus dipsaci. EPPO Bulletin, pp 363-373

Errampalli D (2001) Emergence of silver scurf (Helminthosporium solani) as an economically important disease of potato. Plant Pathol 50:141-153

Errampalli D, Peters RD, MacIsaac K, Darrach D, Boswall P (2006) Effect of a combination of chlorine dioxide and thiophanatemethyl pre-planting seed tuber treatment on the control of black scurf of potatoes. Crop Prot 25:1231-1237. doi:10.1016/j. cropro.2006.03.002

Erukhimovitch V (2007) Early and rapid detection of potato's fungal infection by Fourier transform infrared microscopy. Appl Spectrosc 61:1052-1056

Esfahani AN, Bak AM (2004) Biological and cultural control of black dot disease of potato. J Sci Technol Agric Nat Resour 8:193-207

Falloon R (1997) Powdery scab control. Commercial Grower 52:16-18

FAO (2008) Available from: www.potato2008.org. Accessed on 19 Nov 2009

Ferreira EPdB, Dusi AN, Xavier GR, Rumjanek NG (2008) Rhizosphere bacterial communities of potato cultivars evaluated through PCR-DGGE profiles. Pesqui Agropecuaria Bras 43:605612. doi: $10.1590 / \mathrm{s} 0100-204 \times 2008000500008$

Ficke W, Naumann K, Skadow K, Muller HJ, Zielke R (1973) Longevity of Pectobacterium carotovorum var. atrosepticum (van Hall) Dowson on seed material and in the soil. Arch Phytopathologie Pflanzenschutz 9:281-293
Fiers M, Héraud C, Gautheron N, Chatot C, Le Hingrat Y, BouchekMechiche K, Steinberg C. Genetic diversity of Rhizoctonia solani associated with potato. Mycologia (in press)

Finetti SM (1990) Histopathological changes induced by Nacobbus aberrans in resistant and susceptible potato roots. Rev Nematologie 13:155-160

Firman DM, Allen EJ (1995) Transmission of Helminthosporium solani from potato seed tubers and effects of soil conditions, seed inoculum and seed physiology on silver scurf disease. J Agric Sci $124: 219-234$

Flores-Gonzalez R, Velasco I, Montes F (2008) Detection and characterization of Streptomyces causing potato common scab in Western Europe. Plant Pathol 57:162-169. doi:10.1111/ j.1365-3059.2007.01734.x

FNPPPT, GNIS (2000) Fiches descriptives des maladies et ravageurs de la pomme de terre. Ad Hoc, Paris

Fox RA, Dashwood EP (1979) Some effects of cultural practices for the control of potato gangrene. Bulletin, Scottish Horticultural Research Institute Association, 4-9

Fox RA, Dashwood EP, Wilson HM (1978) Biology of potato gangrene. Scottish Horticultural Research Institute, 24th Annual Report for the year 1977, pp 68-70

France RA, Brodie BB (1995) Differentiation of 2 New York isolates of Pratylenchus penetrans based on their reaction on potato. $\mathrm{J}$ Nematology 27:339-345

Franco CY, Stefanova NM, Coronado Izquierdo MF (2007) Pathogenicity and maceration ability of Pectobacterium carotovorum and Dickeya chrysanthemi isolates in potato (Solanum tuberosum L.). Fitosanidad 11:15-18

Franco J, Bendezu E (1985) Study of the complex Verticillium dahliae Kleb. and Globodera pallida Stone and its effect on the behaviour of some Peruvian potato cultivars. Fitopatologia 20:21-27

Franco J, Montecinos R, Ortuno N (1992) Management strategies of Nacobbus aberrans, Nematology from molecule to ecosystem: Proceedings Second International Nematology Congress, 11-17 August 1990, Veldhoven, the Netherlands, pp 240-248

Garibaldi A, Gilardi G, Gullino ML (2006) First report of southern blight incited by Sclerotium rolfsii on potato (Solanum tuberosum) in northern Italy. Plant Dis 90:1114-1114. doi:10.1094/pd-90-1114c

Geary B, Johnson DA (2006) Relationship between silver scurf levels on seed and progeny tubers from successive generations of potato seed. Am J Potato Res 83:447-453

Geary B, Johnson DA, Hamm PB, James S, Rykbost KA (2007) Potato silver scurf affected by tuber seed treatments and locations, and occurrence of fungicide resistant isolates of Helminthosporium solani. Plant Dis 91:315-320. doi:10.1094/ pdis-91-3-0315

Giebel J, DopieraLa U (2004) Pathogenesis of potato gangrene caused by Phoma exigua var. foveata: II. Activities of some hydrolases and dehydrogenases. J Phytopathol 152:399-403

Gilchrist E, Jaramillo VS, Reynaldi S (2009) Effect on the powdery scab of four isolates of the fungus Trichoderma asperellum in three types of soils. Revista-Facultad Nacional de Agronomia Medellin 62:4783-4792

Gilligan CA, Simons SA, Hide GA (1996) Inoculum density and spatial pattern of Rhizoctonia solani in field plots of Solanum tuberosum: effects of cropping frequency. Plant Pathol 45:232244

Gindrat D (1984) Storage rot of potato. II. Lesions development in relation to the parasitic species and temperature. Control measures. Revue Suisse d'Agriculture 16:313-318

Glais-Varlet I, Bouchek-Mechiche K, Andrivon D (2004) Growth in vitro and infectivity of Colletotrichum coccodes on potato tubers at different temperatures. Plant Pathol 53:398-404

Gould M, Nelson L, Waterer D, Hynes R (2008) Biocontrol of Fusarium sambucinum, dry rot of potato, by Serratia plymuthica 
5-6. Biocontrol Sci Technol 18:1005-1016. doi:10.1080/ 09583150802478189

Graaf Pvd, Lees AK, Cullen DW, Duncan JM (2003) Detection and quantification of Spongospora subterranea in soil, water and plant tissue samples using real-time PCR. Eur J Plant Pathol 109:589-597. doi:10.1023/a:1024764432164

Graaf Pvd, Lees AK, Wale SJ, Duncan JM (2005) Effect of soil inoculum level and environmental factors on potato powdery scab caused by Spongospora subterranea. Plant Pathol 54:2228. doi:10.1111/j.1365-3059.2005.01111.x

Grosch R, Faltin F, Lottmann J, Kofoet A, Berg G (2005) Effectiveness of 3 antagonistic bacterial isolates to control Rhizoctonia solani Kuhn on lettuce and potato. Can J Microbiol 51:345-353. doi:10.1139/w05-002

Grosch R, Scherwinski K, Lottmann J, Berg G (2006) Fungal antagonists of the plant pathogen Rhizoctonia solani: selection, control efficacy and influence on the indigenous microbial community. Mycol Res 110:1464-1474. doi:10.1016/j. mycres.2006.09.014

Grousset F, Smith IM (1998) EPPO certification scheme for seed potatoes. Bull OEPP 28:561-567

Gudmestad NC, Mallik I, Pasche JS, Anderson NR, Kinzer K (2009) A real-time PCR assay for the detection of Clavibacter michiganensis subsp sepedonicus based on the cellulase A gene sequence. Plant Dis 93:649-659. doi:10.1094/pdis-93-6-0649

Gudmestad NC, Taylor RJ, Pasche JS (2007) Management of soilborne diseases of potato. Australas Plant Pathol 36:109-115

Gupta CP, Sharma A, Dubey RC, Maheshwari DK (1999) Pseudomonas aeruginosa (GRC(1)) as a strong antagonist of Macrophomina phaseolina and Fusarium oxysporum. Cytobios 99:183-189

Gupta PP, Shekhar K, Yadav BD (2007) Effect of soil temperature and moisture levels on root rot of clusterbean. J Arid Legumes 4:95-99

Gvozdeva EL, Volotskaya AV, Sof' in AV, Kudryavtseva NN, Revina TA, Valueva TA (2006) Interaction of proteinases secreted by the fungal plant pathogen Rhizoctonia solani with natural proteinase inhibitors produced by plants. Appl Biochem Microbiol 42:502507. doi:10.1134/s0003683806050103

Hafez SL, Sundararaj P (2006) Efficacy of fosthiazate for the control of Paratrichodorus spp. and Meloidogyne chitwoodi on potato. Int J Nematology 16:157-160

Hague NGM, Damadzadeh M, Garabedian SK, Radwan KH (1983) Methods of assessing the efficacity of non-volatile nematicides. Pesticide Sci 14:587-595

Hampson MC (1985) Pathogenesis of Synchytrium endobioticum. 5. Wart disease suppression in potato in soils amended with urea and or ammonium-nitrate in relation to soil $\mathrm{pH}$. Plant Soil 87:241-250

Hampson MC, Coombes JW (1989) Pathogenesis of Synchytrium endobioticum 7. Earthworms as vector of wart disease of potato. Plant Soil 116:147-150

Hampson MC, Coombes JW (1995) Reduction of potato wart disease with crushed crabshell-suppression or eradication. Can J Plant Pathol Rev Can De Phytopathologie 17:69-74

Hampson MC, Coombes JW (1997) Pathogenesis of Synchytrium endobioticum.9. Effect of irrigation regimes and soil mixes on disease incidence with pathotype 2. Can J Plant Pathol Rev Can De Phytopathologie 19:47-51

Hampson MC, Coombes JW, McRae KB (1994) Pathogenesis of Synchytrium endobioticum. 8. Effect of temperature and resting spore density (pathotype 2) on incidence of potato wart disease. Can J Plant Pathol Rev Can De Phytopathologie 16:195-198

Harikrishnan R, del Rio LE (2006) Influence of temperature, relative humidity, ascospore concentration, and length of drying of colonized dry bean flowers on white mold development. Plant Dis 90:946-950. doi:10.1094/pd-06-0946
Harrison JG (1997) Powdery scab disease of potato - a review. Plant Pathol 46:1-25

Heath WL, Haydock PPJ, Wilcox A, Evans K (2000) Monitoring the presence and distribution of potato cyst nematodes: the potential use of light reflected from the crop. Asp Appl Biol 56:127-130

Heilmann LJ, Nitzan N, Johnson DA, Pasche JS, Doetkott C, Gudmestad NC (2006) Genetic variability in the potato pathogen Colletotrichum coccodes as determined by amplified fragment length polymorphism and vegetative compatibility group analyses. Phytopathology 96:1097-1107. doi:10.1094/phtyo-96-1097

Helias V (2008) Pectobacterium spp. and Dickeya spp. on potato: a new nomenclature for Erwinia spp., symptoms, epidemiology and disease prevention. Cahiers Agricultures 17:349-354. doi:10.1684/agr.2008.0216

Helias V, Andrivon D, Jouan B (2000) Internal colonization pathways of potato plants by Erwinia carotovora ssp atroseptica. Plant Pathol 49:33-42

Henriksen CB, Molgaard JP, Rasmussen J (2007) The effect of autumn ridging and inter-row subsoiling on potato tuber yield and quality on a sandy soil in Denmark. Soil Tillage Res 93:309315. doi:10.1016/j.still.2006.05.003

Hide GA (1994) Effects of wounding fungicide-treated potato seed tubers on silver scurf disease on daughter tubers at harvest. Potato Res 37:287-290

Hide GA, Cayley GR (1987) Effects of delaying fungicide treatment and of curing and chloropropham on the incidence of skin spot on stored potato tubers. Ann Appl Biol 110:617-627

Hide GA, Firmager JP (1989) Effects of soil temperature and moisture on stem canker (Rhizoctonia solani) disease of potatoes. Potato Res 32:75-80

Hide GA, Read PJ (1991) Effects of rotation length, fungicide treatment of seed tubers and nematicide on diseases and the quality of potato tubers. Ann Appl Biol 119:77-87

Hide GA, Welham SJ, Read PJ, Ainsley AE (1995) Influence of planting seed tubers with gangrene (Phoma foveata) and of neighboring healthy, diseased and missing plants on the yield and size of potatoes. J Agric Sci 125:51-60

Hiemstra JA, Rataj-Guranowska M (2003) Vegetative compatibility groups in Verticillium dahliae isolates from the Netherlands as compared to VCG diversity in Europe and in the USA. Eur J Plant Pathol 109:827-839

Hims MJ, Preece TF (1975) Spongospora subterranea f.sp. subterranea. IMI Descriptions of Fungi and Bacteria, Sheet 477

Hlaoua W, Raouani NH (2007) Effect of Meloidogyne incognita on the potato crop. Nematologia Mediterr 35:213-220

Holgado R, Skau KAO, Magnusson C (2009) Field damage in potato by lesion nematode Pratylenchus penetrans, its association with tuber symptoms and its survival in storage. Nematologia Mediterr $37: 25-29$

Höper H, Alabouvette C (1996) Importance of physical and chemical soil properties in the suppressiveness of soils to plant diseases. Eur J Soil Biol 32:41-58

Hsu ST (1991) Ecology and control of Pseudomonas solanacearum in Taiwan. Plant Prot Bull Taichung 33:72-79

Hughes J (2008) Molecular diagnostics and their importance for Rhizoctonia solani control in potatoes. Outlooks Pest Manage 19:123-126. doi:10.1564/19jun08

Hukkanen A, Karjalainen R, Nielsen SL, van der Wolf JM (2005) Epidemiology of Clavibacter michiganensis subsp sepedonicus in potato under European conditions: population development and yield reduction. Z Fur Pflanzenkrankheiten Und Pflanzenschutz J Plant Dis Prot 112:88-97

Ilyashenka D, Ivaniuk V (2008) Potato stem nematode in Belarus. Zemdirbyste Agric 95:74-81

Ingham RE, Hamm PB, Baune M, David NL, Wade NM (2007) Control of Meloidogyne chitwoodi in potato with shank- 
injected metam sodium and other nematicides. J Nematology 39:161-168

INRA, Cemagref (2005) Réduire l'utilisation des pesticides et en limiter les impacts environnementaux. Ministère de l'agriculture et de la pêche, Ministère de l'écologie et du développement durable, pp 68

Inserra RN, Chitambar JJ, Chitwood DJ, Handoo Z (2005) The Potato Pathotype of the False-Root Knot Nematode, Nacobbus aberrans. Working Group of the SON Exotic Nematode Plant Pest List, p 10

Inserra RN, McSorley R, Greco N, Weingartner DP (1996) Potato cyst nematodes, a potential menace to the potato industry of Florida. Soil and Crop Science Society of Florida Proceedings 55:1-5

IPC (1978) Annual report for 1977 International Potato Center, Lima, Peru, pp 156

Iriarte L, Franco J, Ortuno N (1999) Influence of time of sowing on potato yield and population density of Nacobbus aberrans. Fitopatologia 34:77-82

Jaggi W, Oberholzer H, Winiger FA (1991) Effect of harvesting and storage conditions on infection of potatoes by Erwinia carotovora. Kartoffelbau 42:474-480

Jansky SH, Rouse DI (2003) Multiple disease resistance in interspecific hybrids of potato. Plant Dis 87:266-272

Janvier C, Villeneuve F, Alabouvette C, Edel-Hermann V, Mateille T, Steinberg C (2007) Soil health through soil disease suppression: which strategy from descriptors to indicators? Soil Biol Biochem 39:1-23

Jauhari RK, Lal M (2001) Effect of soil moisture on the population of migratory nematode Pratylenchus penetrans (Cobb 1917) (Nematoda: Hoplolamidae) on tea plantations in Doon Valley. J Parasitol Appl Anim Biol 10:1-8

Jensen HJ (1978) Interrelations of nematodes and other organisms in disease complexes, International Potato Center. Report of the 2nd planning conference on the developments in the control of nematode pests of potatoes, Lima, Peru, 13-17 November 1978, pp $154-160$

Joaquim TR, Rowe RC (1991) Vegetative compatibility and virulence of strains of Verticillium dahliae from soil and potato plants. Phytopathology 81:552-558

Johnson DA, Atallah ZK (2006) Timing fungicide applications for managing Sclerotinia stem rot of potato. Plant Dis 90:755-758. doi:10.1094/pd-90-0755

Johnston HW, Celetti MJ, Kimpinski J, Platt HW (1994) Fungal pathogens and Pratylenchus penetrans associted with preceding crops of clovers, winter-wheat, and annual ryegrass and their influence on succeeding potato crops on Prince Edward Island. Am Potato J 71:797-808

Jong-Tae K, In-Hee P, Hyang-Burm L, Young-Il H, Seung-Hun Y (2001) Identification of Verticillium dahliae and $V$. albo-atrum causing wilt of tomato in Korea. Plant Pathol J 17:222-226

Kamensky M, Ovadis M, Chet I, Chernin L (2002) Biocontrol of Botrytis cinerea and Sclerotinia sclerotiorum in the greenhouse by a Serratia plymuthica strain with multiple mechanisms of antifungal activity. Bull OILB SROP 25:229-232

Kandji ST, Ogol C, Albrecht A (2001) Diversity of plant-parasitic nematodes and their relationships with some soil physicochemical characteristics in improved fallows in western Kenya. Appl Soil Ecol 18:143-157

Kang HC, Park YH, Go SJ (2003) Growth inhibition of a phytopathogenic fungus, Colletotrichum species by acetic acid. Microbiol Res 158:321-326

Karwasra SS, Parashar RD (1998) Chemical control of incipient infection, weight loss and sprouting of potato tubers during storage. Plant Dis Res 13:49-51

Keshwal RL, Khare UK, Singh RP (2000) Effect of physical properties of soil on wilt incidence and population of Ralstonia solanacearum. Ann Plant Prot Sci 8:40-43
Khomyakov MT, Kostin NP (1981) The effects of potato saturation in rotations and of dosage rates of fertilizers on the development of diseases of tubers in storage. Trudy Vsesoyuznogo NauchnoIssledovatel'skogo Instituta Zashchity Rastenii, 66-70

Kim-Lee HY, Moon JS, Hong YJ, Kim MS, Cho HM (2005) Bacterial wilt resistance in the progenies of the fusion hybrids between haploid of potato and Solanum commersonii. Am J Potato Res 82:129-137

Kim MH, Park SC, Kim JY, Lee SY, Lim HT, Cheong H, Hahm KS, Park Y (2006) Purification and characterization of a heat-stable serine protease inhibitor from the tubers of new potato variety "Golden Valley". Biochem Biophys Res Commun 346:681-686. doi:10.1016/j.bbrc.2006.05.186

Kimpinski J, Arsenault WJ, Sturz AV (2001) Differential effect of nematicide treatments on tuber yields in early- and late-maturing potato cultivars. Plant Pathol 50:509-514

Kishore V, Shekhawat GS, Sunaina V (1996) Cultural practices to reduce Pseudomonas solanacearum in the infested soil. J Indian Potato Assoc 23:130-133

Klikocka H (2001) The influence of soil tillage systems and crop cultivation methods on potato tubers infection with Rhizoctonia solani Kuhn. Biuletyn Instytutu Hodowli i Aklimatyzacji Roslin, 243-247

Kong Q, Yuan S, Wang Y, Zhu Y (2006) Study on biological characteristics of Fusarium solani on Vanilla planifolia root. J Mt Agric Biol 25:506-509

Krechel A, Faupel A, Hallmann J, Ulrich A, Berg G (2002) Potatoassociated bacteria and their antagonistic potential towards plantpathogenic fungi and the plant-parasitic nematode Meloidogyne incognita (Kofoid \& White) Chitwood. Can J Microbiol 48:772786. doi: $10.1139 / \mathrm{w} 02-071$

Kumar S, Vadivelu S (1996) Influence of soil type on the interaction between root-knot nematode, reniform nematode and root-rot in eggplant. Pest Manage Horticultural Ecosyst 2:29-35

Kumar SM, Khare MN (1990) Studies on the antagonistic relationship of soybean spermosphere microflora with Rhizoctonia bataticola and Sclerotium rolfsii. J Biol Control 4:72-74

Kuninaga S, Carling DE, Takeuchi T, Yokosawa R (2000) Comparison of rDNA-ITS sequences between potato and tobacco strains in Rhizoctonia solani AG-3. J Gen Plant Pathol 66:2-11

Lakra BS (2000) Effect of planting time and curing period on black scurf development and yield of potato. Haryana J Horticultural Sci 29:121-122

Lambert DH, Manzer FE (1991) Relationship of calcium to potato scab. Phytopathology 81:632-636

Lambert DH, Reeves AF, Goth RW, Grounds GS, Giggie EA (2006) Relative susceptibility of potato varieties to Streptomyces scabiei and $S$. acidiscabies. Am J Potato Res 83:67-70

Larkin RP (2008) Relative effects of biological amendments and crop rotations on soil microbial communities and soilborne diseases of potato. Soil Biol Biochem 40:1341-1351. doi:10.1016/j.soilbio. 2007.03.005

Latour X, Faure D, Diallo S, Cirou A, Smadja B, Dessaux Y, Orange N (2008) Control of bacterial diseases of potato caused by Pectobacterium spp. (Erwinia carotovora). Cahiers Agricultures 17:355-360. doi:10.1684/agr.2008.0210

Laurila J, Metzler MC, Ishimaru CA, Rokka VM (2003) Infection of plant material derived from Solanum acaule with Clavibacter michiganensis ssp sepedonicus: temperature as a determining factor in immunity of $S$. acaule to bacterial ring rot. Plant Pathol $52: 496-504$

Lazarovits G, Hill J, Patterson G, Conn KL, Crump NS (2007) Edaphic soil levels of mineral nutrients, $\mathrm{pH}$, organic matter, and cationic exchange capacity in the geocaulosphere associated with potato common scab. Phytopathology 97:1071-1082. doi:10.1094/phyto-97-9-1071 
Lazarovits G, Tenuta M, Conn KL (2001) Organic amendments as a disease control strategy for soilborne diseases of high-value agricultural crops. Australas Plant Pathol 30:111-117

Lazy GH, Lukezic FL (2003) Pathogenic prokaryotes. In: Trigiano RN, Windham MT, Windham AS (eds) Plant pathology. CRC Press, New York

Lees AK (2003) Black dot (Colletotrichum coccodes): an increasingly important disease of potato. Plant Pathol 52:3-12

Lees AK, Cullen DW, Sullivan L, Nicolson MJ (2002) Development of conventional and quantitative real-time PCR assays for the detection and identification of Rhizoctonia solani AG-3 in potato and soil. Plant Pathol 51:293-302

Lees AK, Sullivan L, Cullen DW (2009) A quantitative polymerase chain reaction assay for the detection of Polyscytalum pustulans, the cause of skin spot disease of potato. J Phytopathol 157:154158. doi:10.1111/j.1439-0434.2008.01459.x

Lehtonen MJ, Somervuo P, Valkonen JPT (2008) Infection with Rhizoctonia solani induces defense genes and systemic resistance in potato sprouts grown without light. Phytopathology 98:11901198. doi:10.1094/phyto-98-11-1190

Lennard JH (1980) Factors affecting the development of silver scurf (Helminthosporium solani) on potato-tubers. Plant Pathol 29:87-92

Lerat S, Babana AH, El OM, El HA, Daayf F, Beaudoin N, Bouarab K, Beaulieu C (2009) Streptomyces scabiei and its toxin thaxtomin A induce scopoletin biosynthesis in tobacco and Arabidopsis thaliana. Plant Cell Report 28:1895-1903. doi: 10.1007/s00299-009-0792-1

Levine A, Tenhaken R, Dixon R, Lamb C (1994) H2O2 from the oxidative burst orchestrates the plant hypersensitive disease resistance response. Cell 79:583-593

Lewocz W (1992) Activity of some fungicides as limiting factors of black leg and soft rot of potato tubers. Biuletyn Instytutu Ziemniaka, pp 89-96

Li W, Roberts DP, Dery PD, Meyer SLF, Lohrke S, Lumsden RD, Hebbar KP (2002) Broad spectrum anti-biotic activity and disease suppression by the potential biocontrol agent Burkholderia ambifaria BC-F. Crop Prot 21:129-135

Liu H, Coulthurst SJ, Pritchard L, Hedley PE, Ravensdale M, Humphris S, Burr T, Takle G, Brurberg MB, Birch PRJ, Salmond GPC, Toth IK (2008) Quorum sensing coordinates brute force and stealth modes of infection in the plant pathogen Pectobacterium atrosepticum. Plos Pathogens. doi:10.1371/journal. ppat. 1000093

Lo C, Wang K (2000) Factors affecting pycnidial production and pycnidiospore germination of Phoma wasabiae, the causal agent of wasabi. Plant Pathol Bull 9:99-106

Logan C, O'Neill R, McGrane P, Little G (1987) Methods for detection of the blackleg ring rot and gangrene pathogens in potato nuclear stock mother tubers and plantlets. Bull OEPP 17:17-24

Loria R, Bignell DRD, Moll S, Huguet-Tapia JC, Joshi MV, Johnson EG, Seipke RF, Gibson DM (2008) Thaxtomin biosynthesis: the path to plant pathogenicity in the genus Streptomyces. Antonie Van Leeuwenhoek International J Gen Mol Micro 94:3-10. doi:10.1007/s10482-008-9240-4

Loria R, Bkhalid RA, Fry BA, King RR (1997) Plant pathogenicity in the genus Streptomyces. Plant Disease 81:836-846

Lucas JA, Pitt D (1974) Immunochemical identification of a new molecular form of acid-phosphatase of host origin arising during infection of potato tubers by Phytophthora erythroseptica Pethybr. J Gen Microbiol 84:311-320

Lucke W (1975) The effect of additional sprinkler irrigation and its combination with nitrogen supply on the occurrence of potato blackleg (Pectobacterium carotovorum (Jones) Waldee var. atrosepticum (van Hall) Dowson). Arch Phytopathologie Pflanzenschutz 11:213-223
Lui LH (2003) Models to predict potato tuber infection by Pythium ultimum from duration of wetness and temperature, and leaklesion expansion from storage duration and temperature. Postharvest Biol Technol 27:313-322

Lui LH, Kushalappa AC (2002) Response surface models to predict potato tuber infection by Fusarium sambucinum from duration of wetness and temperature, and dry rot lesion expansion from storage time and temperature. Int J Food Microbiol 76:19-25

Lulai EC (2001) In: Stevenson WR, Loria R, Franc GD, Weingartner DP (eds) Compendium of potato diseases. APS Press, St. Paul, p 3

Lutomirska B, Szutkowska M (2005) Influence of the soil type and date of irrigation on tuber infection with Rhizoctonia solani (Kuhn). Prog Plant Prot 45:865-868

Lyon GD (1989) The biochemical basis of resistance of potatoes to soft rot Erwinia spp. : a review. Plant Pathology 38:313-339

Madalageri BB, Dharmatti PR, Hosmani RM, Srikant K (1991) Varietal resistance of potato to wilt caused by Sclerotium rolfsii Sacc. Curr Res Univ Agric Sci Bangalore 20:26-27

Mahmoud DAR, Mahmoud AA, Gomaa AM (2008) Antagonistic activities of potato associated bacteria via their production of hydrolytic enzymes with special reference to pectinases. Res J Agric Biol Sci 4:575-584

Mahmoud SM (2007) Management of brown rot disease of potato. Arab Universities J Agric Sci 15:457-463

Main G, Franco J, Ortuno N (2001) Disinfection of potato seed infected with Nacobbus aberrans using mild nematicides. Manejo Integrado de Plagas, 52-57

Malakouti MJ (2008) The effect of micronutrients in ensuring efficient use of macronutrients. Turk J Agric For 32:215-220

Manici LM, Caputo F (2009) Fungal community diversity and soil health in intensive potato cropping systems of the east Po valley, northern Italy. Ann Appl Biol 155:245-258. doi:10.1111/j.17447348.2009.00335.x

Marcinkowska J, Roze-Kauzny I, Kauzny W (2005) Pathogenicity of some Phoma exigua var. exigua isolates. Phytopathol Pol 38; 35-44

Marshall KC (1975) Clay mineralogy in relation to survival of soil bacteria. Annu Rev Phytopathol 13:357-373

Martinez C, Rioux D, Tweddell RJ (2004) Ultrastructure of the infection process of potato tuber by Helminthosporium solani, causal agent of potato silver scurf. Mycol Res 108:828-836. doi:10.1017/s0953756204000589

Mashela P, McSorley R, Duncan LW, Dunn RA (1991) Correlation of Belonolaimus longicaudatus, Hoplolaimus galeatus, and soil texture with yield of alyceclover (Alysicarpus spp.). Nematropica $21: 177-184$

McDonald JE, White GP, Cote MJ (2000) Differentiation of Phoma foveata from $P$. exigua using a RAPD generated PCR-RFLP marker. Eur J Plant Pathol 106:67-75

McDonald JG (1995) Disease control through crop certification: herbaceous crops. Can J Plant Pathol Rev Can De Phytopathologie 17:267-273

Medina LFC, Stefani V, Brandelli A (2004) Use of 1,4-naphthoquinones for control of Erwinia carotovora. Can J Microbiol 50:951-956. doi:10.1139/w04-088

Mehta SK, Tripathi NN, Rakesh K, Chhabra ML (2006) Influence of light and temperature on induction of pycnidia and germination of pycnidiospores. Ann Biol 22:31-34

Melakeberhan H, Dey J, Baligar VC, Carter TE (2004) Effect of soil $\mathrm{pH}$ on the pathogenesis of Heterodera glycines and Meloidogyne incognita on Glycine max genotypes. Nematology 6:585-592

Melakeberhan H, Mennan S, Chen S, Darby B, Dudek T (2007) Integrated approaches to understanding and managing Meloidogyne hapla populations' parasitic variability. Crop Prot 26:894902. doi:10.1016/j.cropro.2006.08.008 
Meredith DS, Logan C, Copeland RB, Meijers CP, Henriksen JB, McIntosh AH (1975) Session 8C. Control of fungal diseases of potatoes. Proceedings of the Eighth British Insecticide and Fungicide Conference, Brighton, England, 17-20 November, 1975. Vols. 1 and 2, Research Reports, pp 581-623

Merz U (2005) Improved immunological detection of Spongospora subterranea. Eur J Plant Pathol 111:371-379

Merz U, Falloon RE (2009) Review: powdery scab of potatoincreased knowledge of pathogen biology and disease epidemiology for effective disease management. Potato Res 52:17-37. doi:10.1007/s11540-008-9105-2

Messiha NAS, Bruggen AHCv, Diepeningen ADv, Vos OJd, Termorshuizen AJ, Tjou-Tam-Sin NNA, Janse JD (2007) Potato brown rot incidence and severity under different management and amendment regimes in different soil types. Eur J Plant Pathol 119:367-381. doi:10.1007/s10658-007-9167-z

Michel VV, Mew TW (1998) Effect of a soil amendment on the survival of Ralstonia solanacearum in different soils. Phytopathology 88:300-305

Milic V, Bogdanovic M, Uric M, Kovacevic D, Crnogorac M (2006) Influence of mineral nutrition and additional space upon yield of potato. Agroznanje Agroknowledge J 7:67-74

Milosevic D, Alovic I (2006) Some most important potato diseases and their control. Radovi Poljoprivrednog Fakulteta Univerziteta $\mathrm{u}$ Sarajevu (Works of the Faculty of Agriculture University of Sarajevo) 51:103-120

Milosevic D, Alovic I, Civic H (2005) Effect of some soil reclamation measures on the disease severity in potato tubers caused by common scab (Streptomyces scabies Thaxt.). Radovi Poljoprivrednog Fakulteta Univerziteta u Sarajevu (Works of the Faculty of Agriculture University of Sarajevo) 50, pp 33-42

Minnis ST, Haydock PPJ, Evans K (2004) Control of potato cyst nematodes and economic benefits of application of 1,3dichloropropene and granular nematicides. Ann Appl Biol 145:145-156

Mizuno N, Nizamidin K, Nanzyo M, Yoshida H, Amano Y (2003) Judging conducive soils from clay mineralogical properties and soil chemical method to suppress potato common scab. Soil Microorganisms 57:97-103

Moffett ML, Wood BA (1984) Survival of Corynebacterium michiganense subsp. michiganense within host debris in soil. Australas Plant Pathol 13:1-3

Mohsin M, Mian IH, Zahid MI, Ali M (1989) Inoculum level of Meloidogyne incognita on severity of root knot and growth of jute and potato. Bangladesh J Plant Pathol 5:13-17

Mol L, Scholte K (1995) Formation of microsclerotia of Verticillium dahliae Kleb on various plant parts of 2 potato cultivars. Potato Res 38:143-150

Molendijk LPG (1999) Control strategy for nematodes works ([example of] Vredepeel). PAV-Bulletin Akkerbouw, 4-8

Mordue JEM (1988) Thecaphora solani. IMI Descriptions of Fungi and Bacteria, Sheet 966

Moxnes JF, Hausken K (2007) The population dynamics of potato cyst nematodes. Ecol Modell 207:339-348. doi:10.1016/j. ecolmodel.2007.06.020

Mugniéry D (2007) The canon of potato science: 15 . root-knot nematodes. Potato Res 50:263-265. doi:10.1007/s11540-008-9048-7

Mugniéry D, Phillips MS (2007) The nematode parasites of potato. In: Vreugdenhil D, Bradshaw JE (eds) Potato biology and biotechnology. Elsevier, New York

Muhammad Z (1996) The effects of storage conditions on subsequent hatching of Globodera pallida (Nematoda: Tylenchida). Pedobiologia 40:342-351

Mulder A, Turkensteen LJ, Delleman J (eds) (2008) Aardappel ziektenboek: ziekten, plagen en beschadigingen. Aardappelwereld, Den Haag (Netherlands)
Mulder A, Van der Wal AF, Velema RAJ, Roosjen JS (1997) Effects of soil characteristics on the relationship between potato cyst nematodes and yield. II. Acidity (soil pH). Potato Res 40:375381

Muller P, Abdel-Kader D, Kakau J, Pastrik KH, Seigner L (2004) Survival of Ralstonia solanacearum biovar 2 (race 3), the causal agent of potato brown rot, in soil and on several kinds of materials (microcosm). Gesunde Pflanzen 56:129-141

Munzert M, Duben J, Langerfeld E (1977) On the influence of fungal and bacterial tuber rot pathogens on emergence diseases in the potato crop. Nachrichtenblatt Dtsch Pflanzenschutzdienstes 29:69-74

Muthukrishnan K, Raguchander T, Arjunan G (1995) Factors affecting survival of Macrophomina phaseolina in soil. Indian J Pulses Res 8:156-161

Nagesh M (1996) Relationship between the population densities of root-knot nematode, Meloidogyne incognita (Kofoid and White 1919) Chitwood 1949 and growth of potato, Solanum tuberosum L. Pest Manage Horticultural Ecosyst 2:9-14

Nakayama T (2007) Spongospora subterranea soil contamination and its relationship to severity of powdery scab on potatoes. J Gen Plant Pathol 73:229-234

Nakayama T, Merz U, Nakagawa A, Takehara T, Shimanuki T (2003) Differences in zoosporangial root infection of some potato varieties inoculated with Japanese and foreign field isolates of Spongospora subterranea f. sp. subterranea, Proceedings of the Fifth Symposium of the International Working Group on Plant Viruses with Fungal Vectors, Institute of Plant Sciences, Swiss Federal Institute of Technology, Zurich, Switzerland, 22-25 July, 2002, pp 115-118

Naumann K, Ficke W, Muller HJ, Skadow K, Zielke R (1974) Transmission of potato black leg and tuber soft rot (Pectobacterium carotovorum var. atrosepticum (van Hall) Dowson) by soil, seed material and soil cultivation. Arch Phytopathologie Pflanzenschutz 10:301-316

Nelson GA (1982) Corynebacterium sepedonicum in potato: effect of inoculum concentration on ring rot symptoms and latent infection. Can J Plant Pathol 4:129-133

Nelson GA (1984) Survival of Corynebacterium sepedonicum in potato stems and on surfaces held at freezing and above-freezing temperatures. Am Potato J 62:23-28

Nicot PC, Rouse DI (1987) Relationship between soil inoculum density of Verticillium dahliae and systemic colonization of potato stems in commercial fields over time. Phytopathology 77:1346-1355

Nissinen R (2000) Gram positive phytopathogenic bacterium Clavibacter michiganensis subsp. sepedonicus: Virulence factors and interactions with plants. Ann Univ Turkuensis A II Biol Geogr Geol 140:1-53

Nitzan N, Cummings TF, Johnson DA (2008) Disease potential of soil- and tuberborne inocula of Colletotrichum coccodes and black dot severity on potato. Plant Dis 92:1497-1502. doi:10.1094/pdis-92-11-1497

Nitzan N, Evans MA, Cummings TF, Johnson DA, Batchelor DL, Olsen C, Haynes KG, Brown CR (2009) Field resistance to potato stem colonization by the black dot pathogen Colletotrichum coccodes. Plant Dis 93:1116-1122. doi:10.1094/pdis-93-11-1116

Nitzan N, Tsror L (2003) Effect of temperature and $\mathrm{pH}$ on in vitro growth rate and sclerotial density of Colletotrichum coccodes isolates from different VCGs. Am J Potato Res 80:335-339

Nitzan N, Tsror L, Johnson DA (2006) Vegetative compatibility groups and aggressiveness of North American isolates of Colletotrichum coccodes, the causal agent of potato black dot. Plant Dis 90:1287-1292. doi:10.1094/pd-90-1287

Nouri S, Bahar M, Fegan M (2009) Diversity of Ralstonia solanacearum causing potato bacterial wilt in Iran and the first 
record of phylotype II/biovar $2 \mathrm{~T}$ strains outside South America. Plant Pathol 58:243-249. doi:10.1111/j.1365-3059.2008.01944.x

Nunes JCS, Fontes PCR, Araujo EF, Sediyama C (2006) Potato plant growth and macronutrient uptake as affected by soil tillage and irrigation systems. Pesqui Agropecuaria Bras 41:1787-1792

Nunez-Camargo MdC, Carrion G, Nunez-Sanchez AE (2003) Fungi associated with Globodera rostochiensis cysts in Mexico. Int $\mathrm{J}$ Nematology 13:151-161

Ocamb CM, Hamm PB, Johnson DA (2007) Benzimidazole resistance of Fusarium species recovered from potatoes with dry rot from storages located in the Columbia basin of Oregon and Washington. Am J Potato Res 84:169-177

Ochiai N, Powelson ML, Crowe FJ, Dick RP (2008) Green manure effects on soil quality in relation to suppression of Verticillium wilt of potatoes. Biol Fertil Soils 44:1013-1023. doi:10.1007/ s00374-008-0289-z

Ohazurike NC, Arinze AE (1992) The action of polygalacturonase enzyme of Sclerotium rolfsii on some tuber crop tissues. Fitopatologia Bras 17:393-398

Olivieri FP, Maldonado S, Tonon CV, Casalongue CA (2004) Hydrolytic activities of Fusarium solani and Fusarium solani $\mathrm{f}$. sp eumartii associated with the infection process of potato tubers. J Phytopathol 152:337-344

Olsen NL, Kleinkopf GE, Woodell LK (2003) Efficacy of chlorine dioxide for disease control on stored potatoes. Am J Potato Res 80:387-395

Okopnyi NS, Mavlyanov OM, Narbaev Z.N (1983) Mechanisms of resistance to rootknot nematodes in cotton. Uzbekskii Biologicheskii Zhurnal 6:45-47

Omer MA, Johnson DA, Douhan LI, Hamm PB, Rowe RC (2008) Detection, quantification, and vegetative compatibility of Verticillium dahliae in potato and mint production soils in the Columbia Basin of Oregon and Washington. Plant Dis 92:1127-1131. doi:10.1094/pdis-92-7-1127

Ostergaard SP, Henriksen JB (1983) Potato tuber rot after lifting at different soil temperatures. Tidsskr Planteavl 87:111-117

Ouellette E, Raghavan GSV, Reeleder RD, Greenhalgh R (1990) Volatile monitoring technique for disease detection in stored potatoes. J Food Process Preserv 14:279-300

Ozarslandan A, Devran Z, Mutlu N, Elekcioglu IH (2009) First report of columbia root-knot nematode (Meloidogyne chitwoodi) in potato in Turkey. Plant Disease. doi:10.1094/pdis-93-3-0316c

Paillotin G (2008) Ecophyto 2018. Ministère de l'agriculture et de la pêche, Paris, p 142

Palomo JL, Velazquez E, Mateos PF, Garcia-Benavides P, MartinezMolina E (2000) Rapid identification of Clavibacter michiganensis subspecies sepedonicus based on the stable low molecular weight RNA (LMW RNA) profiles. Eur J Plant Pathol 106:789-793

Pandey RC, Dwivedi BK, Singh SP (2002) Effect of soil moisture and hydrogen ion concentration on population dynamics of Meloidogyne incognita at Allahabad. Curr Nematology 13:57-60

Panique E, Kelling KA, Schulte EE, Hero DE, Stevenson WR, James RV (1997) Potassium rate and source effects on potato yield, quality, and disease interaction. Am Potato J 74:379-398

Panka D, Sadowski C, Rolbiecki S (2007) Influence of micro irrigation on health status of chosen potato cultivars grown in very light soil. Proceedings of the IIIrd Balkan Symposium on Vegetable and Potatoes, 357-360

Papert A, Kok CJ, van Elsas JD (2004) Physiological and DNA fingerprinting of the bacterial community of Meloidogyne fallax egg masses. Soil Biol Biochem 36:1843-1849. doi:10.1016/j. soilbio.2004.04.038

Park EJ, Lee SD, Chung EJ, Lee MH, Um HY, Murugaiyan S, Moon BJ, Lee SW (2007) MicroTom - a model plant system to study bacterial wilt by Ralstonia solanacearum. Plant Pathol J 23:239-244
Park Y, Kang H, Been C, Choi Y, Choi Y (2002) Chemical control of potato common scab (Streptomyces scabies). Korean J Horticultural Sci Technol 20:319-324

Pasco C, Jouan B, Andrivon D (2005) Resistance of potato genotypes to common and netted scab-causing species of Streptomyces. Plant Pathol 54:383-392. doi:10.1111/j.1365-3059.2005.01178.x

Pelsmaeker Md, Coomans A (1987) Nematodes in potato fields and the relation to some biotic and abiotic factors. Mededelingen van de Faculteit Landbouwwetenschappen, Rijksuniversiteit Gent 52:561-569

Perez EE, Weingartner DP, McSorley R (2000) Correlation between Paratrichodorus minor population levels and corky ringspot symptoms on potato. Nematropica 30:247-251

Perez W, Gutarra L, French E (1994) Pythium ultimum Trow. causing watery rot in potato tubers in Peru. Fitopatologia 29:191-195

Perez W, Torres H (2008) Potato smut, Thecaphora solani. In: Elsevier (ed) Diseases, pests and disorders of potatoes Wale, Stuart., Platt, Bud., Platt, Harold William., Cattlin, Nigel D., pp. 66-68. ISBN 0123736706, 9780123736703

Perombelon MCM (2000) Blackleg risk potential of seed potatoes determined by quantification of tuber contamination by the causal agent and Erwinia carotovora subsp. atroseptica: a critical review. Bulletin OEPP 30

Perombelon MCM, Gullingshandley J, Kelman A (1979) Population dynamics of Erwinia carotovora and pectolytic Clostridium spp. in relation to decay of potatoes. Phytopathology 69:167-173

Peters JC, Lees AK, Cullen DW, Sullivan L, Stroud GP, Cunnington AC (2008a) Characterization of Fusarium spp. responsible for causing dry rot of potato in Great Britain. Plant Pathol 57:262-271

Peters RD, Clark RJ, Coffin AD, Sturz AV, Lambert DH, Miller JS (2005) Limited genetic diversity in North American isolates of Phytophthora erythroseptica pathogenic to potato based on RAPD analysis. Plant Dis 89:380-384. doi:10.1094/pd-89-0380

Peters RD, MacLeod C, Seifert KA, Martin RA, Hale LR, Grau CR, MacInnis S (2008b) Pathogenicity to potato tubers of Fusarium spp. isolated from potato, cereal and forage crops. Am J Potato Res 85:367-374. doi:10.1007/s12230-008-9037-z

Peters RD, Sturz AV, Carter MR, Sanderson JB (2003) Developing disease-suppressive soils through crop rotation and tillage management practices. Soil Tillage Res 72:181-192

Peters RD, Sturz AV, Carter MR, Sanderson JB (2004) Influence of crop rotation and conservation tillage practices on the severity of soil-borne potato diseases in temperate humid agriculture. Can J Soil Sci 84:397-402

Philis J (1997) Effect of cadusafos and carbofuran against Pratylenchus penetrans and some ectoparasitic nematodes infesting potato in Cyprus. Nematologia Mediterr 25:169-172

Phillips AJL (1989) Fungi associated with sclerotia of Sclerotinia sclerotinium in South Africa and their effects on the pathogen. Phytophylactica 21:135-140

Pitman AR, Wright PJ, Galbraith MD, Harrow SA (2008) Biochemical and genetic diversity of pectolytic enterobacteria causing soft rot disease of potatoes in New Zealand. Australas Plant Pathol 37:559-568. doi:10.1071/ap08056

Platt HW, Mahuku G (2000) Detection methods for Verticillium species in naturally infested and inoculated soils. Am J Potato Res 77:271-274

Povolny P (1995) Influence of exposure to light and cultivation system on resitance to Phoma foveata and Fusarium solani var. coeruleum in potato tubers - a pilot study. Swed J Agric Res $25: 47-50$

Prescott L, Harley JP, Klein DA, Bacq-Calberg C-M, Dusart J (2003) La classe des Clostridia. In: Prescott L, Harley JP, Klein DA, BacqCalberg C-M, Dusart J (eds) Microbiologie, De Boeck, pp 523-525

Prithiviraj B, Sarma BK, Srivastava JS, Singh UP (2000) Effect of $\mathrm{Ca} 2+, \mathrm{Mg} 2+$, light, temperature and $\mathrm{pH}$ on athelial stage 
formation in Sclerotium rolfsii Sacc. Z Fur Pflanzenkrankheiten Und Pflanzenschutz J Plant Dis Prot 107:274-278

Pudasaini MP, Viaene N, Moens M (2007) The influence of host and temperature on the vertical migration of Pratylenchus penetrans. Nematology 9:437-447

Pylypenko LA, Phillips MS, Blok VC (2008) Characterisation of two Ukrainian populations of Globodera pallida in terms of their virulence and mtDNA, and the biological assessment of a new resistant cultivar Vales Everest. Nematology 10:585-590

Qian Z, Ma C, Gu Z, Qian G, Zhang F, He C, Gu A (1996) Biology, identification and control of root knot nematode Meloidogyne hapla on Aconitum carmichaeli. Acta Agriculturae Shanghai 12:81-86

Qu XS, Kavanagh JA, Egan D, Christ BJ (2006) Detection and quantification of Spongospora subterranea $\mathrm{f}$. sp subterranea by PCR in host tissue and naturally infested soils. Am J Potato Res 83:21-30

Rahman ML, Hossain MM, Ashrafuzzaman M, Islam T (1996) Effect of inoculum levels of Rhizoctonia solani on the incidence of black scurf disease of potato. Bangladesh J Plant Pathol 12:21-22

Rangaswami G, Mahadevan A (2004) Disease of crop plants in India. Fourth Edition, ISBN: 978-81-203-1247-0, p 548

Raviv M (2008) The use of compost in growing media as suppressive agent against soil-borne diseases. Proceedings of the International Symposium on Growing Media, 39-49

Ray H, Hammerschmidt R (1998) Responses of potato tuber to infection by Fusarium sambucinum. Physiol Mol Plant Pathol 53:81-92

Recep K, Fikrettin S, Erkol D, Cafer E (2009) Biological control of the potato dry rot caused by Fusarium species using PGPR strains. Biol Control 50:194-198. doi:10.1016/j.biocontrol.2009.04.004

Rehman S, Butterbach P, Popeijus H, Overmars H, Davis EL, Jones JT, Goverse A, Bakker J, Smant G (2009) Identification and characterization of the most abundant cellulases in stylet secretions from Globodera rostochiensis. Phytopathology 99:194-202. doi:10.1094/phyto-98-2-0194

Reid A (2009) PCR detection of potato cyst nematode. Meth Mol Biol. doi:10.1007/978-1-59745-062-1_22

Repsiene R, Mineikiene EV (2006) The influence of meteorological conditions and different agricultural systems on the spreading of potato cv. 'Mirta' tuber diseases and their yield. Zemes ukio Mokslai, 16-25

Riga E, Karanastasi E, Oliveira CMG, Neilson R (2007) Molecular identification of Two stubby root nematode species. Am J Potato Res 84:161-167

Riga E, Neilson R (2005) First report of the stubby-root nematode, Paratrichodorus teres, from potato in the Columbia basin of Washington State. Plant Dis 89:1361-1361

Rivera-Varas VV, Freeman TA, Gudmestad NC, Secor GA (2007) Mycoparasitism of Helminthosporium solani by Acremonium strictum. Phytopathology 97:1331-1337. doi:10.1094/phyto-97-10-1331

Robbins RT, Barker KR (1974) Effects of soil type, particle size, temperature, and moisture on reproduction of Belonolaimus longicaudatus. J Nematology 6:1-6

Rojancovschi E (1994) Researches concerning the effectiveness of some pesticides for the protection of potato crop against the potato rot nematode, Ditylenchus destructor Thorne. BPP, Buletinul de Protectia Plantelor, 29-31

Ronda BHNAM, van Beuningen AR, Gorkink RFJ, Zwaardemaker NG, Janse JD (1999) Evaluation of a PCR for detection of Ralstonia (Pseudomonas) solanacearum (race 3, biovar 2) and Clavibacter michiganensis subsp. sepedonicus and comparison with immuno-fluorescence microscopy, plating on semiselective SMSA medium, pathogenicity test and fluorescent in-situ hybridisation. Mededelingen Faculteit Landbouwkundige en Toegepaste Biologische Wetenschappen Universiteit Gent 64:583-591
Rotenberg D, MacGuidwin AE, Saeed IAM, Rouse DI (2004) Interaction of spatially separated Pratylenchus penetrans and Verticillium dahliae on potato measured by impaired photosynthesis. Plant Pathol 53:294-302. doi:10.1111/j.1365-3059.2004.01005.x

Rousselle P, Robert Y, Crosnier J-C (eds) (1996) La pomme de terre: Production, amélioration, ennemis et maladies, utilisations, Paris

Rudkiewicz F, Sikorski J (1984) Effect of the incidence of common scab (Streptomyces spp.) on seed potatoes on plant growth and tuber yield. Biuletyn Instytutu Ziemniaka, 129-138

Rudkiewicz F, Sikorski J, Slazak J (1983) Effect of the soil type, fertilization and control of Phytophthora infestans on the development of some diseases of potato plants and tubers. Biuletyn Instytutu Ziemniaka, 157-170

Ruijter FJd, Haverkort AJ (1999) Effects of potato-cyst nematodes (Globodera pallida) and soil $\mathrm{pH}$ on root growth, nutrient uptake and crop growth of potato. Eur J Plant Pathol 105:61-76. doi:10.1023/a:1008641511688

Ryan NA, Deliopoulos T, Jones P, Haydock PPJ (2003) Effects of a mixed-isolate mycorrhizal inoculum on the potato-potato cyst nematode interaction. Ann Appl Biol 143:111-119

Ryan NA, Jones PW (2003) Effect of tuber-borne micro-organisms on hatching activity of potato root leachate towards potato cyst nematodes. Nematology 5:55-63

Saeed IAM, Macguidwin AE, Rouse DI (1998) Effect of initial nematode population density on the interaction of Pratylenchus penetrans and Verticillium dahliae on 'Russet burbank' potato. J Nematology 30:100-107

Sahajdak A, Uznanska B (2003) Potato health requirements arising from EU regulations and the Treaty of Accession. Ochrona Roslin 47:20-23

Salas B, Secor GA, Taylor RJ, Gladmestad NC (2003) Assessment of resistance of tubers of potato cultivars to Phytophthora erythroseptica and Pythium ultimum. Plant Dis 87:91-97

Salas B, Stack RW, Secor GA, Gudmestad NC (2000) The effect of wounding, temperature, and inoculum on the development of pink rot of potatoes caused by Phytophthora erythroseptica. Plant Dis 84:1327-1333

Saleh OI, Huang JS (1997) Bacterial soft rot disease of tomato fruits in Florida, USA: identification, response of some American and Egyptian cultivars of solanaceous plants and chemical control. Assiut J Agric Sci 28:11-26

Samaliev H, Andreev R (1998) Relationship between initial population density of potato cyst nematode Globodera pallida Thorne and the yield of partially resistant potato varieties. Bulgarian J Agric Sci 4:421-427

Samaliev H, Grigorov P, Samalieva A (1998) Influence of population density of Globodera rostochiensis (Nematoda: Heteroderidae) on potato yield. Rasteniev"dni Nauki 35:235-238

Sankaranarayanan C, Sundarababu R (2001) Influence of moisture and $\mathrm{pH}$ on the efficiency of VA-mycorrhiza, Glomus mosseae (Nicol and Gerd.) Gerd. and Trappe against Meloidogyne incognita (Kofoid and White) Chitw. on blackgram (Vigna mungo L.) Hepper. J Biol Control 15:69-72

Santamarina MP, Rosello J (2006) Influence of temperature and water activity on the antagonism of Trichoderma harzianum to Verticillium and Rhizoctonia. Crop Prot 25:1130-1134. doi:10.1016/j.cropro.2006.02.006

Savary S, Teng PS, Willocquet L, Nutter FW (2006) Quantification and modeling of crop losses: a review of purposes. Annu Rev Phytopathol 44:89-112. doi:10.1146/annurev. phyto.44.070505.143342

Scheid L (2006) What to do against storage diseases? Kartoffelbau, $362-365$

Schena L, Nigro F, Ippolito A (2002) Identification and detection of Rosellinia necatrix by conventional and real-time Scorpion-PCR. Eur J Plant Pathol 108:355-366 
Schisler DA, Slininger PJ, Miller JS, Woodell LK, Clayson S, Olsen N (2009) Bacterial antagonists, zoospore inoculum retention time and potato cultivar influence pink rot disease development. Am J Potato Res 86:102-111. doi:10.1007/s12230-008-9066-7

Scholte K (2000) Effect of potato used as a trap crop on potato cyst nematodes and other soil pathogens and on the growth of a subsequent main potato crop. Ann Appl Biol 136:229-238

Scholte K (2005) Netted scab In: Delleman J, Mulder A, Peeten JMG, Schippers B, Turkensteen LJ (eds) Potato diseases. Diseases, pests and defects, NIVAP Holland, Aardappelwereld magazine, pp 83-84

Scholte K, S'Jacob JJ (1989) Synergistic interactions between Rhizoctonia solani Kuhn, Verticillium dahliae Kleb., Meloidogyne spp. and Pratylenchus neglectus (Rensch) Chitwood \& Oteifa, in potato. Potato Res 32:387-395

Secor GA, Debuhr L, Gudmestad NC (1988) Susceptibility of Corynebacterium sepedonicum to disinfectants in vitro. Plant Dis $72: 585-588$

Sepulveda RP, Lopez TH, Nunez LD (2000) Effect of different soil humidity on the development of potato smut (Angiosorus solani) in two potato varieties (Solanum tuberosum) under greenhouse conditions. Agricultura Tec 60:313-319

Serfontein S, Logan C, Swanepoel AE, Boelema BH, Theron DJ (1991) A potato wilt disease in South Africa caused by Erwinia carotovora subspecies carotovora and Erwinia chrysanthemi. Plant Pathol 40:382-386

Sharifi K, Zare R, Rees-George J (2008) Vegetative compatibility groups among Fusarium solani isolates causing potato dry rot. J Biol Sci 8:374-379

Shcolnick S, Dinoor A, Tsror L (2007) Additional vegetative compatibility groups in Colletotrichum coccodes subpopulations from Europe and Israel. Plant Dis 91:805-808. doi:10.1094/pdis-91-7-0805

Shekhawat GS, Perombelon MCM (1991) Factors affecting survival in soil and virulence of Pseudomonas solanacearum. Z Fur Pflanzenkrankheiten Und Pflanzenschutz J Plant Dis Prot 98:258-267

Sheoraj S, Prajapati RK, Srivastava SSL, Pandey RK (2007) Influence of soil texture, temperature and relative humidity on development of collar rot of lentil. Indian Phytopathol 60:273-274

Shojaei M, Karegar A, Deljoo A (2006) Aspects of biology of, and responses of several potato cultivars to, potato rot nematode. Iran J Plant Pathol 42:Pe577-Pe595, en165-en168

Sikka LC, Singh AK (1976) Factors influencing quality of ware potatoes. J Indian Potato Assoc 3:24-28

Singh RDN, Kaiser SAKM (1994) Effect of different culture media and $\mathrm{pH}$ levels on growth and cultural characteristics of charcoal rot pathogen (Macrophomina phaseolina) infecting maize. Crop Res Hisar 7:282-287

Slack SA, Westra AAG (1998) Evaluation of flusulfamide for the control of bacterial ring rot of potato. Am J Potato Res 75:225230

Smith DS, De Boer SH (2009) Implementation of an artificial reaction control in a TaqMan method for PCR detection of Ralstonia solanacearum race 3 biovar 2. Eur J Plant Pathol 124:405-412. doi:10.1007/s10658-008-9427-6

Smith NC, Hennessy J, Stead DE (2001) Repetitive sequence-derived PCR profiling using the BOX-A1R primer for rapid identification of the plant pathogen Clavibacter michiganensis subspecies sepedonicus. Eur J Plant Pathol 107:739-748

Soltani N, Conn KL, Abbasi PA, Lazarovits G (2002) Reduction of potato scab and Verticillium wilt with ammonium lignosulfonate soil amendment in four Ontario potato fields. Can J Plant Pathol Rev Can De Phytopathologie 24:332-339

Solunke BS, Kareppa BM, Gangawane LV (2001) Survival ability of carbendazim resistant Sclerotium rolfsii in mixed population. Indian Phytopathol 54:486-487

Somani AK, Chauhan RKS (1996) Potato tuber rots in Gwalior, Madhya Pradesh. J Indian Potato Assoc 23:144-148
Spaull VW, Cadet P (2001) Nematodes and nutrients: association between plant-parasitic nematodes and soil chemicals. Proceedings of the Annual Congress-South African Sugar Technologists' Association, 116-117

Stachewicz VH, Enzian S (1998) Do temperature and rainfall limit the occurrence of potato wart in Germany? Nachrichtenblatt Dtsch Pflanzenschutzdienstes 50:105-111

Stamps DJ (1978) Phytophthora erythroseptica. IMI Descriptions of Fungi and Bacteria, Sheet 593

Steinberg C, Edel-Hermann V, Alabouvette C, Lemanceau P (2007) Soil suppressiveness to plant diseases. In: van Elsas JD, Jansson J, Trevors JT (eds) Modern soil microbiology. CRC, New York, pp 455-478

Stevenson WR, Loria R, Franc GD, Weingartner DP (2001) Compendium of potato diseases. The American Phytopathological Society, St. Paul, MN, USA

Strausbaugh CA, Schroth MN, Weinhold AR, Hancock JG (1992) Assessment of vegetative compatibility of Verticillium dahliae tester strains and isolates from California potatoes. Phytopathology 82:61-68

Sunaina V, Kishore V, Shekhawat GS, Kumar M (2000) Persistence of Ralstonia solanacearum in naturally infested soil under changing environment. Potato, Global Research \& Development. Proceedings of the Global Conference on Potato, New Delhi, India, 6-11 December, 1999: vol 1, pp 444-447

Suyama K, Tjahjono B, Fujii H (1990) Occurence of slimy rot disease on the stored potato tubers. Ann Phytopathological Soc Jpn $56: 577-583$

Taylor RJ (2005) Influence of tillage and method of metam sodium application on distribution and survival of Verticillium dahliae in the soil and the development of Verticillium wilt of potato. Am J Potato Res 82:451-461

Taylor RJ, Pasche JS, Gudmestad NC (2006) Biological significance of mefenoxam resistance in Phytophthora erythroseptica and its implications for the management of pink rot of potato. Plant Dis 90:927-934. doi:10.1094/pd-90-0927

Taylor RJ, Pasche JS, Gudmestad NC (2008) Susceptibility of eight potato cultivars to tuber infection by Phytophthora erythroseptica and Pythium ultimum and its relationship to mefenoxammediated control of pink rot and leak. Ann Appl Biol 152:189199. doi:10.1111/j.1744-7348.2007.00203.x

Taylor RJ, Salas B, Gudmestad NC (2004) Differences in etiology affect mefenoxam efficacy and the control of pink rot and leak tuber diseases of potato. Plant Dis 88:301-307

Ten Hoopen GM, Krauss U (2006) Biology and control of Rosellinia bunodes, Rosellinia necatrix and Rosellinia pepo: a review. Crop Prot 25:89-107

Termorshuizen AJ, van Rijn E, van der Gaag DJ, Alabouvette C, Chen Y, Lagerlof J, Malandrakis AA, Paplomatas EJ, Ramert B, Ryckeboer J, Steinberg C, Zmora-Nahum S (2006) Suppressiveness of 18 composts against 7 pathosystems: variability in pathogen response. Soil Biol Biochem 38:2461-2477. doi:10.1016/j.soilbio.2006.03.002

Thompson AL, Taylor RJ, Pasche JS, Novy RG, Gudmestad NC (2007) Resistance to Phytophthora erythroseptica and Pythium ultimum in a potato clone derived from $S$-berthaultii and $S$ etuberosum. Am J Potato Res 84:149-160

Tivoli B (1983) Action of temperature and humidity on the behavior in soil of 3 Fusarium species or varieties causing dry-rot in potato-tubers. Agronomie 3:1001-1009

Tivoli B, Corbiere R, Lemarchand E (1990) Relations between the $\mathrm{Ph}$ of soils and their level of conduciveness to Fusarium solani var Coeruleum and Fusarium roseum var sambucinum responsible for the dry rot of potato-tubers. Agronomie 10:63-68

Tivoli B, Tika N, Lemarchand E (1987) Observations on the conduciveness of soils to fungi causing dry rot of potato-tubers-Fusarium 
solani var. coeruleum, F. roseum var. sambucinum and Phoma exigua var. foveata. Agronomie 7:531-538

Tomlinson DT, Elphinstone JG, El-Fatah HA, Agag SHA, Kamal M, Soliman MY, El-Aliem MMA, El-Ghany HA, El-Haddad SA, Fawzi FG, Janse JD (2005) Survival of the potato brown rot bacterium (Ralstonia solanacearum biovar 2) in Egyptian soils. Potato in Progress: Science Meets Practice, 233-238

Trifonova Z (1997) Effect of population density on cyst production of Globodera rostochiensis Woll. 1923. Bulgarian Journal of Agricultural Science 3:755-758

Trifonova Z (1923) (2001) Effect of inorganic fertilizers and soil type on the growth of potato and reproduction of Globodera rostochiensis Woll. Macedonian Agric Rev 48:57-60

Triki MA, Priou S, El MM, Baudry A (2001) Leak syndrome of potato in Tunisia caused by Pythium aphanidermatum and Pythium ultimum. Potato Res 44:221-231

Tsror L (2004) Effect of light duration on severity of black dot caused by Colletotrichum coccodes on potato, Plant Pathology 53, 288293

Tsror L, Erlich O, Cahlon Y, Hadar A, Cohen Y, Klein L, Peretz-Alon I (2000) Control of Verticiilium dahliae prior to potato production by soil fumigation with chloropicrin. Proceedings of the International Symposium on Chemical and Non-Chemical Soil and Substrate Disinfestation, 201-204

Tsror L, Nachmias A, Erlich O, Aharon M, Perombelon MCM (1993) A 9-year monitoring study of diseases on potato seed tubers imported to Israel. Phytoparasitica 21:321-328

Tsror L, Peretz-Alon I (2005) The influence of the inoculum source of Rhizoctonia solani on development of black scurf on potato. J Phytopathol 153:240-244

Tsror L, Shlevin E, Peretz-Alon I (2005) Efficacy of metam sodium for controlling Verticillium dahliae prior to potato production in sandy soils. Am J Potato Res 82:419-423

UNECE (2010) Working party on agricultural quality standards. Available from: http://www.unece.org/trade/agr/. Accessed on 15 April 2010.

Vallad GE, Qin QM, Subbarao KV (2004) Verticillium wilt of cool season vegetable crops: their distribution, impact and management. Recent research developments in plant pathology 3:189-210

Vanvuurde JWL, Devries PM (1994) Population dynamics of Erwinia carotovora subsp. atroseptica on the surface of intact and wounded seed potatoes during storage. J Appl Bacteriol 76:568-575

Vasinauskiene M, Baranauskaite L (2003) Occurrence of Clavibacter michiganensis subsp. sepedonicus in Lithuania. Zemes ukio Mokslai, 30-33

Vian J (2009) Comparaison de différentes techniques de travail du sol en agriculture biologique: effet de la structure et de la localisation des résidus sur les microorganismes du sol et leurs activités de minéralisation du carbone et de l'azote. Institut des Sciences et Industries du Vivant et de l'Environnement (Agro Paris Tech). Agro Paris Tech, Paris, p 130

Vico I, Krstic B, Stojanovic G (1997) The occurrence of Polyscytalum pustulans on potatoes in Yugoslavia. Acta Horticulturae 462:339-343

Vishwa D, Sarbhoy AK (1989) Studies on the germination and longevity of pycnidiospores of Macrophomina phaseolina. Indian Phytopathol 42:123-127

Vivoda E, Davis RM, Nunez JJ, Guerard JP (1991) Factors affecting the development of cavity spot of carrot. Plant Dis 75:519-522

Volovik AS, Borisenok AV, Shuiskaya NG (1980) Agrotechniques in the control of diseases. Zashchita Rastenii, 26

Vovlas N, Mifsud D, Landa BB, Castillo P (2005) Pathogenicity of the root-knot nematode Meloidogyne javanica on potato. Plant Pathol 54:657-664. doi:10.1111/j.1365-3059.2005.01244.x

Vreugdenhil D (2007) Potato biology and biotechnology—advances and perspectives. Elsevier, Amsterdam
Vries PMd, Vuurde JWLv (1993) Survival of Erwinia carotovora ssp. atroseptica on seed potato. Gewasbescherming 24:103-108

Wale S, Platt HWB, Cattlin ND (2008) Diseases, pests and disorders of potatoes. Academic, London

Wang AX, Lazarovits G (2005) Role of seed tubers in the spread of plant pathogenic Streptomyces and initiating potato common scab disease. Am J Potato Res 82:221-230

Wanner LA (2007) High proportions of nonpathogenic Streptomyces are associated with common scab-resistant potato lines and less severe disease. Can J Microbiol 53:1062-1075. doi:10.1139/w07-061

Ward LI (2004) A real-time PCR assay based method for routine diagnosis of Spongospora subterranea on potato tubers. J Phytopathol 152:633-638

Wegener CB, Jansen G (2007) Soft-rot resistance of coloured potato cultivars (Solanum tuberosum L.): the role of anthocyanins. Potato Res 50:31-44. doi:10.1007/s11540-007-9027-4

Weller DM, Raaijmakers JM, Gardener BBM, Thomashow LS (2002) Microbial populations responsible for specific soil suppressiveness to plant pathogens. Ann Rev Phytopathol 40:309-+. doi:10.1146/annurev.phyto.40.030402.110010

Westra AAG, Arneson CP, Slack SA (1994) Effect of interaction of inoculum dose, cultivar, and geographic location on the development of foliar symptoms of bacterial ring rot of potato. Phytopathology 84:410-415

Wharton DA, Worland MR (2001) Water relations during desiccation of cysts of the potato-cyst nematode Globodera rostochiensis. J Comp Physiol B Biochem Syst Environ Physiol 171:121-126

Wharton PS, Kirk WW, Berry D, Tumbalam P (2007) Seed treatment application-timing options for control of Fusarium decay and sprout rot of cut seedpieces. Am J Potato Res 84:237-244

Wilson CR, Ransom LM, Pemberton BM (1999) The relative importance of seed-borne inoculum to common scab disease of potato and the efficacy of seed tuber and soil treatments for disease control. J Phytopathol Phytopathologische Z 147:13-18

Wilson PS, Ahvenniemi PM, Lehtonen MJ, Kukkonen M, Rita H, Valkonen JPT (2008) Biological and chemical control and their combined use to control different stages of the Rhizoctonia disease complex on potato through the growing season. Ann Appl Biol 153:307-320. doi:10.1111/j.1744-7348.2008.00292.x

Wolf JMvd, Beckhoven JRCMv (2004) Factors affecting survival of Clavibacter michiganensis subsp. sepedonicus in water. J Phytopathol 152:161-168. doi:10.1111/j.1439-0434.2004.00820.x

Wolf JMvd, Beckhoven JRCMv, Hukkanen A, Karjalainen R, Muller P (2005) Fate of Clavibacter michiganensis ssp. sepedonicus, the causal organism of bacterial ring rot of potato, in weeds and field crops. J Phytopathol 153:358-365. doi:10.1111/j.1439-0434.2005.00985.x

Woodhall JW, Lees AK, Edwards SG, Jenkinson P (2007) Characterization of Rhizoctonia solani from potato in Great Britain. Plant Pathol 56:286-295

Woodhall JW, Lees AK, Edwards SG, Jenkinson P (2008) Infection of potato by Rhizoctonia solani: effect of anastomosis group. Plant Pathol 57:897-905. doi:10.1111/j.1365-3059.2008.01889.x

Wronkowska H, Janowicz K (1989) Examination of Globodera rostochiensis cysts infected with strains of Fusarium oxysporum in vitro. Zesz Problemowe Postepow Nauk Rolniczych 358:57-61

Wu Q, Wang X, Liao J, Qin G, Li S (2006) Effect of light and temperature on culture of root-knot nematode on Solanum tuberosum. Plant Prot 32:27-29

Xu J, Zhou B, Liu Y, Li M, Li J (1997) Biological characteristics of Rhizoctonia solani Kuhnzheng. Plant Prot 23:29-30

Yaganza ES, Rioux D, Simard M, Arul J, Tweddell RJ (2004) Ultrastructural alterations of Erwinia carotovora subsp atroseptica caused by treatment with aluminum chloride and sodium metabisulfite. Appl Environ Microbiol 70:6800-6808. doi:10.1128/aem.70.11.6800-6808.2004 
Yang LP, Xie JT, Jiang DH, Fu YP, Li GQ, Lin FC (2008) Antifungal substances produced by Penicillium oxalicum strain PY-1potential antibiotics against plant pathogenic fungi. World J Microbiol Biotechnol 24:909-915. doi:10.1007/s11274-0079626-x

Yi Y, Sul K (1998) Control strategy of acidified nutrient solution on bacterial wilt of tomato plants. Korean J Plant Pathol 14:744-746

Young CS, Clarkson JP, Smith JA, Watling M, Phelps K, Whipps JM (2004) Environmental conditions influencing Sclerotinia sclerotiorum infection and disease development in lettuce. Plant Pathol 53:387-397. doi:10.1111/j.1365-3059.2004.01018

Zagoskina NV, Goncharuk EA, Dubravina GA Kalashnikova EA (2006) Effect of exometabolites of the fungus Rhizoctonia solani on the cell cultures of potato various genotypes. Biotekhnologiya 5:19-22
Zambolim L, Parizzi P, Matsuoka K, Xavier F, Vale RD, Chaves GM (1995) Powdery scab of potato. Fitopatologia Bras 20:5-12

Zhang Z, Chen R, Wang Y, Wang K, Zheng X (2005) Molecular detection of Verticillium albo-atrum by PCR based on its sequences. Agric Sci China 4:760-766

Zhao WQ, Liu DQ, Yu XM (2008) First report of potato scab caused by Streptomyces turgidiscabies in China. Plant Dis 92:1587. doi:10.1094/pdis-92-11-1587c

Zielke R, Muller HJ, Ficke W, Naumann K, Skadow K (1974) The effect of soil and climate on the occurrence of blackleg and tuber soft rot of potato, Archiv fur Phytopathologie und Pflanzenschutz $10: 245-253$

Zimny L, Wacawowicz R, Oliwa T (2006) Tuber infestation by Rhizoctonia solani in relation to cultivation systems of potato. Prog Plant Prot 46:388-394 